\title{
Sistema de Navegação para Robôs Móveis Baseado em Mapas Cognitivos
}

\author{
Fabio Roberto Melfi
}

Orientador: Prof. Dr. André Carlos Ponce de Leon Ferreira de Carvalho

Dissertação apresentada ao Instituto de Ciências Matemáticas e de Computação - ICMC-USP, como parte dos requisitos para obtenção do título de Mestre em Ciências - Área: Ciências de Computação e Matemática Computacional. 


\section{Agradecimentos}

Passei os três melhores anos da minha vida na USP, fazendo mestrado. Por isso, quero agradecer a todos os amigos que fiz, aos melhores professores (e pesquisadores) com quem já aprendi, aos funcionários e ao CNPq pelo muito apreciado apoio financeiro. Em especial, as seguintes pessoas:

Maria Carolina Monard, não tenho palavras para agradecer a tudo. OBRIGADO MESMO!

André Carlos Ponce de Leon Ferreira de Carvalho, o melhor professor e orientador que um aluno pode querer. Vai deixar saudades no Brasil. Obrigado por tudo.

Solange Oliveira Rezende, a alma do Labic e a quem admiro muito. Me sinto feliz por te conhecer. 


\section{Índice}

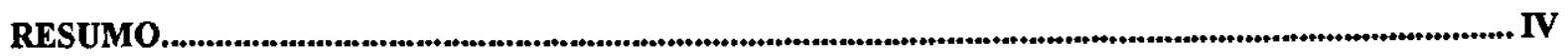

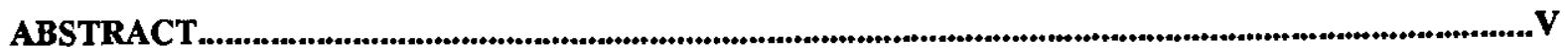

1.1 CONTEXTO

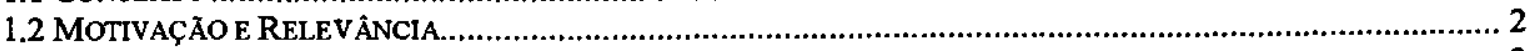

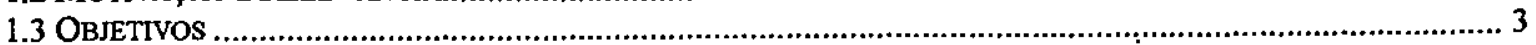

1.4 ORGANZAÇÃO DO TRABALHO

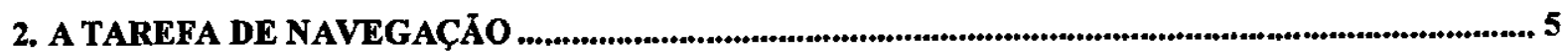

2.1 REQUISTIOS DE UM SISTEMA DE NAVEGAÇÃo ............................................................................. 5

2.2 ASPECTOS A SEREM TRATADOS.

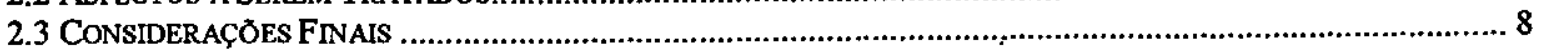

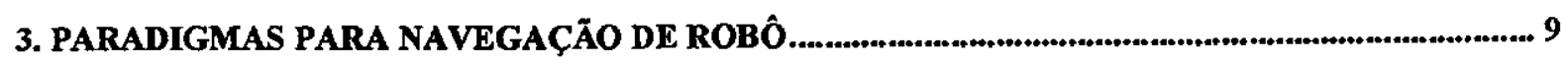

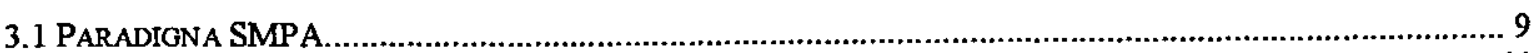

3.1.1. Mapeamento do Anbiente

3. I.2. Transformaçãa do Mapa Métrico em Mapa Topológico ................................................................12

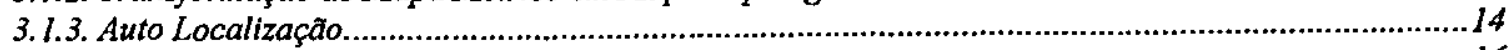

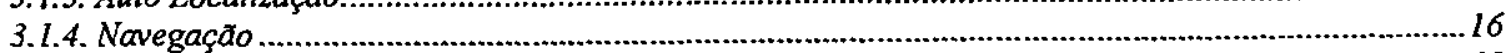

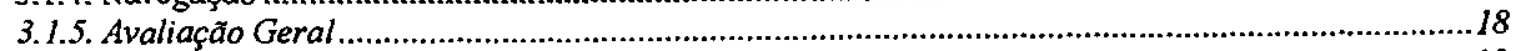

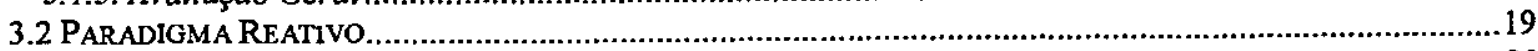

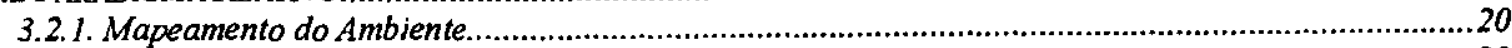

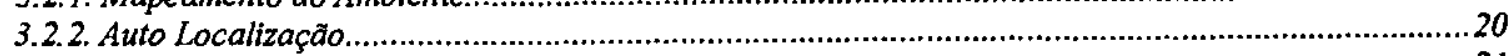

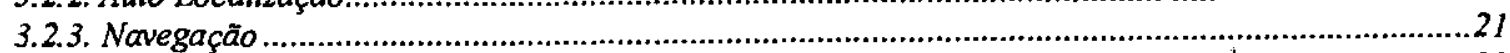

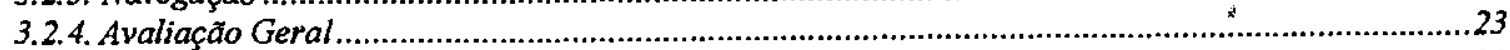

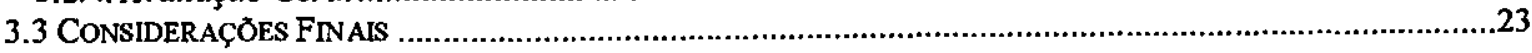

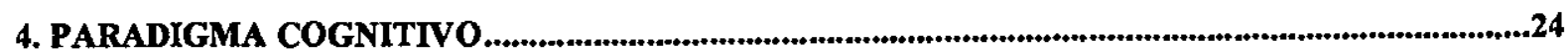

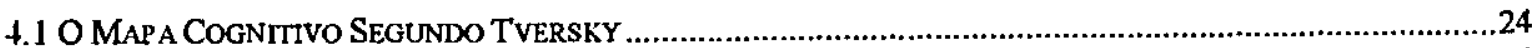

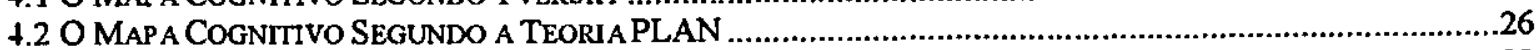

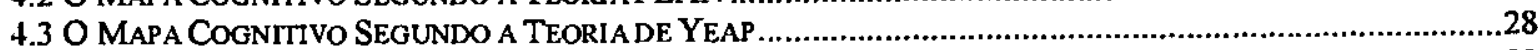

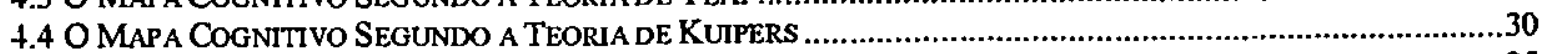

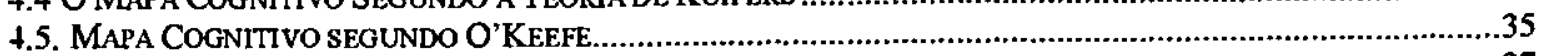

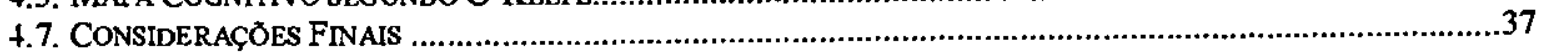

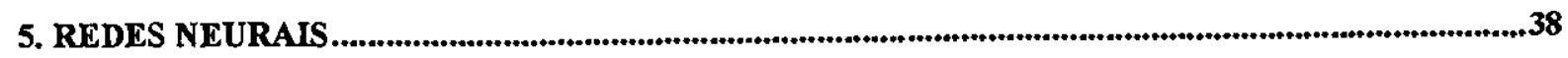

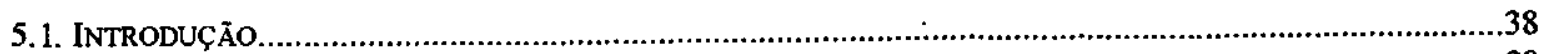

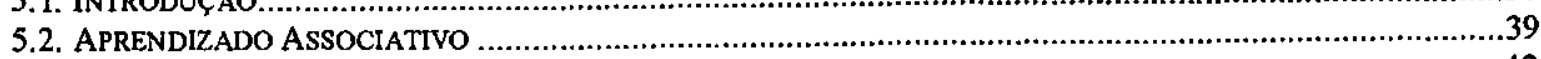

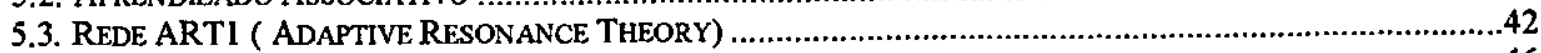

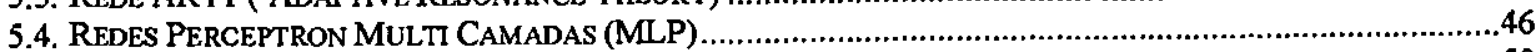

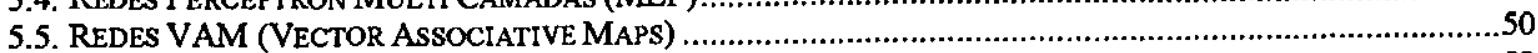

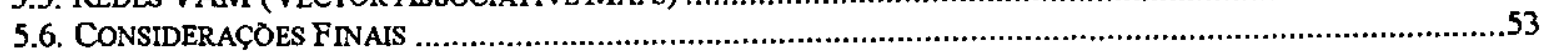

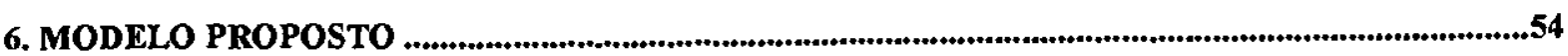

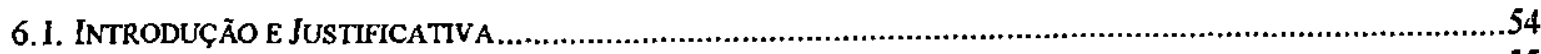

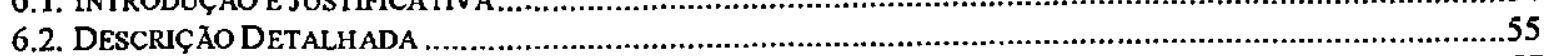

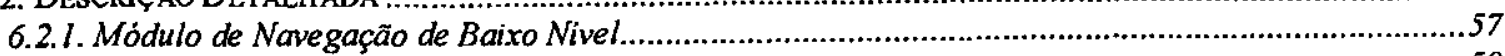

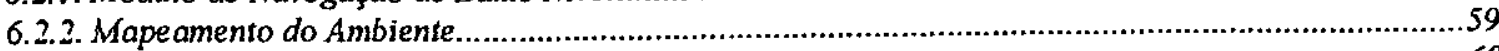

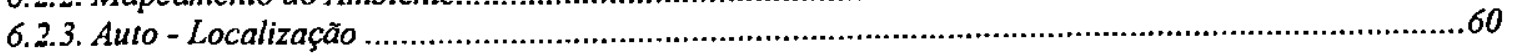




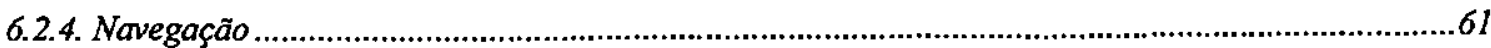

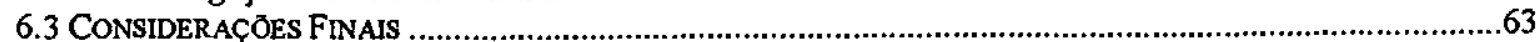

7. PROJETO DO MAPA COGNITIVO

7.1. O USO DE MAPAS PARA EXPANDIR AS CAPACIDADES DE NAVEGAÇÃO ..............................................64

7.1.1. Mapas Métricos x Mapas Topológicos.....................................................................................65

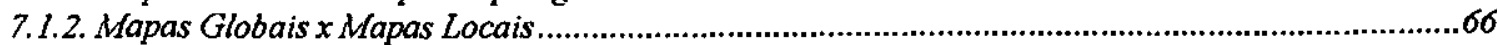

7.1.3. Mapa Local + Mapa Métrico = Mapa Cognitivo ....................................................................66

7.2. MAPEAMENTO LOCAL COM INFORMAÇÃ TOPOLÓGICA E MÉTRICA ....................................................66

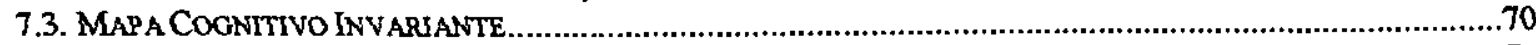

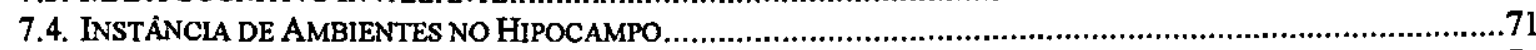

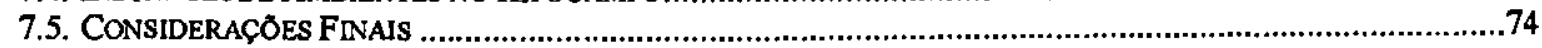

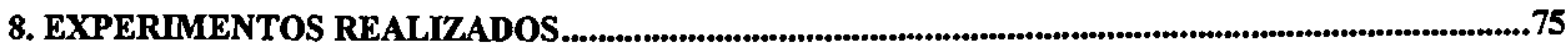

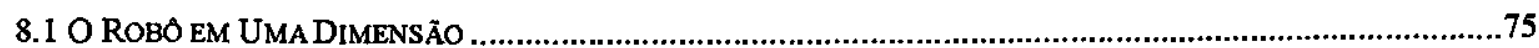

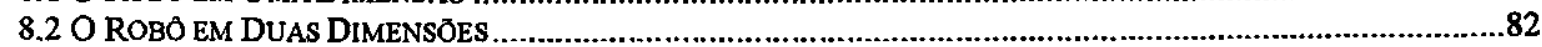

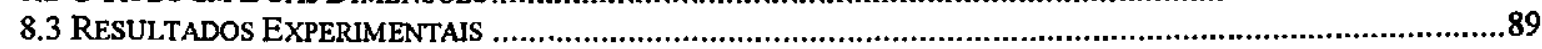

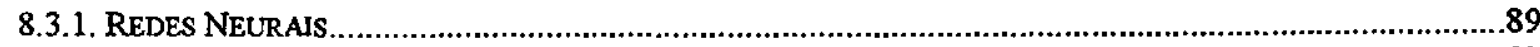

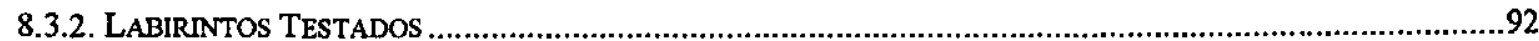

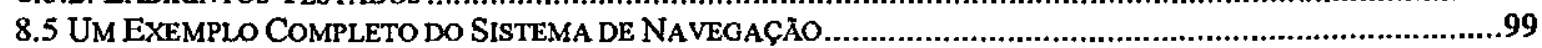

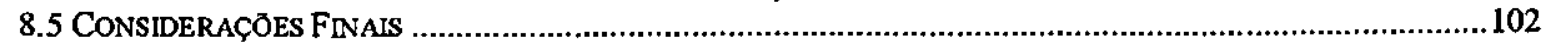

9. CONCLUSÄO .

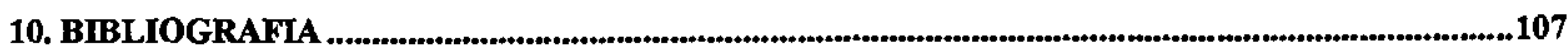

APÊNDICE A - UM MÉTODO PARA CALCULAR 0 ÂNGULO INVARIANTE...........................111

Listagem A.1: Uma implementação em C da Equação A.1 ............................................................112

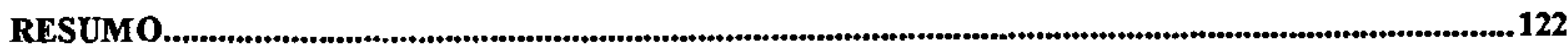

ABSTRACT 


\section{Índice de Figuras}

FIGURA 1.1 - (A) SHAKEY, O PRIMEIRO ROBÓ MÓvEL. (B) PIONEER I, UM ROBÓ MÓVEL COMERCIAL................... 1

FIGURA 1.2- ANDRÓIDES AO REDOR DO MUNDO.

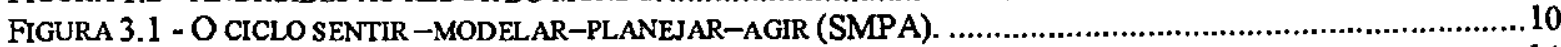

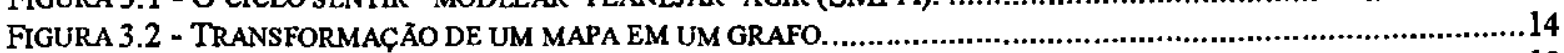

FIGURA 3.3 - DIAGRAMA DA ARQUTTETURA REATIV A DE FUSĂO DE COMPORTAMENTOS. .................................19

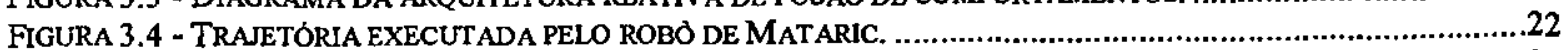

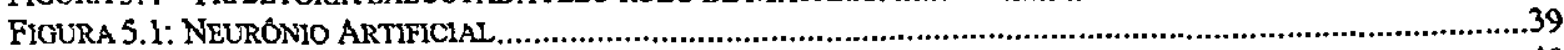

FIGURA 5.2 - OS NEURÓNIOS $V_{1} E$ V J LGaDOS ATRAVES DA SINAPSE E

FIGURA 5.3 - (A) A OUTSTAR (B) OUTST AR EM FORMA DE ESTRELA ........................................................41

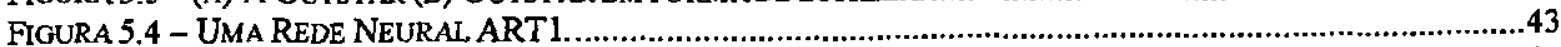

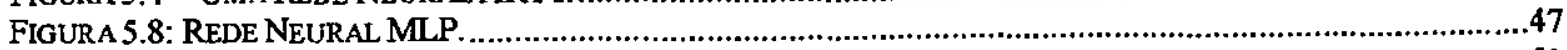

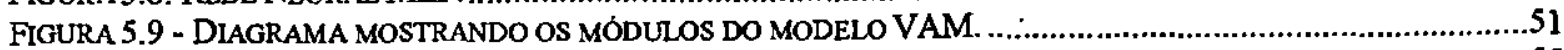

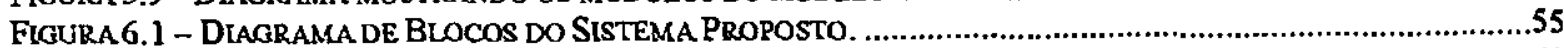

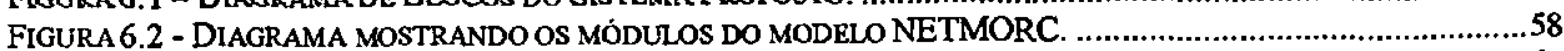

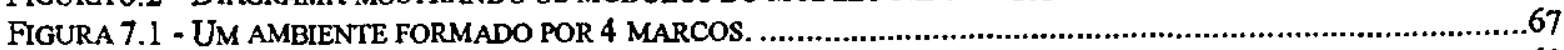

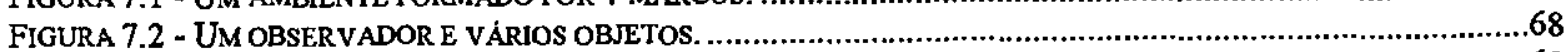

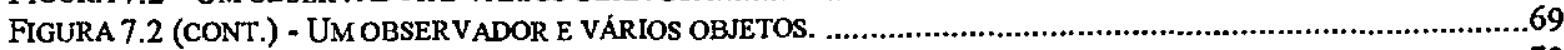

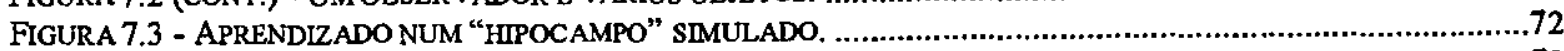

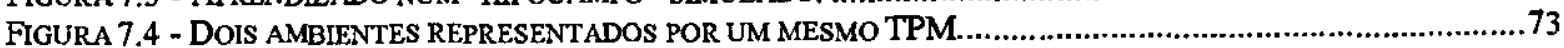

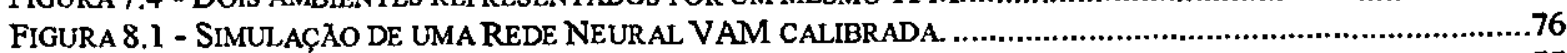

FIGURA 8.2 SIMULAÇÃo DE UMA REDE NEURAL ART 1 . ..................................................................77

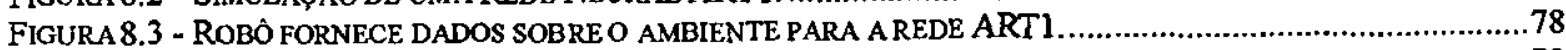

FIGURA 8.4 - ROBÒ SIMULADO FORNECENDO DADOS PARA UMA REDE VAM...............................................

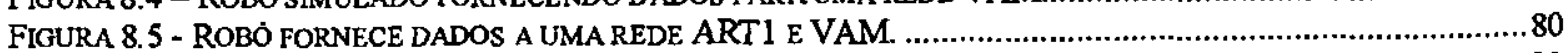

FIGURA 8.6 - REDE NEURAL VAM COMPOSTA POR DOIS MAPAS ESPACIAIS. ............................................81

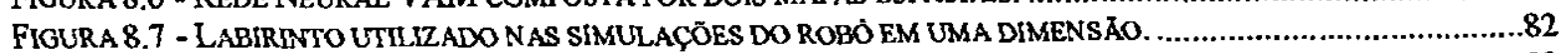

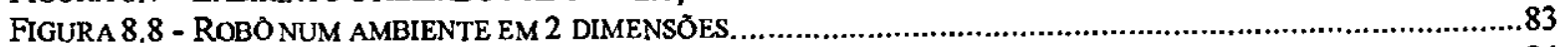

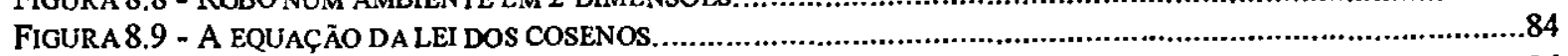

FIGURA 8.10 EQUAÇÃo PARA ENCONTRAR O ÁNGULO ENTRE O MARCO E O ALVO (ÃNGULO $\theta$ ). .......................86

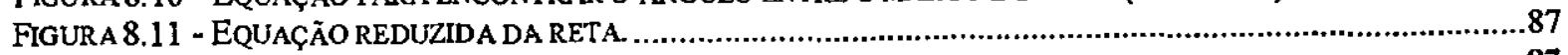

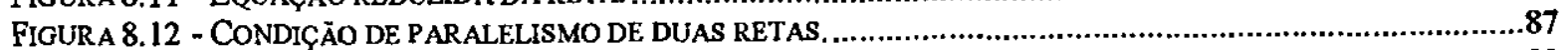

FIGURA 8.13 - LABIRINTOS UTLLLZADOS NO TESTE DO ROBÓ NA TAREFA DE NAVEGAÇÃo....................................92

FIGURA 8.13 (CONT.) - LABIRINTOS UTILIZADOS NO TESTE DO ROBÓ NA TAREFA DE NAVEGAÇĀO.....................93

FIGURA 8.13 (CONT.) - LABIRINTOS UTILIZADOS TESTE DO ROBÓ NA TAREFA DE NAVEGACÃO.........................94

FIGURA 8.14 - EXEMPLOS DO ROBO NAVEGANDO NOS LABIRINTOS 1 (A) E 3 (B)......................................95

FIGURA 8.15 - COMPARAÇÃO ENTRE OS CAMINHOS SEGUIDOS NO LABIRINTO 2 ............................................96

FIGURA 8.16 - COMPARAÇÃO ENTRE OS CAMINHOS SEGUIDOS NO LABIRINTO 4...........................................97

FIGURA 8.17 - COMPARAÇÃO ENTRE OS CAMINHOS SEGUIDOS NO LABIRINTO 5............................................97

FIGURA 8.18 - COMPARAÇÃO ENTRE OS CAMINHOS SEGUIDOS NO LABIRINTO 6 ...........................................98

FIGURA 8.19 - O LABIRINTO 7, UM SIMPLES LABIRINTO EXEMPLIFICANDO O SISTEMA DE NAVEGAÇÃO..............99

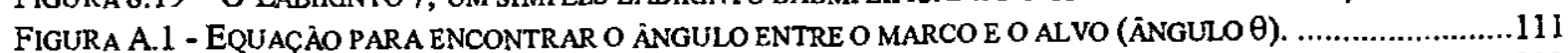

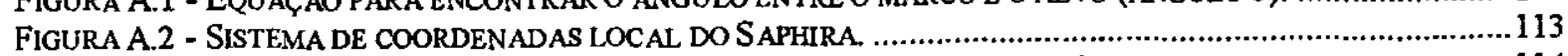

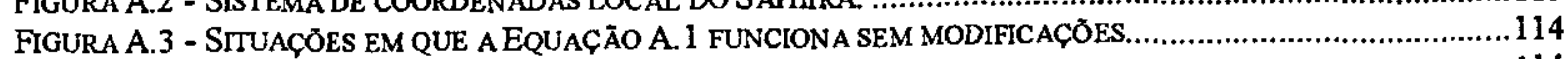

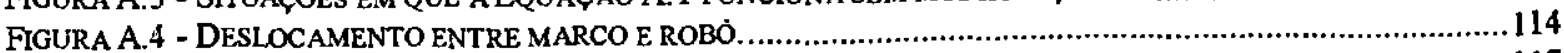

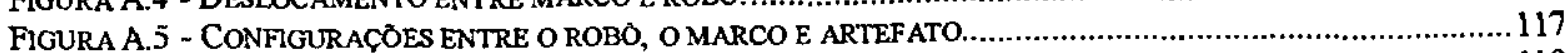

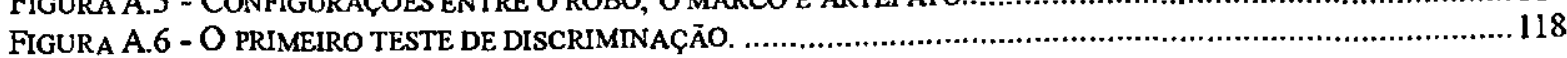




\section{Resumo}

Dentro da área da Robótica, Robôs Móveis têm recebido crescente atenção. Robôs móveis se propõem a realizar uma variedade de tarefas mais complexas que seus antecessores, os robôs industriais. Para tal, são necessárias técnicas que lhes permitam interagir de forma efetiva com o ambiente. A parte mais essencial desta interação é o Sistema de Navegação que é um conjunto de métodos e procedimentos que o robô utiliza para se locomover e encontrar seu caminho no mundo.

Infelizmente, as pesquisas até agora têm demonstrado pouco sucesso quando os robôs são submetidos a tarefas do mundo real. Métodos baseados em modelagem matemática são inadequados para os robôs móveis, porque seu ambiente é dinâmico e mutável. Já os métodos que rejeitam inteiramente os modelos do mundo e simplesmente reagem às contingências do a mbiente, não conseguem ser escalados para problemas complexos.

Apesar destas dificuldades, a natureza parece ter se saído particularmente bem ao dotar animais e seres humanos da capacidade de navegação. Uma abordagem recente é buscar inspiração nela. Esta abordagem é representada pelo estudo dos Mapas Cognitivos - estruturas mentais, encontradas em desde ratos até seres humanos, que permitem registrar fatos e raciocinar a respeito dos espaços.

Os Mapas Cognitivos da natureza são implementados em Redes Neurais Naturais - os cérebros. Pesquisadores de computação e engenharia procuram imitá-lo com as Redes Neurais Artificiais. Este trabalho propõe criar um sistema de navegação para robô móvel, inspirado no mecanismo de mapa cognitivo, implementado através de Redes Neurais Artificiais. O objetivo é obter um sistema robusto, capaz de responder as exigências de desempenho presentes em tarefas do mundo real. 


\begin{abstract}
In the area of Robotics, Mobile Robots have been receiving increasing attention, mainly because they can perform a larger variety of tasks than their predecessors, the industrial robots. Mobile Robots need techniques that enable them to interact effectively with the environment. The most essential part of this interaction is the Navigation System - the set of methods and procedures they need to walk, and find their way in the world.

Unfortunately, research has shown small success when robots are applied to real world tasks. Methods of mathematical modeling are inadequate to mobile robots, because their environment is dynamic and mutable. On the other hand, methods that completely reject world models, and just react to environment contingencies, do not scale well.

Despite these difficulties, Nature has been successful in providing animals and human beings with navigational capabilities. A recent approach is to get inspiration from Nature. This approach is represented by the study of Cognitive Maps, which are mental structures found from mice to human beings, that enables the registration of facts and the reasoning about the environment.

Nature's cognitive maps are implemented in natural neural networks - the brains. Technology tries to imitate them with Artificial Neural Networks. This dissertation proposes to build a mobile robot navigation system, inspired by the cognitive map mechanism, and implemented by Artificial Neural Networks. The aim is to obtain a robust system able to respond to the performance demand of real world tasks.
\end{abstract}




\section{Introdução}

\subsection{Contexto}

A palavra robô vem do tcheco robota, que significa trabalho (Fu et al., 1987). Ela foi usada pela primeira vez em uma peça de teatro, do escritor Karel Capek, chamada R.U.R. (Rossum's Universal Robots). Nela, a humanidade criou robôs para o trabalho, mas eles se revoltaram contra seus criadores, e os destruíram.

O marco inicial geralmente apontado como o nascimento da Robótica é a criação, por George Devol na década de 50, de um dispositivo programável para movimentar materiais (Groover et al., 1988). O dispositivo era um braço mecânico, programado através de campos magnéticos em uma fita.

A maioria dos robôs em uso no mundo hoje mudou muito pouco desde a época de Devol. O avanço mais significativo foi a inclusão de capacidades sensoriais, permitindo aos robôs uma maior precisão e flexibilidade. Mesmo assim, os robôs industriais de hoje não lembram em nada os robôs nervosos de Capek.

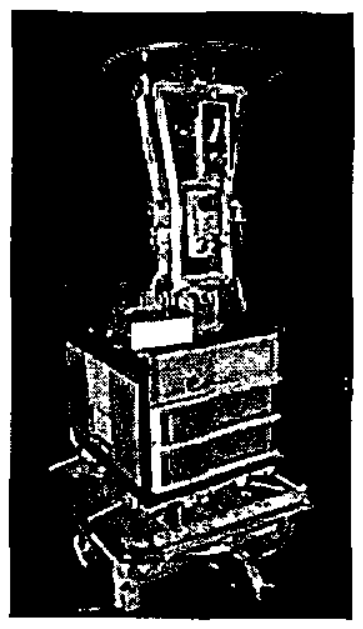

(a)

(b)

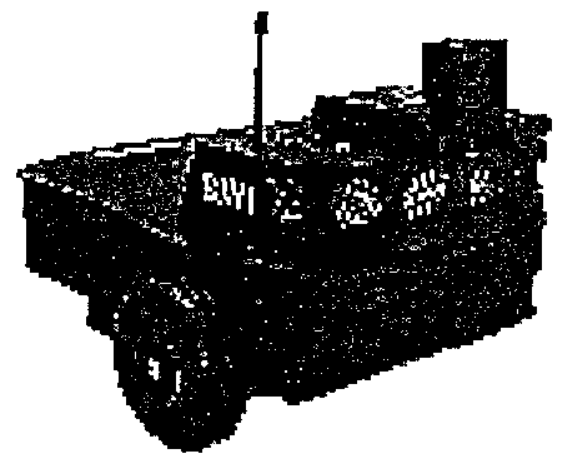

Figura 1.1 - (a) Shakey, o primeiro robô móvel. (b) Pioneer I, um robô móvel comercial.

A pesquisa de robôs móveis é uma sub área da robótica, interessada na criação de robôs que possam se locomover pelo ambiente no qual atuam. $O$ início das pesquisas em 
robôs móveis geralmente é apontado como sendo o ano de 1968, quando o SRI (Stanford Research Institute) criou o primeiro robô móvel, Shakey (Nilsson, 1969; Fikes et al., 1972), mostrado na Figura 1.1(a). Os experimentos conduzidos nesta dissertação, utilizaram o robô Pioneer I, mostrado na Figura 1.1(b).

Atualmente, importantes instituições ao redor do mundo apresentam grupos envolvidos em pesquisa de andróides. Andróides são robôs de forma humana, e sua pesquisa é cada vez mais incentivada porque percebeu-se que, em um mundo feito por humanos e para humanos, é mais racional e econômico adaptar o robô ao mundo no qual ele atuará do que o contrário.

Nos Estados Unidos, o MIT (Massachussets Institute of Technology), pesquisa o andróide Cog (Brooks \& Stein, 1993). No Japão, a Honda desenvolveu andróides chamados $P 2$ e $P 3$ (Honda, 1999). Pode-se observar dois destes andróides na Figura 1.2.

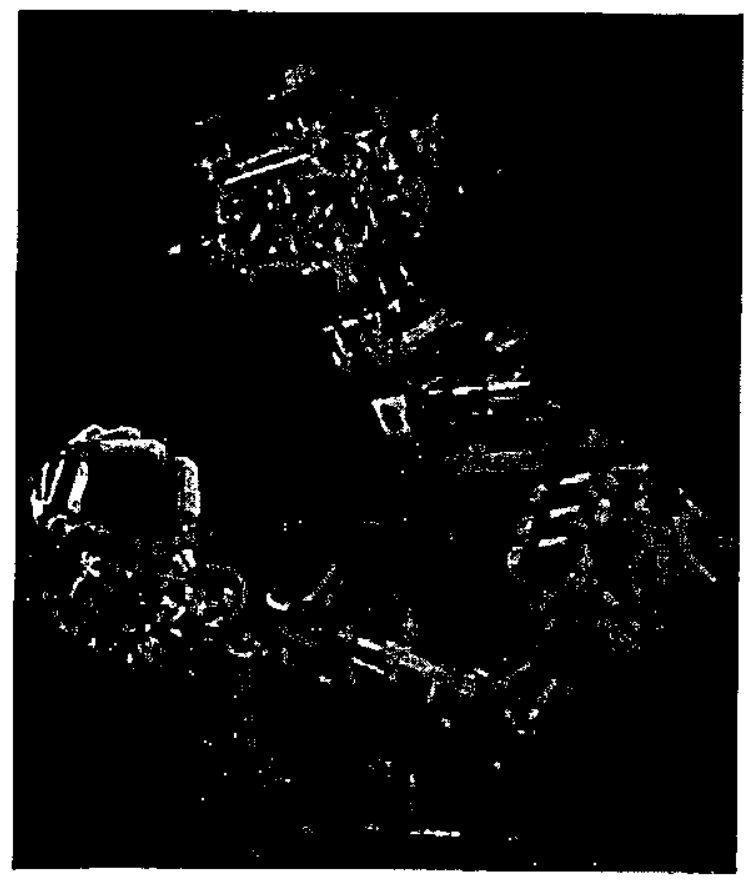

(a)

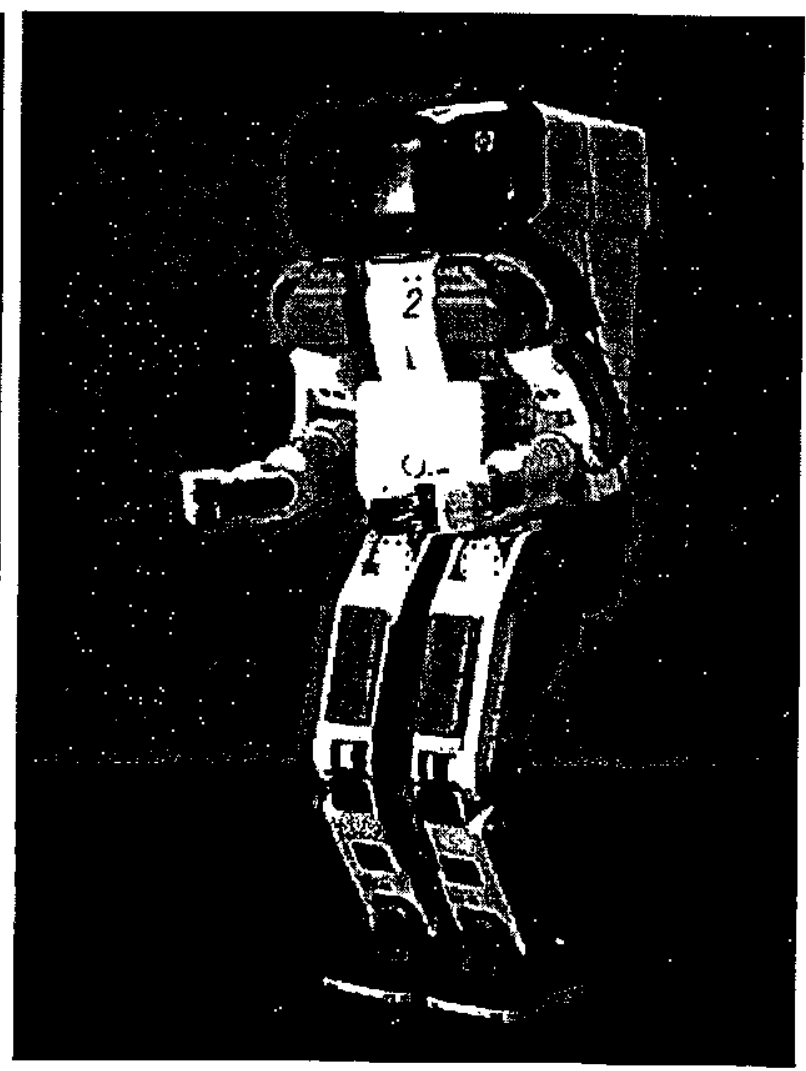

Figura 1.2- Andróides ao redor do mundo.

(a) Cog, o andróide do MTT. (b) P2, o andróide da Honda. 


\subsection{Motivação e Relevância}

A principal barreira para a criação de robôs cada vez mais avançados, não é a parte física (hardware). Com a tecnologia disponível hoje, qualquer pessoa pode criar robôs poderosos, com diversas capacidades, e relativamente baratos (Marsh, 1985; McComb, 1987; Salant, 1990; Jones \& Flynn, 1993; Iovine, 1998). Através da ligação de chips de memória e processamento em paralelo é possível atingir elevada capacidade de processamento.

A principal limitação para os robôs está em como controlá-los, ou seja, como criar programas capazes de operar estas máquinas complexas. Isto é um problema de software (Jones \& Flynn, 1993). Um dos ramos da computação que se ocupa da pesquisa destas peças de software para o controle de robôs é chamado de Inteligência Artificial (IA).

Existem vários tipos de robôs móveis, não apenas aqueles baseados em rodas. Alguns têm várias pernas, como os robôs inspirados em insetos. Outros são movidos por "músculos artificiais", utilizando polímeros especiais ou Nitinol (uma liga de níquel e titânio). Os andróides apresentam pernas semelhantes às humanas. Porém, a grande maioria é dotada de rodas. Não importa seu tipo, tamanho ou uso, todos os robôs móveis têm uma necessidade em comum: o Sistema de Navegação.

Apesar de haver um grande número de pesquisas em sistemas de navegação, ainda não existe uma solução robusta, capaz de realizar as tarefas exigidas no mundo real com eficiência e flexibilidade. A medida que a tendência para a utilização de robôs móveis aumenta, a necessidade de um sistema de navegação para eles aumenta na mesma proporção.

Uma das áreas de aplicação que vem recebendo atenção é a criação de sistemas de aspirador de pó robóticos (Ulrich et al., 1997; Burhanpurkar, 1993; Jenkins, 1993; Slack, 1993; Yamamoto, 1993). A empresa Electrolux, por exemplo, planeja lançar um produto comercial ainda em 1999. 


\subsection{Objetivos}

Este é um trabalho sobre navegação de robôs móveis. O objetivo é desenvolver um Sistema de Navegação que permita a um robô, dotado de mecanismo de movimentação, aprender a estrutura espacial do ambiente de forma autônoma e, posteriormente, partindo de um ponto arbitrário do ambiente, chegar a um ponto alvo, indicado pelo operador.

Foram estudadas na literatura diversas formas de abordar o problema da navegação em robôs móveis, avaliando os pontos fortes e fracos de cada uma delas.

Finalmente, foi decidido tomar por inspiração o mecanismo utilizado pelos seres humanos para realizar esta mesma tarefa. Este mecanismo é conhecido por Mapa Cognitivo (Schmajuk, 1996; Schmajuk \& Thieme, 1992). Para implementar este mecanismo, a ferramenta principal a ser utilizada são as Redes Neurais Artificiais.

Portanto, neste trabalho, será construído um Sistema de Navegação baseado em Mapa Cognitivo, e implementado através de Redes Neurais Artificiais.

Pode-se destacar duas possíveis contribuições do presente trabalho para o campo da Robótica: uma científica, e outra tecnológica. Sob o aspecto científico, o trabalho poderá ajudar a responder a pergunta: 'Um sistema de navegação baseado no mecanismo de mapa cognitivo é viável?'. Se a resposta for positiva, o aspecto tecnológico virá na forma de um sistema de navegação para ser usado por diversos tipos de robôs móveis, de modo a possibilitar a realização de tarefas do mundo real.

\subsection{Organização do Trabalho}

Este trabalho está dividido em três grandes partes. A primeira parte é composta dos Capítulos I e 2. Nela é apresentada uma visão geral da robótica, suas tendências atuais, a área de robôs móveis, e as aplicações desta classe de robôs.

Na segunda parte, no Capítulo 3, é apresentada uma revisão dos dois paradigmas mais utilizados para navegação, o SMPA (Sentir-Modelar-Planejar-Agir) e o Reativo. No Capítulo 4, é feita uma revisão sobre o paradigma cognitivo, o mais recente. No Capítulo 5 , são descritos os modelos de Redes Neurais que serão utilizados na implementação do sistema.

A terceira parte, composta pelos Capítulos 6, 7 e 8, apresenta o sistema de navegação proposto, sua implementação e os resultados obtidos. 


\section{A Tarefa de Navegação}

Neste Capítulo serão discutidos detalhadamente os conceitos da tarefa de navegação, e os requisitos que devem ser tratados por um sistema de navegação. Nos próximos Capítulos, as diferentes abordagens serão analisadas em relação a estes requisitos e critérios.

\subsection{Requisitos de um Sistema de Navegação}

Grande parte dos pesquisadores concorda que o objetivo de um sistema de navegação é alcançar alvos localizados no ambiente do robô, de forma rápida e sem colidir com obstáculos (Rich \& Knight, 1991; Horswill, 1993). Existe um consenso também quanto ao conceito de ser este o sistema fundamental dos robôs móveis.

Apesar de um consenso quanto aos objetivos, existem inúmeros sistemas de navegação propostos na literatura. Ainda assim, este é um problema considerado como não tendo uma solução geral definida. Isto acontece porque cada sistema faz suas próprias suposiçסes a respeito de como o ambiente está estruturado, e das informações que o robô terá a seu dispor.

Muitos sistemas assumem, por exemplo, que já existe um mapa detalhado do ambiente, fornecido pelo usuário. Outros assumem a chamada 'hipótese do mundo fechado', segundo a qual as únicas situaçðes que ocorrem no ambiente são aquelas feitas pelo próprio robô.

Neste trabalho, busca-se um sistema de navegação robusto e flexível. Em particular, é assumido que o robô atuará em um ambiente dinâmico, ou seja, admite-se que o ambiente pode se modificar sem que a ação do robô seja necessária para isso.

Outro pressuposto é que o robô deverá atuar em um ambiente formado por pessoas e possivelmente outros robôs e animais. Isto quer dizer que ele deverá evitar colisões com obstáculos móveis.

Uma questão muito importante, muitas vezes negligenciada por sistemas de navegação, é o mapeamento de espaços abertos. Espaços abertos ocorrem no meio de uma sala, por exemplo, e são lugares em que o robô pode trafegar livremente, sem obstáculos nem pontos de referência em qualquer direção. 
Muitos robôs atuam em labirintos, onde não há espaços amplos abertos, e outros simplesmente os ignoram, limitando-se a trafegar pelas bordas do ambiente, em geral seguindo as paredes. Outros ainda, se perdem quando não há pontos de referência. Um bom sistema de navegação deve ser capaz de tratar adequadamente dos espaços abertos.

Finalmente, o robô deverá ser capaz de aprender o ambiente de forma autônoma. Nenhum mapa do ambiente será fornecido a ele. Além disso, o robô não será sempre operado a partir de um ponto de partida fixo - ele poderá iniciar suas jornadas a partir de qualquer ponto no ambiente.

Com base nestas considerações, pode-se definir os requisitos para o sistema de navegação robótico de sucesso:

1. evitar colisões;

2. alcançar o objetivo rapidamente;

3. operar em um ambiente dinâmico;

4. desviar de obstáculos móveis;

5. mapear e levar em consideração os espaços abertos;

6. ser capaz de atuar em um ambiente previamente desconhecido.

\subsection{Aspectos a Serem Tratados}

Algumas situações que um sistema de navegação tem que enfrentar são casos especiais, que influenciam no desempenho do sistema de navegação. Todo sistema trata estas situações, de forma implícita ou explícita. A eficiência das soluções irá influenciar o desempenho do sistema de navegação. A partir da revisão bibliográfica, levantou-se os principais aspectos que devem receber atenção. Estes são apresentados a seguir.

\section{1) Existe divisão entre navegação de baixo e de alto nível?}

O hardware do robô só responde a voltagens aplicadas a seus atuadores, como aquelas que deverão ser aplicadas a cada um dos motores das rodas. Como as ações de alto nível, por exemplo o planejamento de rota, são transformadas em ações de baixo nível, de modo que o hardware possa executar estas ações diretamente? 
2) Como funciona a exploração de ambiente? Quando o ambiente é inicialmente desconhecido, para onde o robô vai?

Na primeira vez que o robô entra em contato com o ambiente, ele deve explorá-lo para obter conhecimento. Como é feita esta exploração? Muitos sistemas andam de forma aleatória, e outros preferem uma exploração mais sistemática. Muito do desempenho e da qualidade dos conhecimentos obtidos serão determinados pelo método de exploração.

\section{3) Como são tratados becos sem saida (dead-end's)?}

Um beco sem saída (Dead End) é um lugar onde não há como avançar. Por exemplo, o robô pode seguir por um corredor, e a porta do fim do corredor poder estar fechada. $O$ que o robô faz nesta situação? E se o objetivo do robô está logo atrás desta porta fechada, será que ele fica tentando entrar indefinidamente? Em alguns sistemas, o robô fica esperando indefinidamente pela abertura da porta. Em outros, esta situação faz com que o robô fique indo e voltando em direçâo a porta.

\section{4) Como são tratados Desvios Múltiplos?}

Quando o robô deixa um corredor, geralmente ele pode escolher entre ir para a direita ou para a esquerda. Porém, o que acontece se o robô se encontrar em um lugar no qual ele pode escolher um entre diversos caminhos possíveis? Muitos sistemas escolhem um ao acaso, outros preferem guardar aqueles caminhos que poderiam não foram seguidos, mas que poderiam ser tomados, para futura exploração.

\section{5) Como o alvo é selecionado?}

Um sistema de navegação só será útil se for possivel controlar o robô, especificando para onde se quer que ele vá. Deve haver um método, de preferência fácil e amigável ao usuário, para que ele possa especificar isto ao robô.

\section{6) Como o robô se situa (ou se acha) no ambiente?}

$O$ robô pode iniciar sua jornada em qualquer ponto do ambiente. Para poder utilizar seus conhecimentos sobre o ambiente, primeiro ele precisa saber onde ele está. O sistema de navegação deve fornecer um método para que esta localização seja possível. 


\section{7) $O$ que fazer quando o robô se perde?}

Devido a imperfeições inerentes, ou falhas momentâneas nos sensores, é possível que o robô chegue a um ponto no qual ele já não sabe onde está. Esta questão é um caso especial da anterior, e diz como um robô, que se perdeu, volta a achar o ponto no qual está localizado no ambiente.

\section{8) Como é feito o planejamento de rota? Ele garante rotas ótimas?}

Sabendo onde está, e sabendo onde deverá ir, o robô deve determinar um caminho para se mover de um lugar ao outro. Como este caminho é determinado? O robô procura pelo caminho ótimo?

\section{9) Como sāo tratadas informações ambíguas?}

Em muitos pontos do ambiente, as informações recebidas pelos sensores do robô são iguais. Isto ocorre principalmente quando o sistema de sensores tem resolução limitada, como é o caso dos sensores de ultra-som. Por exemplo, quando o robô está de frente para uma parede, ele é incapaz de dizer qual é a parede baseado apenas nas informações dos sensores. Deverá haver algum método que permita diferenciar as paredes, ou seja, eliminar a ambigüidade das informações.

\subsection{Considerações Finais}

Pode-se concluir que um sistema de navegação, por mais simples que seja, deve resolver uma série de problemas, e realizar uma série de compromissos entre possíveis soluções. Cada uma das questões terá influência no resultado final.

Foram analisados neste Capítulo os requisitos para que um sistema de navegação tenha sucesso na realização de tarefas, geralmente complexas, do mundo real. Muitos sistemas de navegação não podem ser utilizados em problemas práticos devido às suposições simplificadoras que fizeram. Nos próximos Capítulos serão analisadas diferentes soluções propostas para as várias questões discutidas neste Capítulo. 


\section{Paradigmas Para Navegação de Robô}

Neste Capítulo será visto como o problema de navegação para robôs móveis tem sido abordado na literatura. Basicamente, existem 3 linhas de pesquisa que propõe soluções para o problema. A primeira é conhecida como Paradigma Sentir-Modelar-Planejar-Agir, ou SMPA (Medeiros, 1998). Em vários casos, os sistemas que seguem este paradigma são baseados em modelos matemáticos, e são fortemente dependentes da acuidade de sensores e atuadores. A segunda, conhecida como Paradigma Reativo, sustenta que os sistemas de controle devem ser reativos, ao invés de dependentes de planos (Medeiros, 1998). A terceira e mais recente pode ser chamada de Paradigma Cognitivo, e sugere que pode-se aplicar alguns princípios utilizados por animais e seres humanos para a navegação, uma vez que estes sistemas biológicos são exemplos de sistemas de navegação de sucesso, pois permitem a humanos e animais se locomoverem com segurança pelo mundo (Kortenkamp, 1993)

Neste Capítulo, as duas primeiras linhas de pesquisa serão analisadas. O próximo Capítulo será dedicado especialmente à terceira, por ser aquela sobre a qual está baseado este trabalho.

\subsection{Paradigna SMPA}

O paradigma SMPA se caracteriza por construir e atualizar um modelo do mundo utilizado pelo robô para realizar suas tarefas. O processamento é realizado em ciclos, chamados de ciclos sentir-modelar-planejar-agir. Em cada ciclo, o robô obtém dados do ambiente através de seus sensores, realiza um processamento nestes dados brutos, transformando-os em informação útil e utiliza esta informação para atualizar seu modelo do mundo. De posse de um modelo atualizado, é feito um planejamento das próximas ações, e a próxima ação imediata é enviada aos atuadores (Thurn \& Bücken, 1996). A Figura 3.1 apresentada o paradigma SMPA. Nesta Seção, será analisado o trabalho realizado por Thurn \& Bücken (1996), como exemplo do paradigma SMPA. 


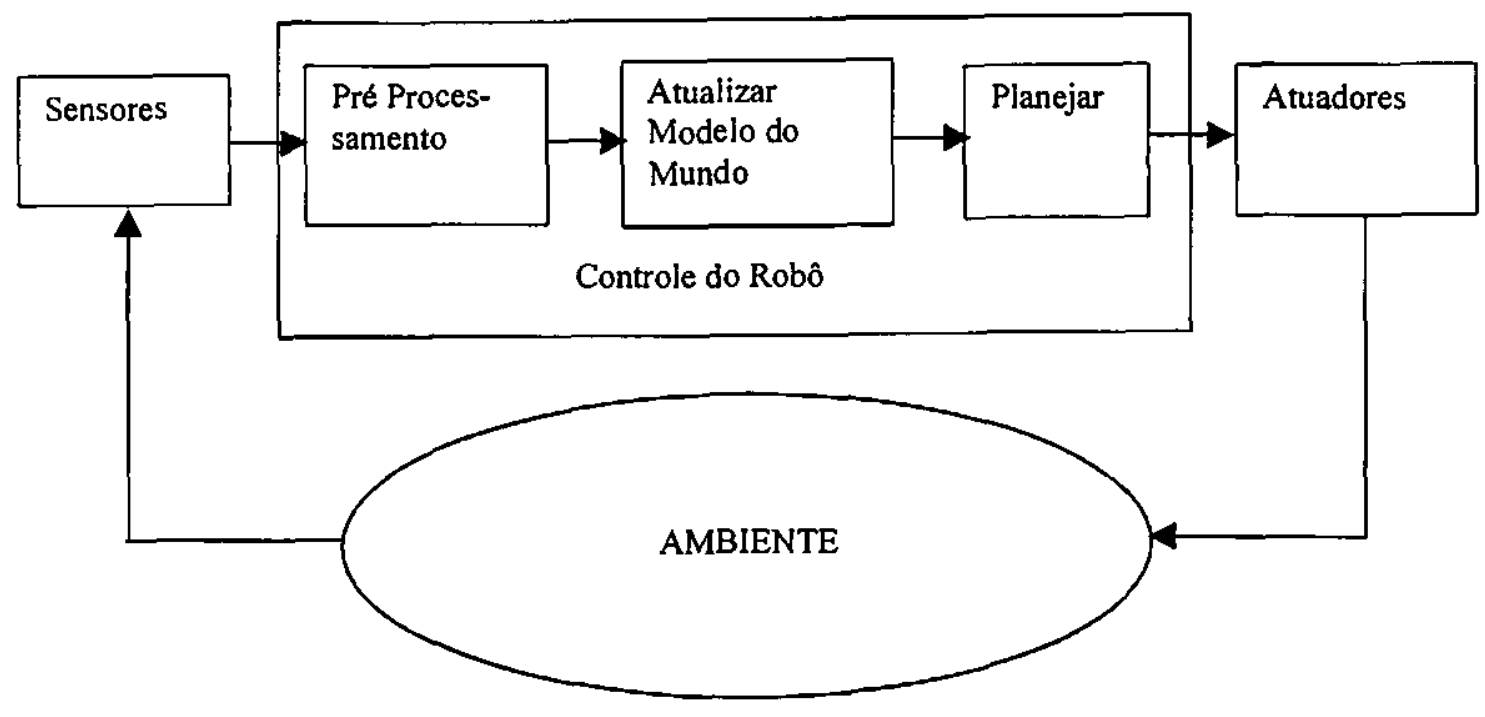

Figura 3.1 - O ciclo sentir-modelar-planejar-agir (SMPA).

O modelo do mundo mais utilizado nos robôs móveis é o mapa. Um mapa é uma estrutura de dados representando parte do mundo. A utilização de mapas em tarefas de navegação tem várias vantagens: mapas são bem entendidos, facilitam a especificação de novas tarefas de navegação e também são capazes de sintetizar e compactar os dados recebidos pelos sensores. Mapeamento, segundo Thurn (Thurn et al., 1997), é o processo de construir um modelo do ambiente (o mapa), baseado em leituras sensoriais. Por exemplo, na Figura 3.1, o mapa do ambiente poderia corresponder ao modelo do mundo.

Em geral, o ambiente é percebido através de sensores de visão, ou ultra-som. A medida que o robô vai andando de um ponto a outro no ambiente, sensores nas rodas informam quanto foi andado. Esta informação é utilizada para determinar a que distância os objetos estão uns dos outros e do robô. O sensor que fornece esta informação é uma espécie de odômetro, chamado wheel encoder. Um mapa obtido desta forma é chamado de mapa baseado em geometria, ou mapa métrico.

Quando tem-se o mapa métrico pronto, é possivel transformá-lo em um grafo, que é chamado de mapa topológico. O mapa topológico é útil porque permite que sejam utilizados algoritmos de busca em grafos, que podem inclusive planejar rotas ótimas.

A seguir serão descritas as operações que são efetuadas para se mapear o ambiente e transformá-lo em um grafo. Considerando que o robô possui sensores ultra-sônicos.

O mapa métrico lembra, conceitualmente, um grande tabuleiro de xadrez. Para entender melhor, pode-se imaginar um chão pintado com um quadriculado, com várias linhas 
verticais e horizontais. Cada ponto do ambiente está contido em uma determinada célula deste quadriculado.

Cada célula tem um valor associado a ela, chamado de valor de ocupância, que denota a probabilidade de que aquela célula esteja ocupada. Para a célula $(x, y)$, o valor de ocupância é denotado por Prob(occ $x, y)$.

\subsubsection{Mapeamento do Ambiente}

Para aprender um ambiente novo, o robô deve ser colocado na origem do sistema de coordenadas global. A origem do sistema de coordenadas pode ser escolhido arbitrariamente. Em outras palavras, o lugar onde o robô se encontra, seja ele qual for, é inicialmente escolhido para se tornar a origem do sistema de coordenadas.

De qualquer forma, a localização inicial do robô é, por definição, conhecida. A dificuldade maior durante a navegação é detectar quando ocorrem escorregões (slip), derrapagens (skid) e deslocamentos passivos (drift), e compensar estes tipos de erro, chamados de erros de curto prazo. Mais informações a respeito da exploração do ambiente é encontrado na Seção 3.1.3.

Quanto à navegação, os sensores retornam a distância para os obstáculos mais próximos, junto com ruídos. As leituras retornadas pelos sensores devem ser transformadas para valores de probabilidade de ocupância $\operatorname{Prob}\left(\mathrm{occ}_{\mathrm{x}, \mathrm{y}}\right)$ dos blocos próximos ao robô.

Uma solução possível para o problema dos ruídos é treinar uma Rede Neural, tal que, dada uma leitura do sonar, ela forneça a probabilidade de ocupância de cada célula do mapa. A rede gera como saída um conjunto de valores entre 0 e 1 , que são associados às células. $O$ valor associado a cada célula é interpretado diretamente como a probabilidade de ocupação daquela célula.

Se os sensores fossem confiáveis, um mapa de bits bastaria, onde as posições seriam marcadas como ocupadas ou desocupadas, eliminando-se as probabilidades. Como será necessário tratar ruídos, aconselha-se utilizar operações estatísticas, e integrar as leituras sensoriais através do tempo para obter um mapa consistente e preciso.

A probabilidade de ocupância de uma célula com coordenadas $\mathrm{x}$ e $\mathrm{y}\left(\mathrm{occ}_{\mathrm{x}, \mathrm{y}}\right)$ depende da leitura $t$ do sensor (denotada por $s^{(t)}$ ). Assim, tem-se que a probabilidade da célula (x,y) estar ocupada, dada a leitura sensorial $s^{(t)}$, é representada da seguinte forma: Prob $\left(\mathrm{occ}_{\mathrm{x}, \mathrm{y}} \mid \mathrm{s}^{(t)}\right)$ 
O mapa é obtido integrando-se estas probabilidades para todas as leituras sensoriais através do tempo, denotadas por $s^{(1)}, s^{(2)}, \ldots, s^{(T)}$. Ou seja, o valor de ocupância para cada célula pode ser escrito como a probabilidade $\operatorname{Prob}\left(\mathrm{occ}_{x, y} \mid \mathrm{s}^{(1)}, \mathrm{s}^{(2)}, \ldots, \mathrm{s}^{(\mathrm{T})}\right)$, que é condicionada a todas as leituras sensoriais.

Uma maneira fácil de estimar esta quantidade é aplicar a regra de Bayes (Rich \& Knight, 1991). Para fazer isso, é necessário assumir a independência do ruído nas diferentes leituras. Mas especificamente, dada a ocupância real da célula $(x, y)$, pressupõe-se que a probabilidade condicional Prob(s $\left(\mathrm{s}^{(\mathrm{t})} \mid \mathrm{occ}_{\mathrm{x}, \mathrm{y}}\right)$ é independente da probabilidade $\operatorname{Prob}\left(\mathrm{s}^{\left(\mathrm{t}^{\prime}\right)} \mid \mathrm{occ}_{\mathrm{x}, \mathrm{y}}\right)$, para $\mathrm{t} \neq \mathrm{t}^{\prime}$. Este pressuposto, um pressuposto markoviano (Thurn et al., 1997), é feito normalmente em abordagens para criar mapas de ocupância. A probabilidade desejada pode ser computada pela seguinte equação:

$$
\begin{aligned}
& \operatorname{Prob}\left(o c_{x, y} \mid \mathrm{s}^{(1)}, \mathrm{s}^{(2)}, \ldots, \mathrm{s}^{(\mathrm{T})}\right)= \\
& 1-\left(\mathrm{I}+\frac{\operatorname{prob}\left(o c c_{x, y}\right)}{1-\operatorname{prob}\left(o c x_{x, y}\right)} \prod_{t=1}^{T} \frac{\operatorname{prob}\left(o c x_{x, y} \mid \mathrm{s}(\tau)\right)}{1-\operatorname{prob}\left(o c c_{x}, y \mid s(\tau)\right)} \frac{1-\operatorname{prob}\left(o c c_{x, y}\right)}{\operatorname{prob}\left(o c c_{x, y}\right)}\right)^{-1}
\end{aligned}
$$

Na qual:

Prob $\left(\mathrm{occ}_{\mathrm{x}, \mathrm{y}}\right)$ é a probabilidade prévia da ocupação, definida inicialmente como 0,5.

Esta fórmula foi derivada em Moravec (Moravec, 1988), e pode ser utilizada para atualizar incrementalmente os valores das probabilidades de ocupância.

\subsubsection{Transformação do Mapa Métrico em Mapa Topológico}

O próximo passo é criar um mapa topológico a partir do mapa métrico obtido. A idéia básica é particionar os espaços livres em um pequeno número de regiões, separadas por linhas, chamadas linhas críticas. Estas linhas críticas correspondem a passagens estreitas, como portas. $\mathrm{O}$ mapa particionado é então mapeado para um grafo. $\mathrm{O}$ algoritmo é o seguinte:

1. Limiar: Escolhe-se um limite para o valor da ocupância. Acima deste limite, a célula é considerada ocupada $(\overline{\mathrm{C}})$, e abaixo, desocupada $(\mathrm{C})$.

2. Diagrama de Voronoi: Considere um ponto arbitrário $(x, y) \in C$ no espaço livre. Os pontos base de $(x, y)$ são os pontos mais próximos $\left(x^{\prime}, y^{\prime}\right)$ no espaço ocūpado (C), ou seja, 
todos os pontos $\left(x^{\prime}, y^{\prime}\right) \in C$ que minimizam a distância euclidiana para $x, y$. Estes pontos $\left(x^{\prime}, y^{\prime}\right)$ são chamados de pontos bases de $(x, y)$, e a distância entre $(x, y)$ e seus pontos base é chamada de desobstrução (folga) de $(\mathrm{x}, \mathrm{y})$. $\mathrm{O}$ diagrama de Voronoi, que é uma forma de esqueletização, é o conjunto de pontos no espaço livre que tem pelo menos dois pontos base diferentes e eqüidistantes (Thurn et al., 1997). (Ver Figura 3.2a).

3. Pontos Críticos: A idéia chave do particionamento do espaço livre é achar os pontos críticos. Os pontos críticos $(\mathrm{x}, \mathrm{y})$ são pontos no diagrama de Voronoi que minimizam localmente a desobstrução. Ou seja, cada ponto crítico $(x, y)$ tem duas propriedades: 1) é parte do diagrama de Voronoi, e 2) existe um $\varepsilon>0$ para o qual a folga de todos os pontos em uma vizinhança - $\varepsilon$ de $(x, y)$ é não menor. (Ver Figura 3.2b).

4. Linhas Críticas: As linhas críticas são obtidas conectando cada ponto crítico com seus pontos base. Os pontos críticos têm exatamente dois pontos base (porque senão, eles não seriam o mínimo local da função de desobstrução). As linhas críticas particionam o espaço livre em regiões disjuntas. (Ver Figura 3.2c).

5. Grafo Topológico: O particionamento é mapeado em um grafo. Cada região corresponde a um nó do grafo topológico, e cada linha crítica corresponde a um arco. (Ver Figura 3.2d). 
(a) Diagrama de Voronoi

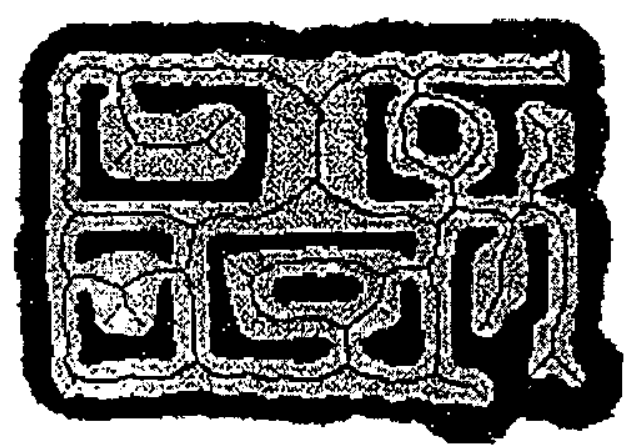

(c) Regiōes

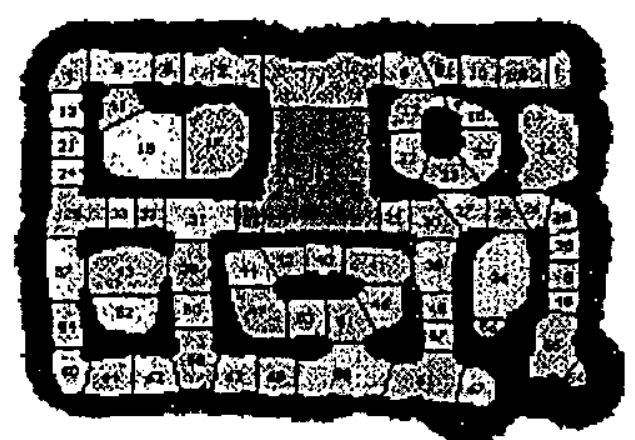

(b) Linhas Criticas (e Pontos Criticos)

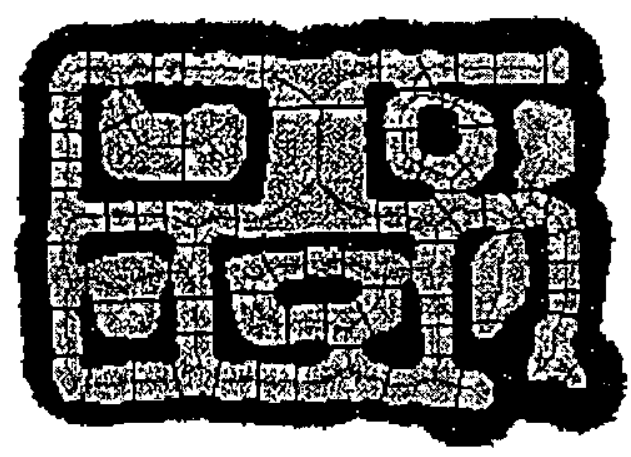

(d) Grafo Topológico

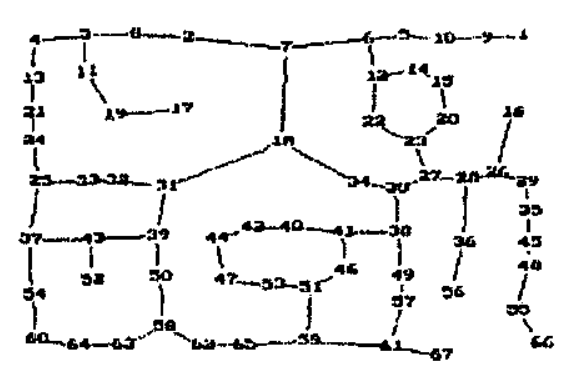

Figura 3.2 - Transformação de um mapa em um grafo.

\subsubsection{Auto Localização}

A acuidade do mapa métrico é fortemente influenciada pelo alinhamento do robô com seu mapa, ou seja, o robô deve saber onde ele está localizado dentro de seu mapa. Este processo pode ser visto como o alinhamento do sistema de coordenada local do robô com o sistema de coordenadas global do mapa.

Se o sistema de navegação se basear apenas nas informações recebidas pelos sensores das rodas, em pouco tempo estará perdido. A margem de erro deste tipo de sensor, no robô Pioneer I, por exemplo, é de aproximadamente $1 \%$, e estes erros se acumulam a cada movimento. Isto quer dizer que depois de 100 movimentos, ele não terá mais a mínima segurança para saber onde está.

Se o robô está em um ponto qualquer do ambiente, e este ponto é desconhecido, é necessário determinar o local $1(t)$, em que ele se encontra. Como não há certeza sobre sua 
localização, o problema pode ser abordado utilizando-se um modelo probabilístico. Este modelo estimará a probabilidade, ou o grau de certeza a respeito da posição atual do robô.

Considere que o robô está localizado em um ponto $\mathrm{I}^{(t)}$, inicialmente desconhecido. Cada ponto do ambiente faz parte da densidade de probabilidade $\operatorname{Prob}^{(t)}(1)$, sobre todas as localizações 1. É necessário estimar a $\operatorname{Prob}^{(t)}(1)$, de modo que ela seja o mais próxima possivel a verdadeira localização, $\mathbf{l}^{(t)}$.

Inicialmente, no tempo $t=0$, $\operatorname{Prob}^{(0)}(1)$ pode ser distribuída uniformemente, assumindo que o robô não saiba sua posição, ou, alternativamente, $\operatorname{Prob}^{(0)}(1)$ pode conter um único pico em $1^{(0)}$ se 0 robô souber sua localização.

A Prob(l) é atualizada a cada ciclo de sentir-modelar-planejar-agir do robô, usando métodos geralmente ad hoc para determinar a probabilidade condicional Prob( $\left(\mathrm{s}^{(\mathrm{t})} \mid 1\right)$ :

$$
\operatorname{Prob}^{(t)}(1) \leftarrow \alpha \int \operatorname{Prob}^{(t-1)}(1) * \operatorname{Prob}\left(s^{(t)} \mid 1\right) d 1
$$

Na qual:

$\alpha$ é um normalizador

$s^{(t)}$ é a entrada sensorial no momento $t$

Prob $\left(s^{(t)} \mid l\right)$ é a probabilidade de observar $s(t)$ quando em 1 .

Quanto aos sensores usados, geralmente melhores resultados são obtidos usando vários sensores simultaneamente. Mas para realizar a fusão dos dados das diferentes modalidades sensoriais, o custo computacional aumenta.

Para saber onde o robô está a qualquer tempo, calcula-se a probabilidade de localização para todos os pontos do ambiente, e assume-se que o robô está naquele ponto com a maior probabilidade.

Finalmente, conforme afirmado na Seção 3.1.1., são apresentadas a seguir maiores informaç̃es sobre o sistema de exploração do ambiente. Conforme foi visto naquela Seção, o robô inicia o mapeamento sabendo onde está. Por isso, enquanto ele está explorando o ambiente, ele não precisa calcular as probabilidades de todo o labirinto para saber onde está. Basta que ele estime somente o ponto l, que maximize a Prob(1). Este ponto 1 está localizado exatamente em seus arredores. 
Outra observação importante é a seguinte: não há como recuperar a posição real no caso do robô se perder quando está mapeando. Isto porque não há pontos prévios de referência pelos quais se orientar. A solução é começar o mapeamento novamente.

\subsubsection{Navegação}

No caso específico do robô RHINO (Thurn et al., 1997), existem dois módulos para realizar a navegação: um de baixo nível, e um de alto nível. O módulo de baixo nível é responsável pela execução das ordens do módulo de alto nível, e pela tarefa de evitar colisões. O módulo de alto nível (planejador global) é responsável pelo planejamento de rotas ótimas para o robô.

Como o robô dispõe de um mapa métrico, bem como de um mapa topológico, o módulo de planejamento pode atuar em qualquer um deles.

No planejamento com mapa métrico, o robô RHINO utiliza-se o algoritmo de programação dinâmica conhecido como iteração de valor, um pouco modificado. Ele gera rotas ótimas (ou seja, de menor caminho). A seguir são apresentados os passos do algoritmo.

1. A célula que contém a localização alvo é inicializada com 0 , e todas as outras com $\infty$.

$V_{x, y}= \begin{cases}0, & \text { se }(x, y) \text { é a célula alvo } \\ \infty, & \text { caso contrário }\end{cases}$

2. Para todas as células não alvo $(x, y)$, faça:

$$
\begin{gathered}
V_{x, y} \leftarrow \min \left\{V_{x+\xi, y+\zeta}+\operatorname{Prob}\left(\text { occ }_{x+\xi, y+\zeta}\right)\right\} \\
\xi=-1,0,1 \\
\zeta=-1,0,1
\end{gathered}
$$

A iteração de valor atualiza o valor de todas as células do mapa pelo valor de seus melhores vizinhos, mais o custo de mover para seu vizinho, exatamente como o algoritmo A* (Rich \& Knight, 1991). O custo é equivalente à probabilidade $\operatorname{Prob}\left(\mathrm{occ}_{\mathrm{x}, \mathrm{y}}\right)$ de que a célula $(\mathrm{x}, \mathrm{y})$ está ocupada. A regra de atualização é iterativa. Quando a atualização converge, cada 
valor $V_{x, y}$ mede o custo acumulado para se mover para o alvo mais próximo. Porém, o controle pode ser gerado a qualquer momento, bem antes da iteração de valores convergir.

3. Determinar a direção do movimento: Para determinar para onde se mover, o robô gera um caminho de custo mínimo ao alvo. Isto é feito pela descida mais íngreme em $\mathrm{V}$, iniciando na posição atual do robô. $O$ caminho de descida íngreme é então pós processado para manter uma folga mínima em relação aos muros, e se possível, se mover paralelamente aos muros, usando a orientação global dos mesmos.

O procedimento pode ser melhorado, mas mesmo assim, ele ainda é muito ineficiente para problemas do mundo real. Para um labirinto de $30 \mathrm{~m} \times 30 \mathrm{~m}$, o algoritmo demora 10 segundos para convergir, utilizando uma máquina SUN Sparcstation (Obs.: não foram fornecidos detalhes sobre o modelo do computador, nem se estava dedicado inteiramente a tarefa). Por isso, freqüentemente, o planejamento usando o mapa topológico é preferido. Para efetuar um planejamento com o mapa topológico, são seguidos três passos:

1. Planejamento Topológico: realiza-se uma busca no grafo, da posição atual do robô, até a posição final. Um algoritmo de busca de grafo é utilizado, como o algoritmo $\mathrm{A}^{*}$.

2. Planejamento Tríplice: o plano topológico deve ser transformado para comandos de movimento. Isto é feito por um "planejador tríplice". Este planejador gera caminhos métricos para cada conjunto de três regiões topológicas adjacentes no plano topológico.

3. Planejamento Final de.Alvo: o Planejador Tríplice leva o robô até a região do alvo. Uma vez nesta região final, o robô tem que realizar um planejamento mais fino, para andar até o alvo. Esta é a tarefa desta parte do algoritmo.

O método de planejamento topológico, ainda que ótimo em termos de pontos no grafo, perde de $1 \%$ a $4 \%$ em termos de eficiência para os planos gerados a partir do mapa métrico. Esta perda é considerada aceitável, por causa da grande economia em custo computacional para a obtenção da rota. 


\subsubsection{Avaliação Geral}

Estes métodos específicos, baseados no paradigma SMPA, apresentam uma série de dificuldades, muitas das quais são comuns a outros sistemas baseados no mesmo paradigma. Algumas destas dificuldades são apresentadas a seguir:

- Não conseguem tratar de ambientes dinâmicos: mapas tornam difícil modelar obstáculos móveis. A modelagem de obstáculos semi - móveis, como portas que podem estar abertas ou fechadas, é um pouco mais fácil. Modelar obstáculos móveis como seres humanos, é um problema aberto em navegação baseada em mapas.

- Sintonia de Sensores: Sistemas baseados em mapas métricos dependem de sensores que se não são perfeitos, pelo menos devem ser estáveis, ou seja, não sofrer deterioração na performance a medida que o tempo passa. Isto é um requerimento pesado, para qualquer peça mecânica. A opção é utilizar modelos dos sensores que são ajustados enquanto o robô está operando, o que leva a novas dificuldades.

- A integração de sensores adicionais não é uma tarefa fácil, porque cada sensor tem uma forma própria, única, de perceber o ambiente.

- Escalabilidade: Existem limites intrínsecos de quão bem um robô pode se localizar incrementalmente (apenas detectando e corrigindo os erros de curto prazo, como derrapagem), sem a utilização de um sistema de posicionamento global. 


\subsection{Paradigma Reativo}

Este paradigma foi introduzido por Rodney Brooks (Brooks, 1986), com sua subsumption architecture. Esta arquitetura é mais conhecida atualmente como arquitetura baseada em comportamentos. $\mathrm{O}$ paradigma reativo é caracterizado por rejeitar, ou minimizar as informações de estado internos, bem como as informações sobre um modelo do mundo.

Em sua forma original, no sistema de Brooks os comportamentos podiam suprimir uns aos outros, sem respeitar hierarquias, o que pode levar a um comportamento errático.

Um avanço sobre os comportamentos independentes e potencialmente conflitantes é a arquitetura de fusão de comportamentos reativos, cujo diagrama é mostrado na Figura 3.3. Nesta arquitetura, existe um módulo de fusão e um módulo supervisor, que são responsáveis por avaliar os sensores e decidir, entre os comportamentos aplicáveis em dado momento, qual terá o controle do robô. Sua vantagem é que apenas um comportamento, em geral pequeno, é ativado por vez e nenhum modelo do mundo é criado e mantido, reduzindo assim o tempo de processamento.

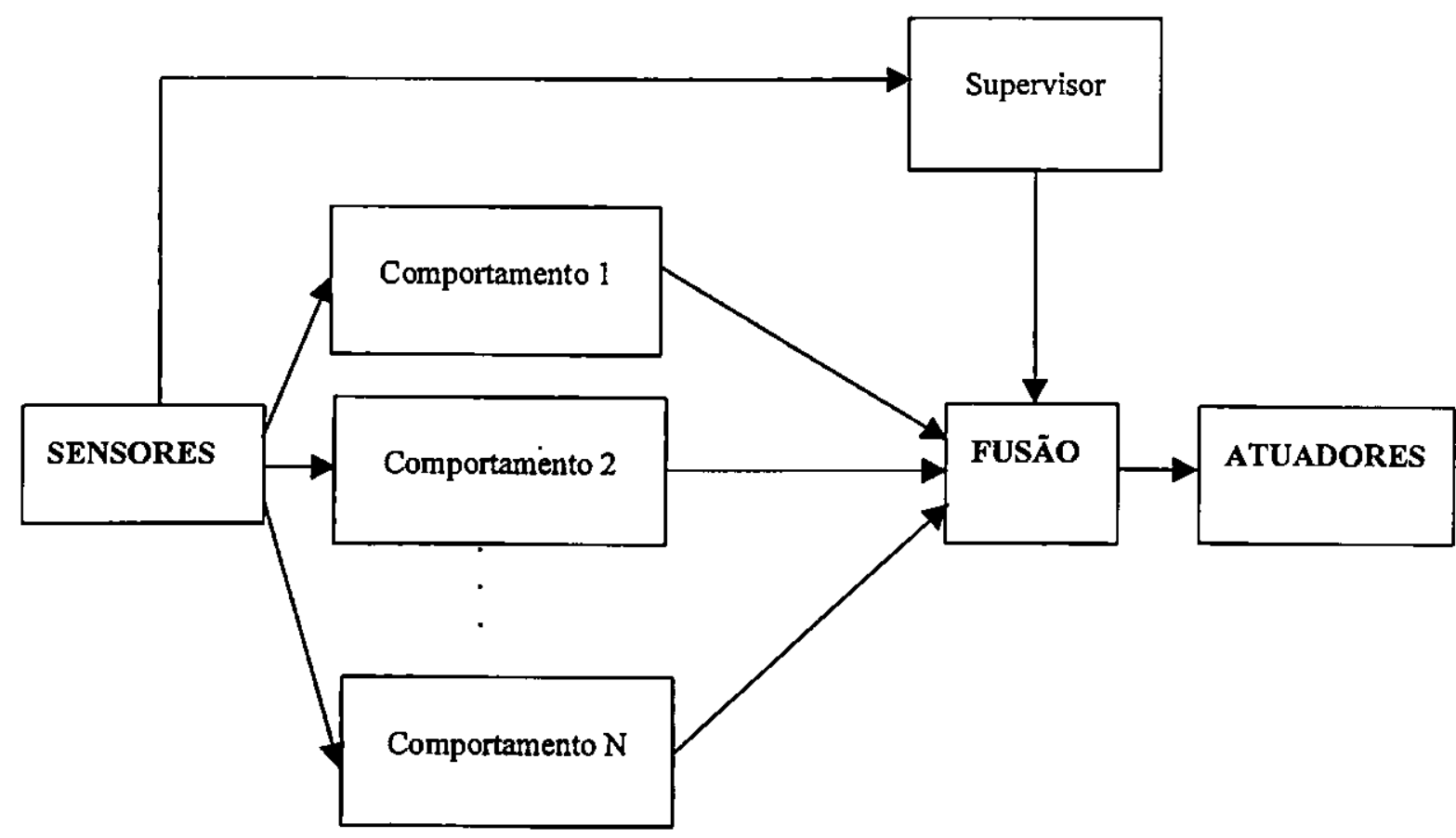

Figura 3.3 - Diagrama da arquitetura reativa de fusão de comportamentos.

Em 1990, Mataric criou um robô chamado Toto, que tinha a missão de navegar por um ambiente inicialmente desconhecido, utilizando para isso, um sistema baseado em 
comportamentos (Mataric, 1990). O objetivo era investigar como o método se comportaria nesta tarefa específica em um robô real.

Outro trabalho mais recente, que segue as idéias reativas, é apresentado por Tani (Tani 1997, 1996). Mas seus objetivos são menos ambiciosos do que aqueles de Mataric.

Nesta Seção será oferecida uma revisão do trabalho de Mataric, como exemplo de um sistema baseado no paradigma reativo, por ser o mais próximo do problema tratado nesta monografia.

\subsubsection{Mapeamento do Ambiente}

No trabalho desenvolvido por Mataric (1990), o robô só se movimenta em dois sentidos, esquerda ou direita. Os locais são representados como nós em um grafo. Em geral, cada nó tem dois vizinhos, o da esquerda, e o da direita. Mas quando um local apresenta a possibilidade de desvios múltiplos, o nó do grafo terá vários arcos saindo dele, podendo criar um grafo cíclico, não direcionado. Por isso, há também um mecanismo para detectar ciclos. Não há um mecanismo explícito para registrar o desvio e a navegação é feita pelas regras contidas nos comportamentos de baixo nível. Porém, através da leitura de um compasso (um tipo de sensor que utiliza coordenadas globais), o sistema consegue determinar os lugares pelos quais já passou. Não há garantias de que o ambiente seja completamente explorado.

\subsubsection{Auto Localizaçăo}

Para se localizar no ambiente, o robô lê seus sensores e esta informação é espalhada para todos os nós do grafo. Cada nó compara a informação recebida com sua própria descrição e sinaliza se são semelhantes. Quando um nó do grafo fica ativo, ele envia uma mensagem de expectativa para seus vizinhos da esquerda ou da direita, conforme o sentido da viagem (esquerda ou direita), alertando o nó para esperar uma possível ativação. Sempre que um marco é casado com um nó e aquele nó estava com expectativa, o casamento é considerado válido e o robô está confiante de onde ele está localizado no ambiente.

O sistema também utiliza a informação de um compasso para determinar se dois marcos são o mesmo ou diferentes. Se um marco é encontrado que casa com um nó do grafo, mas não era esperado, sua posição estimada é comparada com a estimativa da posição atual do robô. Se as estimativas casam, dentro de um limite de erro, assume-se que o caminho fez um ciclo. 
Quando o robô se perde, os mesmos mecanismos usados para determinar a posição entram em cena. $O$ robô anda pelo ambiente, reconhecendo um marco. Esta informação é espalhada para todos os nós do grafo, e aquele cuja descrição interna casa com a informação recebida responde. $O$ nó que responder envia mensagens de expectativa para os nós adjacentes. Se estas expectativas forem cumpridas, o robô estará certo de que o nó acionado é o local onde está.

\subsubsection{Navegação}

Mataric usou um método de navegação intuitivo, isto é, não modelado matematicamente, como ocorre com outros métodos, por exemplo, o campo potencial (Mataric, 1990). Para isso, criou um conjunto de comportamentos, que na verdade são nada mais que pequenos conjuntos de regras simples de navegação, escritas em um dialeto da linguagem LISP. Estas regras são:

- Passeio (Stroll): Se está muito perto de um obstáculo, pare. Se o obstáculo mais próximo está a pelo menos 2 pés de distância, avance 3 metros. Se está parado e para a esquerda ou para a direita existe espaço para andar, gire 30 graus para o lado correspondente. Em qualquer outro caso, recue 0,4 metros.

- Evitar (Avoid): Se existe um obstáculo a direita, vá para a esquerda. Se existe um obstáculo a esquerda, vá para a direita. Se existe um obstáculo em frente, veja para qual dos lados (esquerda ou direita) pode ir.

- Alinhar (Align): Se o obstáculo está longe demais, gire 30 graus em direção a ele.

- Corrigir (Correct): Se a medida que o robô anda, o obstáculo se afasta para a esquerda ou para a direita mais do que um limite determinado, gire 30 graus na direção contrária.

Neste sistema, existem dois módulos complementares: o de controle de navegação de baixo nível, e o de gerenciamento de alto nível. O módulo de controle de baixo nível é executado diretamente pelas regras contidas nos comportamentos de exploração. $O$ módulo de alto nível consiste dos nós de um grafo que representam os marcos ligados entre si. Uma rota é seguida pelo robô a medida que ele vai na direção do nó que está ativo, que representa o ponto alvo. Um exemplo de navegação é apresentado na Figura 3.4. 


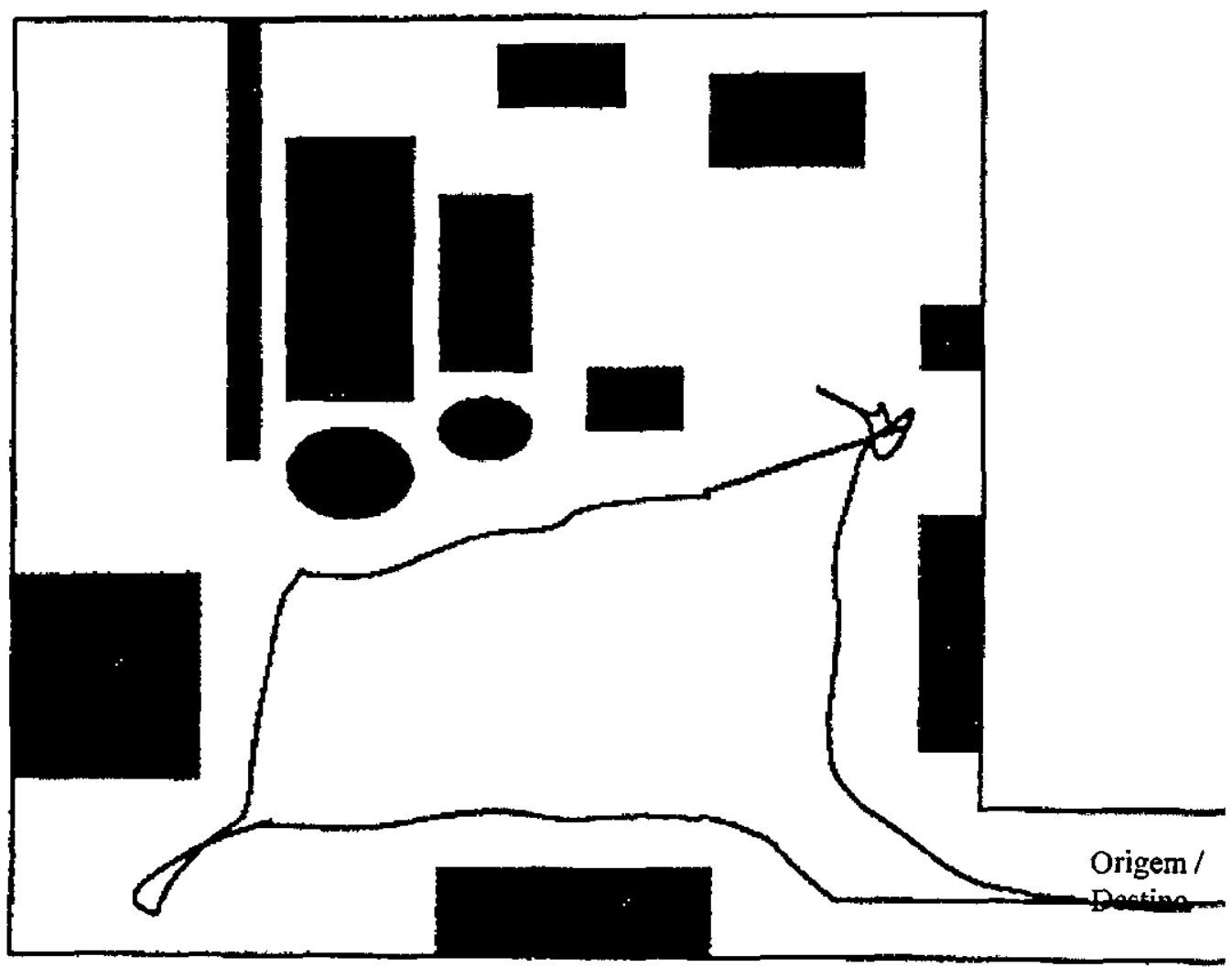

Figura 3.4 - Trajetória executada pelo robô de Mataric.

Se o caminho do robô está obstruído, sua camada de navegação de baixo nível assegura que não haverá colisão girando o robô na direção oposta ao obstáculo. Ao mesmo tempo, a chamada para o alvo força o robô a ir em sua direção. O conflito destas duas motivações resulta no robô pegando o primeiro caminho livre em direção ao alvo. Se o caminho até o alvo está completamente bloqueado, como no caso de um beco sem saída, o robô o abandona depois de certo período de tempo, para evitar oscilações infinitas.

No robô físico, o alvo é definido como um marco a ser alcançado, e é selecionado pressionando-se três botões no topo da cabeça do robô. Os botões permitem escolher um determinado tipo de alvo (como o muro ou corredor mais próximo), o primeiro marco descoberto (o primeiro nó do grafo), ou um marco definido do grafo.

Se um marco específico é selecionado, os marcos intermediários entre o alvo e a posição atual marcam o caminho e, por isso, não há possibilidade de parar em outro ponto parecido, mesmo que haja um dentre os marcos intermediários. 
O robô é capaz de andar em apenas duas direções. $O$ alvo é selecionado pelo usuário através de um monitor, montado no topo do robô. Quando um nó alvo é selecionado, este nó envia sinais aos nós vizinhos da esquerda e da direita. Estes sinais são propagados até atingirem o nó atual, que representa o local no qual o robô está situado. Ao passarem pelos nós intermediários, estes sinais são atualizados, somando-se ao comprimento de cada nó intermediário. Assim, quando o nó atual (aquele em que o robô está) receber estes sinais, ele escolhe aquele com menor distância acumulada, o que gera o menor caminho. O robô então parte do nó atual, onde está inicialmente localizado, e percorre os nós intermediários em seqüêência, até atingir o nó alvo, definido pelo usuário.

\subsubsection{Avaliação Geral}

O robô de Mataric segue paredes, e não toma conhecimento de espaços abertos. Ele trafega em apenas 2 sentidos. Quando se depara com um mundo dinâmico, o sistema se comporta de forma satisfatória, porque ele atualiza o grafo que representa o ambiente, de forma a refletir mais fielmente a situação nova encontrada. Finalmente, as regras contidas nos comportamentos de baixo nível tratam dos obstáculos móveis de forma autônoma, evitando colisões.

Entretanto, sua incapacidade de se localizar em espaços abertos, e seu método de navegação, que não garante que se vá até o alvo, mesmo se um caminho existir, tornam o modelo pouco recomendado para tarefas do mundo real.

\subsection{Considerações Finais}

Os dois paradigmas apresentam vantagens e desvantagens. Enquanto que o paradigma reativo resulta em sistemas mais simples e rápidos, ele tem menor poder de realizar inferências e trabalhar com conhecimentos adicionais. Já os sistemas que seguem o paradigma SMPA dispõe de muito conhecimento, mas são lentos e tem grande dependência de sensores e atuadores bem calibrados, o que é muito difícil de se obter em situações reais.

A combinação dos pontos fortes dos dois paradigmas pode oferecer uma solução melhor do que cada um deles separadamente. No próximo Capítulo, será visto um paradigma que procura realizar isso. 


\section{Paradigma Cognitivo}

\subsection{O Mapa Cognitivo Segundo Tversky}

Tversky (1993) observa que mapas cognitivos são aprendidos adquirindo-se conhecimento de marcos, que são equivalentes a pontos; rotas, que são equivalentes a linhas e panoramas métricos (surveys), que reúnem as informações anteriores.

Entretanto, são apresentadas diversas evidências que depõe contra a existência de um mapa cognitivo métrico implementado nos neurônios do cérebro. De acordo com as evidências coletadas, as pessoas adquirem várias peças de conhecimento a respeito de seus ambientes. Estas peças incluem coleções de viagens realizadas, memória de mapas, fatos e direções verbais, entre outras, ou seja, mais informaçס̃es do que apenas um mapa.

Dois tipos de estruturas são propostas para explicar a armazenagem e utilização de informações de navegação. Um tipo de estrutura que as pessoas usariam para guardar as diversas informaçð̃es relacionadas sobre o ambiente, pode ser chamada de colagem cognitiva. Colagem cognitiva compreendem camadas de informação multimídia, obtidas de diferentes fontes. Estas colagens conteriam figuras, informaçðes parciais e diferentes perspectivas. $O$ outro tipo de estrutura, mais usada para ambientes simples ou facilmente aprendidos, e onde as pessoas possuem uma representação mental acurada do espaço, é chamada de Modelo Espacial Mental. Ao contrário de um mapa topológico, este modelo preserva informaçð̃es métricas. Também ao contrário das colagens cognitivas, ele preserva grosseiramente as relações espaciais.

Tversky cita diversas categorias de erros sistemáticos cometidos pelas pessoas quando submetidas a tarefas de navegação:

1. Representação Hierárquica: Os lugares são organizados hierarquicamente pelas pessoas. Por exemplo, agrupar cidades dentro de um estado e raciocinar com o estado, levando as conseqüências das inferências para as cidades. Certos raciocínios feitos hierarquicamente conduzem a erros de julgamento.

2. Perspectiva Cognitiva: As distâncias julgadas entre marcos próximos são consideradas relativamente maiores que as distâncias entre marcos distantes. 
3. Pontos de Referência Cognitivos: As pessoas tendem a descrever locais menos conhecidos relacionados a marcos mais conhecidos. Ex.: a casa fica perto da catedral. Lembrar locais menos conhecidos relacionando-os a marcos induz distorções particularmente intratáveis em mapas métricos, por exemplo, a distância assimétrica: as pessoas julgam a distância de um local a um marco como sendo menor que a distância de um marco ao local.

4. Alinhamento: Lembrar uma localização em relação a outra pode levar a distorções de direção. Duas localizações alinhadas proximamente tendem a ser agrupadas, do ponto de vista da Gestalt, na memória e então lembradas como mais alinhadas do que realmente são.

5. Características Geográficas Irregulares: Estas características tendem a ser regularizadas. Ex.: as linhas de fronteira de um mapa tendem a ser consideradas como linhas retas. Assim como viradas e ângulos tendem a ser regularizados para ângulos retos.

6. Finalmente, os julgamentos de distância são mais complexos que julgamentos de direção. Eles raramente podem ser conhecidos diretamente e, por isso, encorajam diversos artifícios que podem gerar distorções.

Esta quantidade de erros pode ser gerenciada porque há muito conhecimento sobre o ambiente e pode-se validar uns contra os outros, descartando aqueles mais errados e realizando inferências. Este conhecimento mesmo grosseiro é suficiente para a tarefa de navegação, porque em espaços próximos, os sentidos permitem uma orientação mais precisa.

$\mathrm{Na}$ criação de modelos espaciais mentais, Tversky afirma que é insuficiente lembrar de sucessivas cenas do mundo, porque assim não seria possível o reconhecimento nem a navegação a partir de outros pontos de vista. Faz mais sentido isolar os marcos, e lembrar de suas localizações relativamente uns aos outros e relativamente a um quadro de referência, de modo a que o reconhecimento e a navegação sejam bem sucedidos a partir de diferentes pontos de partida.

Esta integração de conhecimentos no modelo espacial mental ocorreria quando as pessoas lessem descrições espaciais, como instruções de como ir de um lugar a outro, bem como quando navegassem autonomamente pelo mundo. O conceito de Modelo Espacial Mental de Tversky encontra um correlato mais bem desenvolvido na teoria PLAN, discutida na próxima seção. 


\subsection{O Mapa Cognitivo Segundo a Teoria PLAN}

PLAN significa Protótipos, Localizações e Redes Associativas (Prototypes, Location and Association Networks). Apresentado por Chown (Chown et al., 1995), ele é um modelo criado para unificar os dados disponíveis sobre o mapa cognitivo em uma teoria. Teve origem na Universidade de Michigan e partes deste modelo foram implementadas em um robô móvel.

O objetivo primário do modelo PLAN é investigar como o processo de navegação é integrado na cognição geral. Parte-se do pressuposto que a navegação é o propósito fundamental do mapa cognitivo e que por isso o mapa cognitivo tem duas funções: representar os ambientes e usar esta representação para se mover de um lugar a outro.

PLAN se baseia nas capacidades do sistema visual humano e em particular em seus dois subsistemas: o sistema onde, que serve para localizar objetos no espaço e o sistema $o$ que, que serve para identificar ou reconhecer objetos.

Assim, o problema de navegação humana é dividido em 4 sub problemas:

1. Identificação de Marcos: Marcos são características específicas de lugares, usados para determinar a orientação e a localização atual. Identificar marcos é separar objetos distintivos no ambiente para auxiliar no planejamento de rota e serem reconhecidos enquanto a rota escolhida for atravessada.

2. Seleção de Caminho: Tarefa de escolher uma rota até o alvo. Um caminho, ao contrário de uma direção, é mais algorítmico. Um caminho é uma série de lugares ou marcos que levam do lugar atual até o alvo. Para seguir um caminho, segue-se de marco a marco em sequiência.

3. Seleção de Direção: Tarefa de escolher uma direção para navegar. Se o alvo está ao alcance dos sensores, uma direção razoável a tomar é ir diretamente a ele. No caso de alvos fora do alcance dos sensores, o problema é mais complicado. Pode ser que seja necessária uma série de voltas e mudanças na direção.

4. Panorama Ambiental Abstrato: É a generalização do conceito de rota. Um panorama representa um espaço maior que aquele que pode ser visto de apenas um ponto. Este panorama pode tornar o raciocínio sobre o ambiente em larga escala mais simples.

A teoria PLAN se apoia em dados sobre evolução, fisiologia e desenvolvimento. Em particular, os dados a respeito do desenvolvimento humano sugerem uma estrutura básica e uma seqüência de desenvolvimento para o mapa cognitivo: Marcos, Rotas e Panoramas.

No nível de marcos, é aprendida uma estrutura topológica formada pelos marcos observados. Esta estrutura pode ser representada como um grafo, onde os nós são os marcos e 
os arcos indicam os marcos adjacentes. Para usar esta estrutura, extrai-se uma seqüência de marcos que levem do ponto atual até o alvo desejado.

No nível de mapas de rota, o mapa cognitivo parece consistir de uma grande coleção de rotas, que são seqüências de lugares que já foram experimentados. Cada um destes lugares tem uma estrutura direcional em que são codificadas direções relativas entre os marcos. Com esta estrutura disponível para a navegação, o papel do marco passa de destino para marcador uma viagem não é mais uma série de marcos, mas uma série de lugares, e os marcos são úteis para manter a trilha da posição atual.

Quando já se conhece bem o ambiente, mapas de panorama são desenvolvidos e podese visualizar a direção necessária para atingir o alvo, mesmo quando ele está longe.

PLAN assume esta visão, baseada em dados a respeito do desenvolvimento humano, e constrói o modelo do mapa cognitivo também em três níveis: o de marcos, o de rotas, e o de panoramas abstratos.

Para navegar, PLAN dispõe de navegação topológica (baseada em marcos) e navegação locacional (baseada em lugares). Apenas quando o ambiente se toma familiar é que fica disponível um mapa panorâmico, que também pode ser usado em navegação.

Kortenkamp, um dos criadores do modelo PLAN, cita as características chave do mapa cognitivo, conforme delineado por cientistas de IA e psicologia:

1. Mapas Cognitivos são construídos em uma seqüência: identificação de marcos, mapas de rotas de seqüências de marcos (topologia) e, finalmente, um mapa de ambiente completo (espacial).

2. Mapas Cognitivos são qualitativos ou aproximados, ao invés de quantitativos e precisos. Isto porque quando é necessária precisão, a realimentação do ambiente é utilizada.

3. Mapas Cognitivos são hierárquicos. O ambiente é dividido em regiões, com algumas poucas rotas principais entre elas.

4. Mapas Cognitivos tem uma polarização "para frente", ou seja, a direção que a pessoa está olhando é o lado de cima do mapa. Quando o mapa é aprendido em uma orientação é difícil transforma-lo em uma orientação diferente.

5. Mapas Cognitivos em indivíduos normais é dominado pelo sistema visual. 


\subsection{O Mapa Cognitivo Segundo a Teoria de Yeap}

Yeap (1988) propõe que o processo de mapa cognitivo é dividido em duas partes ou módulos, fracamente acoplados: o Mapa Cognitivo Bruto, RCM (do inglês Raw Cognitive Map) e o Mapa Cognitivo Completo, FCM (do inglês Full Cognitive Map).

O RCM é criado a partir do sentido mais destacado nas pessoas normais - a visão. Yeap sustenta que é suficiente ter informações sobre a qualidade e arranjo espacial das superficies para cumprir a tarefa de navegação em um dado ambiente. As qualidades de uma superficie (cor, textura, etc.) e o arranjo espacial da mesma estão disponíveis na representação $2 \frac{1}{2} \mathrm{D}$, de Marr. Marr propôs, em sua teoria da visão, que ela poderia ser estudada de maneira modular, produzindo 3 representações:

1. Rascunho primário: torna explícitos os tipos de mudança de intensidade presentes na imagem.

2. Rascunho $2 \frac{1}{2}$ D: torna explícita a forma e a disposição das superfícies relativas ao observador.

3. Representação de modelo 3D: torna explícita a forma tridimensional das superfícies percebidas.

O FCM tem como entrada o mapa RCM e produz como saída várias representações abstratas ou de alto nível, utilizadas para resolver as diferentes tarefas espaciais. Yeap assume que são estas representações, computadas pelo FCM, que serão usadas pelos programas de navegação.

Estas representações abstratas do FCM são computadas sob a ótica conceitual de cada pessoa. Por isso, não é estritamente baseada naquilo que é percebido, sendo assim uma interpretação pessoal.

As pessoas raramente podem ver todo o ambiente em que estão, situadas em apenas uma posição. Pelo contrário, uma pessoa só consegue ter consciência apurada de como é o ambiente andando por ele e explorando-o.

Quando o ambiente não pode ser processado de uma vez só, é necessário uma espécie de buffer, no qual as visões parciais podem ser integradas de modo a formar um todo coerente. Este buffer é chamado de memória para a vizinhança imediata, MFIS (do inglês Memory for one's Immediate Surroundings).

O MFIS integra as visões parciais que chegam, mantendo uma representação unificada da vizinhança do observador. Isto auxilia no reconhecimento das partes imediatas, que o 
observador acabou de passar. Também pode ser usado para construir um mapa global tanto da vizinhança quanto de todos os espaços atravessados, provenientes da memória. Esta operação de construir um mapa a partir da memória é útil no caso da pessoa querer fazer um passeio mental (do inglês mental walking).

Um buffer consistente deste tipo, que possa integrar visões que estão armazenadas na memória estaria sujeito à característica de limite de capacidade da memória de curto prazo. Por isso, ele poderia conter apenas uma área restrita com detalhes ou uma área maior, porém com os detalhes reduzidos. Isto explica por que a organização hierárquica dos lugares é uma necessidade, além de uma conveniência. Mais que isso, as regiões devem ser formadas de maneira auto-organizável, baseada apenas no poder de predição que cada parte da hierarquia oferece. Também explica porque, ainda que fosse desejado, não há um mapa global, mas uma coleção de mapas, formando um atlas cognitivo.

Yeap assume que existem dois tipos de mapas: um deles é o Mapa de Rota, que surge ao se descrever o ambiente em termos de quais ambientes estão conectados entre si. Já se o ambiente for descrito em termos do lay-out espacial dos elementos que compõe cada ambiente, o resultado seria um Mapa Panorâmico (do inglês Survey Map).

Esta conclusão é suportada por experimentos que demonstram a capacidade humana de usar um ou outro, dependendo da tarefa. A teoria de Yeap seria a forma unificada de representação, enquanto que a teoria de Kuipers, analisada na próxima seção, precisa de diferentes representações para cada tipo de mapa. 


\subsection{O Mapa Cognitivo Segundo a Teoria de Kuipers}

A teoria de Kuipers, exposta em Kuipers (1996, 1985, 1983, 1982, 1979, 1978), Kuipers \& Byun (1991) e Kuipers \& Froom (1993), observa que a metáfora de tratar o mapa cognitivo como um "mapa na cabeça" entra em contradição com dois resultados experimentais:

1. O conhecimento espacial pode ser composto de componentes desconexos, com pouca ou nenhuma relação entre si.

2. O conhecimento de rotas pode ser representado assimetricamente. Assim a pessoa consegue seguir em uma direção mas não em outra.

Kuipers trata especificamente de ambientes de larga escala, aqueles cuja estrutura é revelada através da integração das observações locais ao longo do tempo, porque não podem ser percebidos em sua totalidade a partir de um único ponto de observação.

As operações de interesse em um mapa são:

1. Dadas duas localizações, determinar o vetor de posição relativa apontando de um lugar em direção ao outro.

2. Dados dois vetores de posiçбes relativas, determinar sua soma.

3. Dados dois vetores de posições relativas, determinar sua diferença em direção

Kuipers afirma que uma descrição cognitiva espacial consiste de várias representações para o conhecimento espacial:

1. Procedimentos para seguir rotas;

2. Descrições de rede topológicas;

3. Descriç̃os métricas, constituída de vetores de posição relativa.

Um pressuposto comum às outras teorias é que a habilidade de navegar de um lugar a outro é construída sobre uma base de conhecimento de onde as coisas estão. Em contraste, Kuipers sugere "este ensaio afirma que o oposto é verdadeiro: o conhecimento de onde as coisas estão é construido sobre a base do conhecimento de como navegar de um lugar a outro".

Uma observação em que a maioria dos trabalhos concorda é que as descrições espaciais cognitivas e mapas de rascunho são freqüentemente desconectados com regiões cuja estrutura interna é bem definida e razoavelmente acurada, mas cuja relação com o resto da geografia é simplesmente desconhecida. 
Muitos trabalhos verificaram que as pessoas são capazes de desenhar mapas de seus ambientes nos quais todos, ou quase todos os elementos principais estão presentes. Além disso, características do ambiente como conectividade e hierarquia entre os lugares são preservadas. Porém, ao mesmo tempo, as formas dos objetos aparecem distorcidas, e as relações de distância e direção são prejudicadas (Lynch, 1960). As primeiras relações são chamadas topológicas, e as segundas, métricas.

Portanto, em primeiro lugar é possível armazenar relações topológicas sem a informação métrica correspondente, e em segundo lugar as relações métricas são gradativamente acrescentadas até o ponto em que a pessoa conhece tão bem o ambiente, que pode navegar sem a auxílio de realimentação visual. Como o caso de pessoas cegas, ou de pessoas que, com visão normal, conhecem tão bem os ambientes que podem se locomover de olhos fechados.

Se estes exemplos são expressões do mesmo mecanismo, então o desenvolvimento das relações métricas em cima do mapa topológico é o desenvolvimento de um sistema de coordenadas dentro do espaço que compreende o ambiente. Este desenvolvimento seria adaptativo.

A formação destas relações métricas é facilitada em lugares mais conhecidos e mais utilizados. Por isso, não se pode comparar distâncias e direçб̋es entre diferentes lugares com igual facilidade e existem ocasióes em que esta comparação chega a ser impossível.

Estas observaçסes levaram Kuipers a propor que a metáfora seja trocada de mapa na cabeça para atlas na cabeça. Neste atlas, cada folha define um quadro de referência separado. Dentro de cada folha, é possível fazer comparações métricas com facilidade. Já entre duas folhas deste atlas, as comparações são mais difíceis, podendo inclusive ser impossíveis. Este atlas pode conter também folhas desenhadas em escalas diferentes.

A metáfora não pode ser tomada como teoria, porque dentro das folhas valeria a simetria. Se A está a uma distância d de B, B estaria a mesma distância d de A. Isto é geralmente verdade, exceto quando se trata de rotas, que muitas vezes não são simétricas. Ás vezes a pessoa consegue seguir uma rota em um sentido, mas não no sentido oposto.

Kuipers considera, portanto, o conhecimento de rotas como parte integrante do mapa cognitivo. Assim, ele se lança na busca de uma representação que explique ou suporte este ponto de vista. 
A criação do mapa cognitivo conta com dois blocos básicos de construção: as visões e as ações.

A teoria inicia com o observador sendo levado através de uma rota. Esta ação é atômica, ou seja, a teoria original não aborda de forma alguma os mecanismos que levam o observador a esta exploração.

A medida que o passeio vai se desenrolando, o observador liga as visões perceptuais com as ações tomadas (visão $\rightarrow$ ação). Mantendo isso em mente até o próximo ponto de decisão, pode-se criar uma ligação com o resultado da ação([visão ->ação]->visão). Esta segunda ligação suporta a antecipação dos próximos marcos e, assim, uma revisão mental da rota na ausência do ambiente. Uma rota é um conjunto completo destas associações.

A teoria é flexível e suporta estados de conhecimento parcial, que são situações nas quais, devido ao redirecionamento da atenção para tarefas mais urgentes, apenas partes das associações ao longo da rota são formadas. Esta característica leva à propriedade da degradação suave da performance sob limitação de recursos.

Nesta teoria, não é prevista a agregação de lugares em conceitos mais abstratos, nem o reconhecimento de padrões, como na teoria de Yeap.

O próximo passo da teoria é mostrar como as descrições topológicas podem ser adicionadas aos conhecimentos de rota.

Agregando-se as tuplas visão->ação, tem-se uma rota, Esta rota poderá ter atributos próprios, como um nome. Por isso, é considerada uma nova entidade.

De forma análoga, uma descrição de lugar (place) é obtida pela agregação de visões, que são ligadas por ações que envolvem apenas rotação. É como olhar em volta e as visões que se obtém formam um lugar determinado.

Um caminho (path) é obtido pela agregação de visões que ocorrem quando são os lugares ligados por ações envolvendo apenas viagem (travel). É como as visões obtidas quando se atravessa um corredor.

Com estas novas entidades (lugar, caminho e viagem) definidas, é possível relacionalas através de Relações Topológicas, como conexões, definidas entre lugares e caminhos, e Relações de ordem, definidas entre lugares no mesmo caminho.

É importante notar que esta agregação de visões em entidades não é equivalente à montagem de conceitos abstratos hierarquicamente, como na teoria de Yeap. De fato, Kuipers afirma que "é provável que os conceitos de lugar e de caminho não são inventados por cada 
criança, mas foram descobertos durante a evolução das espécies, e são passadas para cada individuo como parte de seu equipamento inato".

Uma vez com uma rede topológica construída, Kuipers nota que é possível utilizar de algoritmos de busca para resolver o problema de encontrar rotas. Este é um tema comum em todas as teorias.

Resta somente determinar como a informação métrica é adquirida. Para isso, nota-se que a informação necessária para derivar as informações de distância e direção estão disponíveis nas descrições de ação: a quantidade de rotação e distância de viagem.

Para formar uma representação métrica a partir destas informações, Kosslyn e Shwartz (1977) propuseram representar posições relativas através da colocação de pontos em um array interno bidimencional, com um processo de exploração restrito. $\mathrm{O}$ quadro de referência está implícito no array.

Uma possibilidade altemativa é a proposta de Marr e Nishihara (1978): uma representação explícita de vetores em termos de tamanho e direção dentro de um quadro de coordenadas especificando explicitamente. Isto requer a descrição de cada vetor de posição relativa, inclusive a distância, direção e quadro de referência.

A decisão sobre a opção correta é difícil, porque ambas suportam a definição, edição e comparação de vetores de posição, podendo inclusive chegar-se a conclusão de que ambas são usadas em diferentes ocasiões.

Quando o problema se tomou a implementação real da teoria, a hipótese de que o observador seria levado através de seu ambiente teve que ser abandonada. Assim, o foco foi desviado para a topologia, em vez da rota.

Para estabelecer uma rede topológica, é preciso que hajam lugares e que estes lugares sejam conectados. Para caracterizar um lugar, criou-se o conceito de lugar distintivo, DP (do inglês Distinctive Place). Cada DP tem uma assinatura - um subconjunto de medidas e valores característicos, que é maximizado no lugar.

Esta assinatura de lugar é definida em termos das entradas sensorias de baixo nível. Quando o robô percebe que está na vizinhança de um lugar que já teve sua assinatura registrada, ele anda em direção ao ponto original da assinatura, onde a leitura de seus sensores estarão mais semelhantes a assinatura original. Esta estratégia é chamada de Hill-Climbing e é usada para eliminar os erros de posicionamento, introduzidos por imperfeições nos sesores e atuadores. 
A estratégia de exploração do ambiente utilizada pelo robô pode ser definida através de um diagrama de estados, conhecido como grafo de transição. Como o próprio Kuipers coloca, "O modelo topológico é construido como um efeito colateral do movimento através deste grafo de transição.".

A estratégia de combinar a operação de Hill-Climbing com a identificação das vizinhanças das assinaturas dos lugares elimina os erros adquiridos durante a viagem de um lugar para outro.

O robô sabe onde está localizado através de informações topológicas e métricas. Topologicamente, o robô pode estar localizado em um lugar distinto (DP), ou pode estar localizado em um caminho, andando em uma dada direção. A informação métrica, quando o robô está em um DP é dada pela leitura dos sensores e pela orientação atual. Já quando o robô está em um caminho, a informação métrica é dada pelo lugar de onde veio, distância percorrida, distância lateral, e orientação atual.

O robô, estando em um lugar, geralmente pode optar por seguir em determinada direção, ao invés das outras. Por isso, ele guarda junto com o lugar as direções que ainda não foram exploradas - esta é a Agenda de Explorações.

Algumas vezes, o robô encontrará lugares cujas assinaturas são iguais. Para verificar se se trata do mesmo lugar ou de lugares diferentes, ele verifica a vizinhança - se é a vizinhança que ele esperava, o lugar já é conhecido e ele está passando de novo. Se, por outro lado, a vizinhança for outra, trata-se de um lugar diferente. Esta estratégia é chamada de procedimento de repetição (em inglês, Rehearse Procedure).

Finalmente, os erros dos sensores são tratados por operações de relaxamento espacial, relaxamento temporal, e teste de hipótese. $\mathrm{O}$ teste de hipótese ocorre quando o robô move-se para mais perto de um espaço aberto, para verificar se não é uma leitura falsa dos sensores. Se for falsa, ao se movimentar, a leitura errada geralmente desaparece.

Apesar de tudo, o robô ainda não trata de mundos dinâmicos, como objetos móveis, e mudanças ambientais, como portas abertas ou fechadas, e não tem mecanismos para perceber se sua posição mudou espontaneamente (Ex.: Alguém afastou o robô um pouco do lugar onde estava).

As informações métricas podem ser usadas para tornar não ambíguos os lugares parecidos, e para melhorar o desempenho da navegação (Ex.: aumentar a velocidade do robô). 


\subsection{Mapa Cognitivo segundo O'Keefe}

Em 1978, O'Keefe e Nadel (O'Keefe \& Nadel, 1978) propuseram uma teoria segundo a qual o hipocampo e áreas associadas no cérebro de ratos seriam os locais onde um mapa cognitivo do lugar onde o animal se encontra estaria representado. A função deste mapa cognitivo seria localizar a posição do animal neste ambiente e armazenar as informações necessárias para o animal atingir um alvo a partir de um ponto inicial qualquer.

Neste mapa cognitivo, o ambiente atual é sempre comparado com o ambiente representado no mapa cognitivo. Quando é detectada uma disparidade entre eles, desde que seja grande o suficiente, inicia-se o comportamento de exploração. Uma disparidade entre o esperado e o real pode acontecer devido a uma mudança no ambiente ou a um ambiente totalmente novo.

Assume-se que a formação hipocampal possa armazenar apenas o ambiente atual, no qual o animal está inserido. Esta representação é de natureza não local. Isto é, está espalhada entre as sinapses dos neurônios. Por isso, diferentes ambientes são representados através do mesmo conjunto de células e estes ambientes diferentes são representados por padrões de atividade diferentes nestas células. Assim, as mesmas células podem participar da representação de numerosos ambientes.

Para instanciar um ambiente, ou seja, um padrão específico de atividade através do mapa cognitivo, é suficiente que parte do ambiente seja reconhecida. Assim o resto também será recuperado.

As unidades de lugar do mapa cognitivo podem codificar a posição do animal em relação às pistas espaciais, o que é uma forma de representação egocêntrica do ambiente. Entretanto, também a relação entre estas pistas espaciais e as pistas de fundo do ambiente são gravadas, o que sugere um tipo de representação alocêntrica do ambiente.

O'Keefe sugere que uma representação do ambiente pode ser dada por uma matriz na qual estão presentes as coordenadas cartesianas $\mathrm{X}, \mathrm{Y}$ dos estímulos. Por outro lado, ele afirma também que é o relacionamento entre os objetos que define o ambiente, e não um conjunto particular de eixos. Por causa deste fato, é possível mudar os eixos de coordenada, sem, contudo, alterar a representação do ambiente. Para que a representação do ambiente esteja sempre atualizada, o animal deve recalcular esta representação constantemente sempre que ele anda através do ambiente. O'Keefe propõe que esta operação é feita deslocando os eixos do quadro de coordenadas de forma que ele permaneça centrado na cabeça do animal. 
Depois do mapa cognitivo ter sido construído, ele pode ser usado para prever as mudanças que irão ocorrer na localização dos objetos, a medida que o animal se move pelo ambiente. Além deste uso, o mapa cognitivo também pode ser usado para a geração da trajetória necessária para se alcançar uma posição alvo a partir da posição atual do animal.

A exploração de um ambiente consiste em, para cada estímulo encontrado, calcular a distância que $o$ animal se encontra dele $(R)$ e $o$ ângulo egocêntrico $(\alpha)$ formado entre $o$ animal e o estímulo. Estes dois parâmetros são associados ao estímulo encontrado.

Se um estímulo do ambiente for comestível ou potável, a teoria prevê que ele será tratado de forma diferente dos demais. Em particular, ele será armazenado fora do hipocampo, em áreas que possam ser acessadas não apenas pelo sistema de mapeamento, mas também pelo sistema de motivação, por exemplo. Assim, quando o animal tem fome ou sede, as coordenadas correspondentes à comida e bebida podem ser enviadas para o hipocampo.

No caso de um ambiente familiar, a ativação de um mapa ou um conjunto de possiveis mapas irá gerar um conjunto específico de distâncias R's ou vários conjuntos de distâncias em resposta às entradas dos estímulos (Q's) e ângulos egocêntricos ( $\alpha$ 's).

No caso de um mapa armazenado, estas R's calculadas irão permitir ao sistema casar as entradas subsequentes e, portanto, atingir algum critério e ser aceito como verídico. No caso de diversos mapas serem armazenados, o sistema tem que ser capaz de selecionar o mapa que representa $o$ ambiente atual entre os mapas armazenados. 


\subsection{Consideraçōes Finais}

Mapa Cognitivo parece que não é o termo mais adequado para descrever a estrutura suportada pelo cérebro do ser humano e dos animais, uma vez que as definições diferem de autor para autor.

Mesmo havendo discordância, mapas cognitivos são a solução encontrada pela natureza para o problema de navegação e isto é um indício de sua eficiência. Mas nem sempre é possível ou produtivo copiar diretamente as soluções da natureza. Um exemplo clássico é a busca da humanidade pela capacidade de voar tentando imitar o vôo dos pássaros.

Para evitar estas armadilhas, o modelo proposto neste trabalho busca inspiração na natureza, ao invés de simplesmente tentar copiar soluções. Mesmo porque, conforme já foi apresentado na Seção 4.1, mesmo os mapas cognitivos naturais estão sujeitos a diversos tipos de falhas e uma cópia sofreria dos mesmos problemas.

Nos próximos Capítulos, será apresentada a proposta, implantação e os resultados de um mapa cognitivo, baseado nas teorias discutidas neste Capitulo, que servem para apoiar um sistema de navegação para robôs móveis. 


\section{Redes Neurais}

\subsection{Introdução}

Redes Neurais Artificiais são modelos de computação inspirados na estrutura e funcionamento do cérebro. Uma Rede Neural é formada por diversas unidades de processamento, análogos aos neurônios naturais. Estas unidades estão ligados por conexões que simulam as sinapses que ocorrem no sistema nervoso (Gallant, 1995; Freeman \& Skapura, 1991; Anderson \& Rosenfeld, 1988).

Existem diversas classificações para as Redes Neurais. Uma das mais utilizadas diz respeito ao método usado para treiná-las. Se para treinar uma Rede Neural são fornecidos exemplos de entradas e saídas desejadas e a rede ajusta sua saída real de modo a ser coerente com a saída desejada, a rede é chamada supervisionada.

Se, por outro lado, são fornecidos à rede apenas exemplos de entrada e, deixa-se que ela realize uma partição, ou agrupamento nos dados por si, a rede é chamada não supervisionada.

Finalmente, se a rede agir sobre os exemplos de entrada, e quando ela apresenta sua saída, indica-se se a ação escolhida foi satisfatória ou não, ela é chamada de rede com aprendizado por reforço.

Neste Capítulo são apresentados exemplos de Redes Neurais supervisionadas e não supervisionadas. Estas redes podem ser utilizadas para implementar o mapa cognitivo proposto. 


\subsection{Aprendizado Associativo}

As Redes Neurais são formadas por diversos elementos simples de processamento chamados neurônios. A Figura 5.1 apresenta a representação de um destes neurônios artificiais.

$\mathrm{Na}$ figura, o neurônio é o círculo grande com o símbolo sigma dentro. Este neurônio recebe sinais provenientes de outros neurônios através das setas localizadas a sua esquerda. Estas setas representam as conexões. Cada conexão tem um peso, denominado $Z_{i}$ na figura. Os sinais provenientes de outros neurônios são multiplicados pelos pesos z, antes de atingirem o neurônio.

O neurônio realiza uma operação de soma dos sinais que chegam a ele (por isso o símbolo sigma no neurônio). O somatório é então passado por uma função chamada função de transferência. Esta função é representada pela caixa do lado direito do neurônio na Figura. Esta função pode ser linear, ou não linear. O resultado desta função é a saída do neurônio, chamada y na figura. Esta saída por sua vez, vai ser aplicada a outros neurônios.

Uma Rede Neural possui uma regra de "treinamento", pela qual os pesos das conexões entre os neurônios são ajustadas de acordo com os dados fornecidos para a rede.

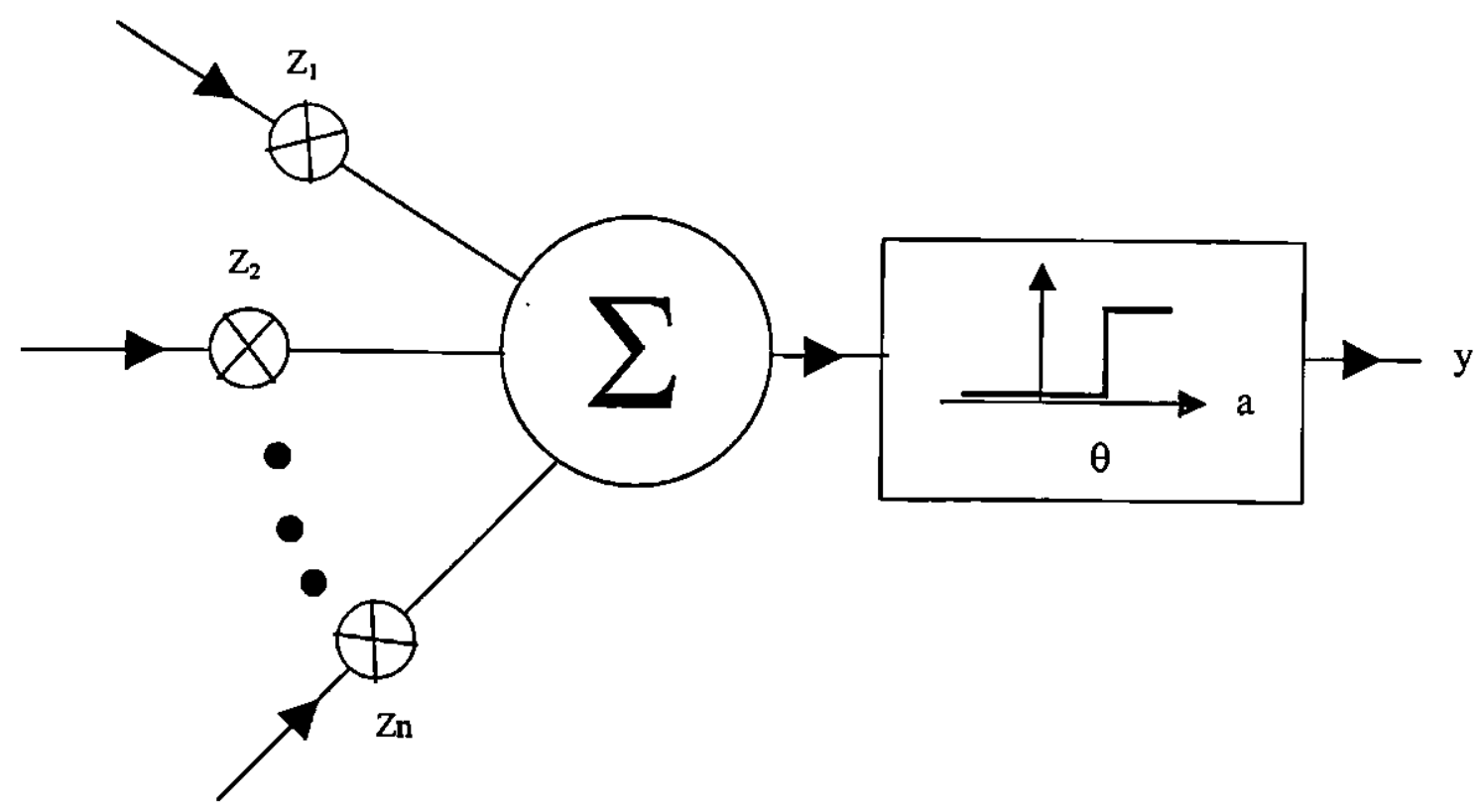

Figura 5.1: Nenrônio Artificial 
O paradigma de aprendizado mais simples é aquele em que há associação entre dois eventos que ocorrem em instantes muito próximos (James, 1988). Este tipo de aprendizado é chamado de condicionamento clássico. Sobre este tipo de aprendizado associativo, Donald Hebb (Hebb, 1949) estabeleceu seu famoso postulado: "Quando o axônio de uma célula A está próximo o bastante para excitar uma célula $B$, e repetidamente ou persistentemente toma parte em sua ativação, algum processo de crescimento ocorre em uma ou em ambas as células, de modo que a eficiência da célula A no disparo de B é aumentada".

Grossberg iniciou o desenvolvimento de uma teoria quantitativa do aprendizado associativo com Redes Neurais não supervisionadas que operavam em tempo real, a partir de uma modelagem quantitativa do postulado de Hebb.

A Rede Neural utilizada nesta modelagem está representada na Figura 5.2, que apresenta uma célula $v_{i}$ ligada a outra célula $v_{j}$, através da conexão $e_{i j}$. A atividade da célula $v_{i}$ é chamada de $\mathrm{x}_{\mathrm{i}}$. A atividade da célula $v_{\mathrm{j}}$ é chamada $\mathrm{x}_{\mathrm{j}}$, e o valor do peso da conexão $e_{\mathrm{ij}}$ entre as células é chamado $z_{i j}$. Cada barra representa a ativações de uma célula. Nesta figura, a atividade $\mathrm{x}_{\mathbf{i}}$ é maior que a atividade $\mathrm{x}_{\mathbf{j}}$.

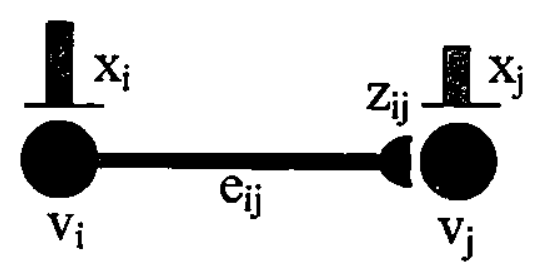

Figura 5.2 - Os neurônios $v_{i}$ e $v_{j}$ ligados através da sinapse $e_{i j}$.

A regra de aprendizado que Grossberg usou foi chamada, porém, de não-hebbiana. Isto porque a regra estendia o postulado de Hebb, já que além do efeito de associação, também o esquecimento era modelado (Hervey, 1994).

Formalmente, a forma mais simples de expressar esta regra de aprendizado é dada pela Equação 5.1. (Grossberg, 1982).

$$
\frac{d}{d t} z_{i j}=-A z_{i j}+f \mathrm{I}\left(x_{i}\right) f 2\left(x_{j}\right)
$$


$\mathrm{Na}$ Equação $5.1, \mathrm{~d} z_{\mathrm{ij}} / \mathrm{dt}$ denota a taxa de variação do peso $z_{\mathrm{ij}}$ entre os neurônios $v_{\mathrm{i}}$ e $v_{j}$, que apresentam respectivamente as ativações $x_{i}$ e $x_{j}$. $O$ parâmetro $A$ é uma pequena taxa de esquecimento, e f1 e f2 são funções de sinal não negativo monotonicamente não decrescentes (em geral, uma função sigmóide).

A regra diz que se os neurônios $v_{i}$ e $v_{j}$ forem ativados ao mesmo tempo, a conexão entre eles aumentará. Se eles não dispararem juntos, o peso entre eles irá gradualmente perder sua força.

Uma célula pode estar ligada a várias outras, através de conexões adicionais. Cada conexão obedece esta lei associativa. Ligadas desta forma, o conjunto de células é chamado de outstar (Grossberg, 1982).

A Figura 5.3 mostra uma rede outstar. Na parte (a) as ativações recebidas pelas células estão representadas pelas setas nomeadas com a letra I. Na parte (b) da figura, a célula $v_{\mathbf{J}}$ é chamada fonte da outstar, e cada $v_{i}, i \neq 1$, é chamada dreno da outstar. O conjunto $B$ de todos os drenos é chamado borda. Na parte (a) da figura, a célula $V_{A}$ é a fonte e as células $V_{B}, V_{C}$, $V_{D}$, e $V_{E}$ são os drenos. A rede outstar tem este nome porque pode ser redesenhada em forma de estrela, como apresentado na parte (b).

(a)

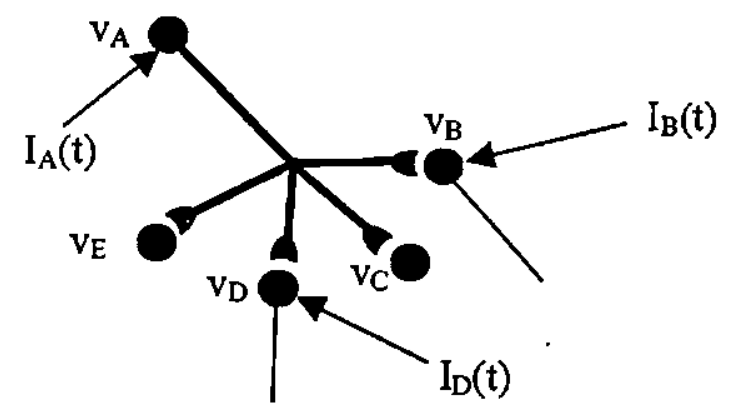

Figura 5.3 - (a) A Outstar (b) Outstar em forma de estrela.

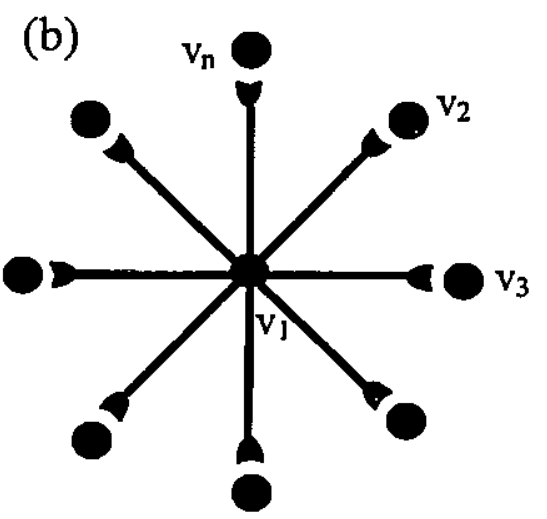




\subsection{Rede ART1 (Adaptive Resonance Theory)}

As redes ART foram idealizadas e desenvolvidas por Stephen Grossberg (Grossberg, 1988). ART significa Teoria da Ressonância Adaptativa (do inglês Adaptive Resonance Theory). Com base nesta teoria, uma grande família de Redes Neurais foi desenvolvida, incluindo ART1, ART2, ART3, ARTMAP, Fuzzy ARTMAP e muitas outras. Neste trabalho é enfocada apenas a Rede ART1, porque ela é utilizada na implementação do sistema proposto.

Em uma rede ART, a informação gerada pelos neurônios de saída é refletida para frente e para trás entre as camadas. Se o padrão correto se desenvolve, uma oscilação estável é obtida, que é a ressonância na rede.

Durante o período de ressonância pode ocorrer o aprendizado ou adaptação. Antes da rede atingir a ressonância, nenhum aprendizado acontece, porque o tempo requerido para ocorrer mudanças permanentes nos pesos dos neurônios é muito maior do que o tempo que a rede leva para atingir a ressonância.

Um estado ressonante pode ser atingido de duas formas. Se a rede aprendeu previamente a reconhecer o vetor de entrada apresentado, então um estado ressonante será atingido rapidamente. Durante a ressonância, o processo de adaptação irá reforçar a memória do padrão armazenado.

Se o padrão de entrada não é imediatamente reconhecido, a rede irá procurar rapidamente por padrões armazenados, procurando um que case. Se nenhum casar, a rede entra em um estado ressonante no qual o padrão será armazenado pela primeira vez. Assim, a rede responde rapidamente a dados aprendidos previamente e ainda permanece capaz de aprender quando padrões novos são apresentados.

A Figura 5.4 apresenta uma Rede ARTl. Ela é composta por duas camadas de neurônios. A camada F1 é a camada de entrada e a camada F2 é a camada de saída. Existem conexões para frente, da camada $F 1$ para a F2, e também conexões para trás, da camada F2 para a camada F1. O vetor de entrada é composto de valores binários 0 ou 1, e é apresentado a camada F1. 


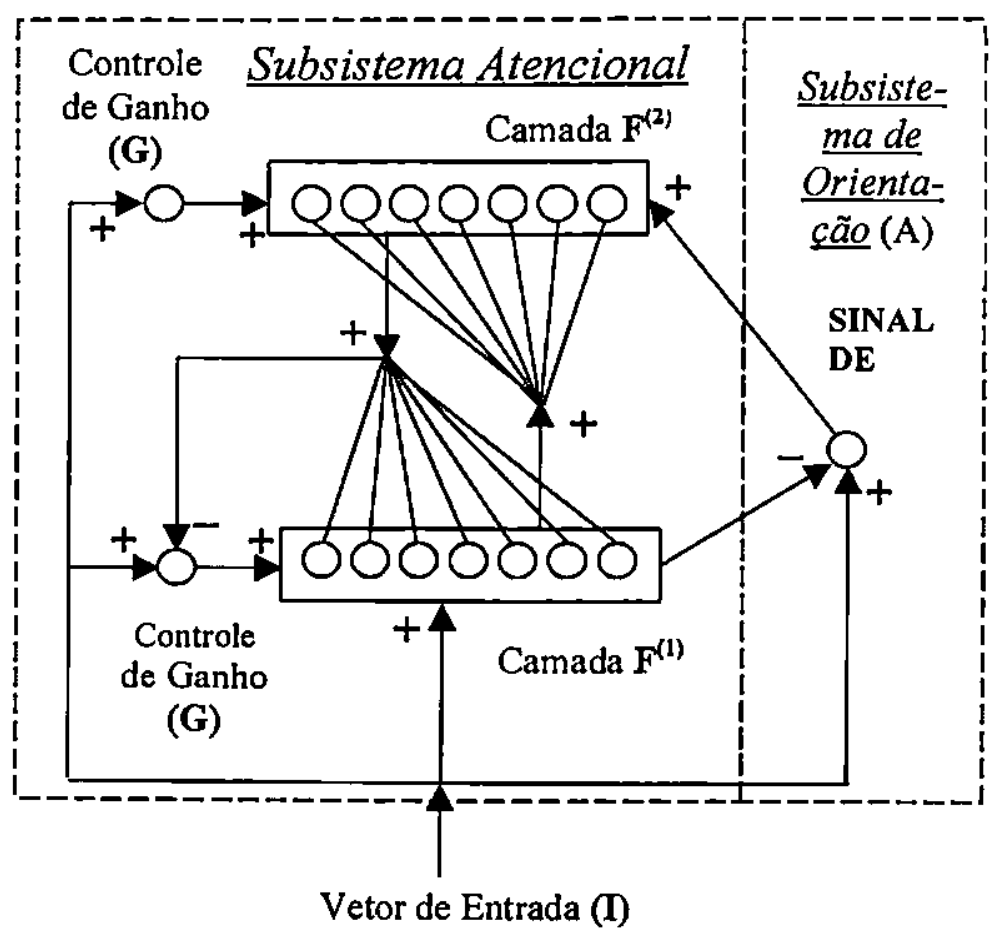

Figura 5.4 - Uma Rede Neural ART1.

Inicialmente, um padrão de entrada $I$ é apresentado às unidades da camada $F^{(1)}$. Cada componente do vetor de entrada é associado a um cada nó da camada de entrada.

Um padrão de ativação $\mathbf{X}$ é produzido pela camada $F^{(1)}$. Esta camada realiza a operação de normalização do padrão de entrada, e o valor de cada elemento desta camada é calculado através da Equação 5.2:

$$
x_{1 i}=\frac{I_{i}}{1+A_{1}\left(I_{i}+B_{1}\right)+C_{1}}
$$

Na qual:

$I_{1}$ é o padrão recebido pelo neurônio ( 1 ou 0 );

$A_{1}, B_{1}$ e $C_{1}$ são constantes para a camada $F^{(1)}$, determinadas de forma empírica. 
O mesmo padrão de entrada excita tanto o Subsistema de Orientação (A), quanto o Controle de Ganho (G) (as conexões para G não são mostradas na Figura 5.6, para maior clareza do diagrama).

Um padrão de saída $\mathrm{S}$ resulta em um padrão inibitório, que também é enviado para $\mathrm{A}$. A rede é estruturada de modo que este sinal inibitório cancela exatamente o efeito excitatório do sinal de I, para que A permaneça inativo. Cada elemento do padrão de saída é calculado de acordo com a Equação 5.3:

$$
s_{i}=h\left(x_{1 i}\right)= \begin{cases}1 & \text { se } x_{1 i}>0 \\ 0 & \text { se } x_{1 i} \leq 0\end{cases}
$$

$O$ subsistema $G$ também fornece um sinal excitatório para $\mathrm{F}^{(1)}$. O mesmo sinal é aplicado a cada nó da camada, e por isso é conhecido como sinal não específico.

$A$ apresentação de $\mathbf{X}$ em $F^{(1)}$ resulta em um padrão de saída $S$, que é enviado através das conexões, para $\mathrm{F}^{(2)}$. Cada unidade em $\mathrm{F}^{(2)}$ recebe todo o vetor de saída $S$, de $\mathrm{F}^{(1)}$, através de conexão ponderada pelos pesos. As unidades em $\mathrm{F}^{(2)}$ calculam seus valores totais de entrada somando os valores de entrada pelos pesos das conexões associadas, de acordo com a Equação 5.4:

$$
T_{j}=\sum_{l=1}^{M} s z_{j l}
$$

Em resposta às entradas de. $\mathrm{F}^{(\mathrm{I})}$, um padrão de atividade $\mathbf{Y}$ se desenvolve através dos nós de $\mathrm{F}^{(2)}$. $\mathrm{F}^{(2)}$ é uma camada competitiva onde os neurônios competem para definir qual gera a maior saída. Como resultado, apenas um nó em $\mathrm{F}^{(2)}$ tem uma saída diferente de zero, como pode ser observado na Equação 5.5:

$$
u_{j}= \begin{cases}1 & \text { se } T_{j}=\max \left\{T_{k}\right\} \forall k \\ 0 & \text { caso contrário }\end{cases}
$$

Assume-se que o nó vencedor é uj. $\mathrm{O}$ padrão de atividade $\mathbf{Y}$ resulta em um padrão de saída $\mathbf{U}$, de $\mathrm{F}^{(2)}$. Este padrão de saida é enviado como um sinal inibitório para o subsistema de 
controle de ganho. O controle de ganho é configurado de forma que se ele receber qualquer sinal inibitório de $\mathrm{F}^{(2)}$, ele pára de funcionar. $\mathrm{O}$ padrão $\mathrm{U}$ também se torna um segundo padrão de entrada para as unidades $F^{(1)}$. O padrão $\mathbf{U}$ é transformado pelas conexões que ligam $F^{(2)}$ a $F^{(1)}$. Este padrão transformado é chamado V, e é obtido pela Equação 5.6:

$$
V_{l}=\sum_{j=1}^{N} u j w_{l j}
$$

Na qual:

$\mathrm{W}_{\mathrm{ij}}=$ peso da conexão entre o neurônio $\mathrm{i}$ com o neurônio $\mathrm{j}$.

Portanto, pode-se observar que existem 3 fontes de sinais para a camada $F^{(1)}$, mas somente 2 são usados em um dado momento. As unidades em $\mathrm{F}^{(1)}$ e em $\mathrm{F}^{(2)}$ são construídas de modo a se tornarem ficarem ativas somente se duas das três possiveis fontes de sinais estiverem ativas. Esta é a chamada regra da maioria (também conhecida como regra 2/3).

Por causa da regra da maioria, somente aqueles nós de $\mathrm{F}^{(1)}$ que recebem sinais tanto de $I$ quanto de $V$ estarão ativas. $O$ padrão que permanece em $F^{(1)}$ é a interseção de $I$ e $V(I \cap V)$. As novas atividades de $\mathrm{F}^{(1)}$ são calculadas de acordo com a Equação 5.7:

$$
x_{1 /}=\frac{I_{1}+D_{1} V_{1}-B_{1}}{1+A_{1}\left(I+D_{1} V_{i}\right)+C_{1}}
$$

Na qual:

$A_{1}, B_{1}, C_{1}, D_{1}$ são constantes determinadas empiricamente

As novas atividades são calculadas de acordo com a Equação 5.3. A seguir, é calculado o grau de casamento entre o padrão de entrada e os sinais de feedback, recebidos de $\mathrm{F}^{(2)}$, pela Equação 5.8:

$$
\frac{|S|}{|I|}=\frac{\sum_{i=1}^{M} s i}{\sum_{i=1}^{M} I I}
$$


Se $|S| / \mid I<\rho$ (no qual $\rho$ é um parâmetro ajustado pelo usuário), $v_{\mathrm{j}}$ é marcado como inativo. Como conseqüência as saidas de $F^{(2)}$ são zeradas, e o padrão de entrada é novamente apresentado a $\mathrm{F}^{(1)}$, repetindo-se todo o processo.

Por outro lado, se $|S| /|\Pi| \geq \rho$, os pesos da camada $F^{(1)}$ para a camada $F^{(2)}$, apenas da unidade $v_{\mathrm{j}}$ são atualizados, de acordo com a Equação 5.9:

$$
z_{\mathrm{j}}= \begin{cases}L / L-1+|S| & \text { se } v_{\mathrm{i}} \text { está ativo } \\ 0 & \text { se } v_{\mathrm{i}} \text { está inativo }\end{cases}
$$

Finalmente, atualiza-se os pesos que vão da camada $F^{(2)}$ para $F^{(1)}$, do nó $v_{\mathrm{J}}$ de $F^{(2)}$, para todas as unidades de $F^{(1)}$, de acordo com a Equação 5.10:

$$
z_{i j}= \begin{cases}1 & \text { se } v_{i} \text { está ativo } \\ 0 & \text { se } v_{i} \text { está inativo }\end{cases}
$$

Para tratar do próximo padrão, restauram-se todas as unidades inativas de $F^{(2)}$, e o processo é repetido desde o início.

\subsection{Redes Perceptron Multi Camadas (MLP)}

Algumas Redes Neurais são modelos de Redes Neurais biológicas, como por exemplo as redes ART, outras não. Um modelo de rede que não é biologicamente plausível, mas que ainda assim tem larga utilização prática compreende as redes Perceptron Multi Camadas, ou MLP (do inglês, Multi Layer Perceptron).

Esta Rede Neural faz parte da categoria de redes supervisionadas. Os dados utilizados para o treinamento desta Rede são pares de entrada-saída, e a regra de treinamento é chamada de Regra Delta Generalizada (do Inglês Generalized Delta Rule), ou apenas Regra Delta.

Uma rede MLP é formada por um grupo de neurônios. Cada neurônio é uma simples unidade que realiza a soma de suas entradas, e cuja saída obedece a Equação 5.11: 


$$
y_{j}=f\left(\sum_{i=1}^{N} w_{j i} * x_{i}+\theta_{j}\right)
$$

$\mathrm{Na}$ qual:

$\mathrm{y}_{\mathrm{j}}=$ saída do neurônio $\mathrm{j}$

$\mathrm{f}()$ = função de ativação, geralmente a função sigmóide

$w_{i j}=$ peso entre o neurônio $i$ e o neurônio $j$

$\mathrm{x}_{\mathrm{i}}=$ saída do neurônio $\mathrm{i}$

$\theta_{\mathrm{j}}=$ limiar (threshold) do neurônio j

A Regra Delta Generalizada também é conhecida como Retropropagação, ou BP (do inglês Backpropagation).

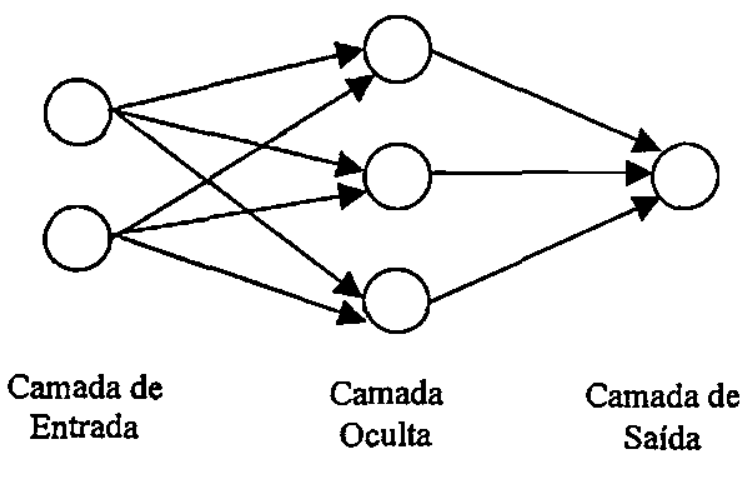

Figura 5.8: Rede Neural MLP.

Na Figura 5.8, a camada de entrada não realiza processamento, ela apenas distribui o padrão de entrada para a próxima camada da rede. As próximas camadas são as camadas ocultas. Estas camadas são responsáveis por criar representações internas dos padrões de entrada. Uma Rede MLP pode ter mais de uma camada oculta, cada uma conectada a anterior. A saída da última camada oculta é propagada para a camada de saída, que dará o resultado final. O resultado real, fornecido pela rede, é entăo comparado com o resultado desejado, fornecido pelo usuário. Possíveis erros são então corrigidos, através do ajuste das conexões existentes entre os neurônios, aplicando a Equação 5.12 nas conexões da camada de saída: 


$$
w_{j k}(t+1)=w_{j k}(t)+\eta\left(y_{p k}-o_{p k}\right) i_{p j}
$$

Na qual:

$w_{j k}(t+1)=$ peso da conexão entre o neurônio j e o neurônio $k$ no instante $t+1$

$w_{j k}(t)=$ peso da conexão entre o neurônio $j$ e o neurônio $k$ no instante $t$

$\eta=$ taxa de aprendizado

$\mathrm{y}_{\mathrm{pk}}=$ saída real do neurônio $\mathrm{k}$, para o padrão $\mathrm{p}$

$\mathrm{o}_{\mathrm{pk}}=$ saída desejada do neurônio $\mathrm{k}$, para $\mathrm{o}$ padrão $\mathrm{p}$

$\mathrm{i}_{\mathrm{pj}}=$ derivada do erro

Para treinar uma rede BP, utiliza-se o seguinte algoritmo (Freeman \& Skapura, 1991):

1. Aplicar o vetor de entrada $x_{p}=\left(x_{p 1}, x_{p_{2}}, \ldots, x_{p N}\right)$ às unidades de entrada

2. Calcular os valores de entrada totais para as unidades da camada oculta:

$n e t_{p j}^{h}=\sum_{i=1}^{N} w_{j i}^{h} x_{p i}+\theta_{j}^{h}$

3. Calcular as saídas da camada oculta:

$i_{p j}=f_{j}^{h}\left(\right.$ net $\left._{p j}^{h}\right)$

4. Mover-se para a camada de saída. Calcular os valores de entrada total para cada unidade:

$n e t_{p k}^{o}=\sum_{j=1}^{L} w_{k j}^{o} i_{p j}+\theta_{k}^{\circ}$

5. Calcular as saídas:

$o_{p k}=f_{k}^{o}\left(n e t_{p k}^{\circ}\right)$

6. Calcular os termos de erro para as unidades de saída:

$\delta_{p k}^{\circ}=\left(y_{p k}-o_{p k}\right) f_{k}^{0^{\circ}}\left(n e t_{p k}^{o}\right)$

7. Calcular os termos de erro para as unidades ocultas

$\delta_{p j}^{h}=f_{j}^{h^{\prime}}\left(n e t_{p j}^{h}\right) \sum_{k} \delta_{p k}^{o} w_{k j}^{o}$ 
Notar que os termos de erro nas unidades ocultas são calculados antes dos pesos das conexões para as unidades da camada de saída serem atualizadas.

8. Atualizar os pesos na camada de saída:

$$
\mathcal{W}_{k j}^{o}(t+1)=w_{k j}^{o}(t)+\eta \delta_{p k}^{o} i_{p j}
$$

9. Atualizar os pesos na camada oculta:

$$
w_{j i}^{h}(t+1)=w_{j i}^{h}(t)+\eta \delta_{p j}^{h} x_{i}
$$

10. Calcula-se o termo de erro global para saber quanto a rede está aprendendo:

$$
E_{p}=\frac{1}{2} \sum_{k=1}^{M} \delta_{p k}^{2}
$$

Uma Rede Neural do tipo MLP foi utilizada para a implementação do Módulo de Mapa Cognitivo, em lugar da Rede Neural VAM, que será discutida na próxima seção. Os motivos para esta troca são discutidos no Capítulo 8. 


\subsection{Redes VAM (Vector Associative Maps)}

A Rede Neural VAM é uma Rede desenvolvida originalmente como modelo da geração e controle de movimentos do braço de humanos e de animais. Posteriormente, serviu de base para a construção de diversos sistemas, inclusive o NETMORC, para controle de robôs móveis (Zalama et al., 1995).

A idéia, que foi emprestada de Piaget, é a de reação circular. Inicialmente, uma criança pequena gera movimentos espontâneos, aleatórios, que os olhos seguem incondicionalmente. Quando o movimento termina, a mão está em determinado ponto no espaço, bem como o olho está em determinado ângulo em relação a cabeça. A posição dos olhos fica então associada a posição da mão. Esta posição dos olhos, bem como a posição da cabeça, pode ser usada para derivar informações suficientes para localizar um ponto em 3D, conforme explica Guenther (Guenther et al., 1992). Muitos movimentos deste tipo são repetidos e cada vez os olhos são fixos em um ponto no espaço $3 \mathrm{D}$, no qual se encontra a mão. Outros modelos propõem esquemas semelhantes para a localização egocêntrica e alocêntrica (Amorim \& Stucchi, 1997; Amorim et al., 1996; Deneve \& Pouget, 1997).

Mais tarde, quando após crescida, a criança quer levar a mão a um determinado ponto para o qual está olhando, a posição dos olhos serve como uma pista e a posição da mão, previamente associada a esta posição dos olhos é recuperada. Esta posição da mão é o objetivo.

A Figura 5.9 apresenta o esquema de uma Rede Neural VAM. A mão sempre está localizada em algum ponto do espaço. Este lugar é chamado de Comando de Posição Presente, PPC, (do inglês, Present Position Command), e a posição desejada da mão é chamada de Comando de Posição Alvo, TPC, (do inglês, Target Position Command). Estes dois sinais são enviados ao módulo DV, que subtrai o PPC do TPC. O canal NP é ativado para permitir ocorrer a fase de aprendizado. Tudo o que se tem a fazer é atualizar gradualmente a posição presente da mão, para que ela se aproxime da posição alvo desejada. Esta operação é feita calculando-se a diferença entre as duas posições e movendo-se o braço proporcionalmente a esta diferença. Quando a diferença entre posição desejada (TPC) e posição atual (PPC), de modo que o DV é zero, então o objetivo foi atingido e nenhum movimento adicional é necessário. 


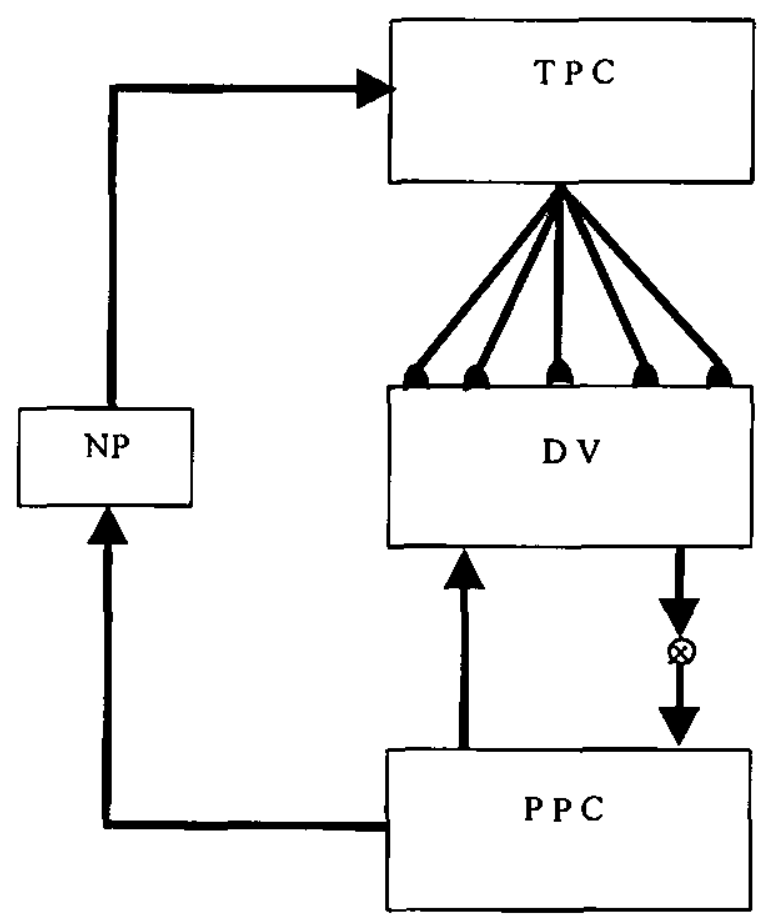

Figura 5.9 - Diagrama mostrando os módulos do modelo VAM.

As Equações originais do modelo VAM, conforme apresentadas por Gaudiano \& Grossberg (1991), são:

Comando de Posição Presente (PPC):

$\frac{d P_{i}^{+}}{d t}=\left(1-P_{i}^{+}\right)\left(G\left[V_{i}^{+}\right]^{k}+O_{2 i-1}^{+}\right)-P_{i}^{+}\left(G\left[V_{i}^{-}\right]^{k}+O_{2 i}^{+}\right)$

Na qual:

$\mathrm{P}_{\mathrm{i}}^{+}$é a atividade no PPC;

$\mathrm{G}\left[\mathrm{V}_{\mathrm{i}}^{+}\right]$e $\mathrm{G}\left[\mathrm{V}_{\mathrm{i}}^{-}\right]$são os componentes agonista e antagonista respectivamente;

$\mathrm{O}_{2 \mathrm{i}-1}^{+}$e $\mathrm{O}_{2 \mathrm{i}}^{-}$são as entradas aleatórias geradas na fase de treinamento

Vetor de Diferenças (DV):

$\frac{d V_{i}^{+}}{d t}=\alpha\left(-V_{i}^{+}+T_{i}^{+} Z_{l}^{+}-P_{l}^{+}\right)$

$\mathrm{Na}$ qual: 
$\mathrm{V}_{\mathrm{i}}^{+}$é a atividade em DV;

$\alpha$ é a taxa com que o DV irá rastrear a diferença entre o TPC e o PPC;

$\mathrm{T}_{i}^{+} * \mathrm{Z}_{i}^{+}$é a cópia filtrada da atividade do TPC;

$\mathrm{P}_{\mathrm{i}}^{+}$é a atividade do PPC.

Memória de longo prazo (LTM):

$\frac{d Z_{i}^{+}}{d t}=g_{n} f\left(T_{i}^{+}\right)\left(-\beta Z_{i}^{+}-\gamma V_{i}^{+}\right)$

Na qual:

$\mathrm{Z}_{\mathrm{i}}^{+}$é o peso adaptativo, entre o componente $\mathrm{T}_{\mathrm{i}}^{+}$do TPC e o componente $\mathrm{V}_{\mathrm{i}}^{+}$do DV;

$\mathrm{g}_{\mathrm{n}}$ é 0 ou 1, se o portão de aprendizado estiver desativado ou ativado respectivamente;

$f\left(T_{i}\right)=1$ se $T_{i}>0$ e 0 se $T_{i}=0$;

$\beta$ e $\gamma$ são taxas de decaimento de atividade;

$\mathrm{V}_{\mathrm{i}}^{+}$é a atividade em $\mathrm{DV}$.

Comando de Posição Alvo (TPC):

$\frac{d T_{i}^{+}-}{d t}=\delta\left[-\varepsilon T_{i}^{+}+\left(1-T_{i}^{+}\right)\left(E_{i}^{+}+F_{i}^{+}+T_{l}^{+}\right)-T_{i}^{+}\left(E_{i}^{-}+F_{i}^{-}+T_{i}^{-}\right)\right]$

Na qual:

$\mathrm{T}_{\mathrm{i}}^{+}$é a atividade no TPC;

$-\in \mathrm{T}_{\mathrm{i}}$ é um pequeno termo de integração leaky;

$\left(E_{i}^{+}\right.$e $\left.E_{i}\right)$ instanciam novos comandos que vem de outras modalidades, como visão;

$\left(\mathrm{F}_{\mathrm{i}}^{+}\right.$e $\left.\mathrm{F}_{\mathrm{i}}{ }^{\mathrm{i}}\right)$ são entradas que vem do PPC.

Já as Equações adaptadas por Srinivasa \& Sharma (1998) são:

Vetor de Diferenças (DV): 


$$
\Delta I_{1}=\theta_{L}+W_{1}^{L} V^{L}+W_{1}^{R} V^{R}-I_{1}
$$

Na qual:

$\Delta \mathrm{I}_{1}=$ Atividade na parte 1 do $\mathrm{DV}$;

$\theta_{\mathrm{L}}=$ Atividade atual do TPC;

$\mathrm{W}^{\mathrm{L}} \mathrm{V}^{\mathrm{L}} \mathrm{e} \mathrm{W}^{\mathrm{R}} \mathrm{V}^{\mathrm{R}}=$ Atividade devido a ativação dos mapas espaciais, multiplicado pelos pesos; $I_{1}=$ Sinal de treinamento.

Memória de longo prazo (LTM):

$$
\Delta W_{1}^{L}=-\delta \Delta I_{1} V^{L}
$$

Na qual:

$I_{1}=$ Sinal de treinamento;

$\Delta \mathrm{W}^{\mathrm{L}}=$ diferença a ser acrescentada ou diminuída do peso atual.

Performance:

$I_{1}=\theta_{L}+W_{1}^{L} V^{L}+W_{1}^{R} V^{R}$

Na qual:

$\mathrm{W}^{\mathrm{L}} \mathrm{V}^{\mathrm{L}}$ e $\mathrm{W}^{\mathrm{R}} \mathrm{V}^{\mathrm{R}}=$ Atividade devido a ativação dos mapas espaciais, multiplicado pelos pesos.

\subsection{Considerações Finais}

Redes Neurais tem uma história de mais de 30 anos de sucesso em diversas aplicaçōes. Algumas soluções baseadas em Redes Neurais são capazes de desempenho melhor que modelos matemáticos detalhados, específicos ao problema (Gaudiano et al., 1996).

A maior parte das Redes apresentadas neste Capitulo formam uma familia, compativel entre si, e por isso podem espera-se que suas capacidades possam ser estendidas com relativa facilidade. 


\section{Modelo Proposto}

Neste Capítulo será descrita a organização do sistema de navegação proposto. Inicialmente, são expostas as características e motivações do sistema, que mais adiante serão detalhadas.

\subsection{Introdução e Justificativa}

O sistema de navegação proposto neste trabalho utilizará um mecanismo de mapa cognitivo, inspirado no mapa cognitivo de animais e seres humanos, cujas características foram descritas no Capitulo 4. Justifica-se esta escolha basicamente com dois argumentos. Primeiro, os paradigmas alternativos apresentam certas limitações, examinadas no Capítulo 3, que a utilização de um mapa cognitivo pode aliviar. Em segundo lugar, os sistemas de navegação mais bem sucedidos na natureza, sejam pertencentes a humanos ou outros animais, utilizam-se de uma forma ou de outra deste mecanismo.

Para a implementação do mapa cognitivo, a ferramenta principal a ser utilizada são as Redes Neurais Artificiais, apresentadas no Capítulo 5.

A escolha de Redes Neurais para a implementação é justificada por oferecerem diversas características dificilmente encontradas em outras técnicas. Entre estas características, pode-se destacar a capacidade de aprender por si mesmas através de exemplos, a capacidade de generalização e, no caso das redes ART, a facilidade de operação em tempo real.

Entretanto, o mapa cognitivo por si só não é suficiente para a criação de um sistema de navegação completo. Portanto, módulos especializados são necessários para a realização de outras funções, como por exemplo, a tarefa de evitar obstáculos. 


\subsection{Descrição Detalhada}

A Figura 6.1 apresenta um diagrama de blocos do Sistema Proposto. O sistema será composto de dois níveis de controle: baixo nível, mais ligado ao hardware, e alto nível, responsável pela criação e utilização do mapa cognitivo. Esta é uma abordagem comum na criação de sistemas de navegação. Ela permite que o sistema de alto nível possa ser desenvolvido sem preocupações com as questões de baixo nível, como quantos Volts aplicar a cada roda durante quanto tempo a fim de se obter um determinado movimento.

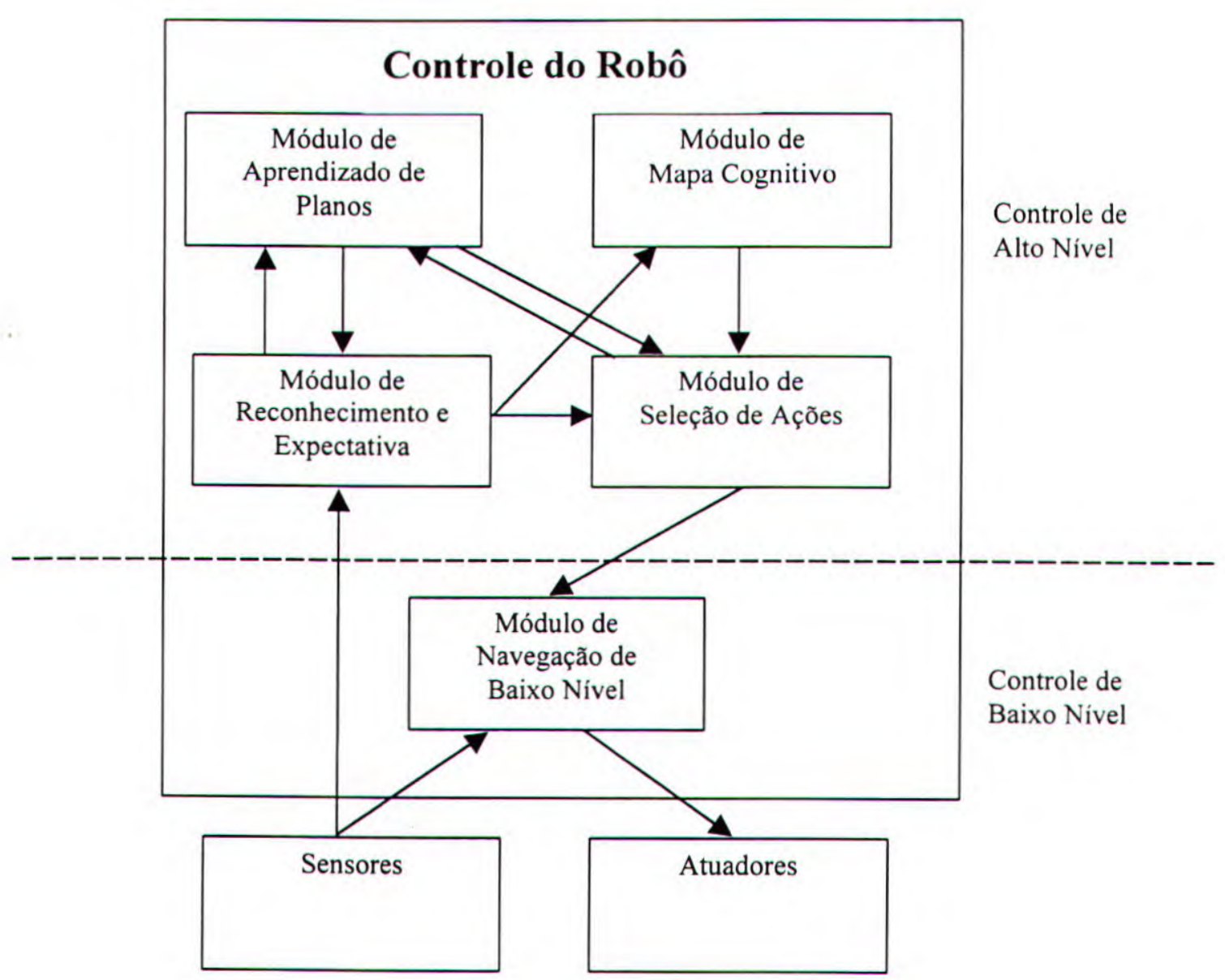

Figura 6.1 - Diagrama de Blocos do Sistema Proposto. 
O sistema de navegação é composto por 5 módulos que interagem entre si. Cada módulo pode ser implementado usando diferentes técnicas, e melhorado de forma independente. Assim, forma-se uma arquitetura genérica de controle para robôs móveis.

O Módulo de Seleção de Açōes, por exemplo, pode ser implementado como um sistema especialista simbólico ou como uma Rede Neural de condicionamento (Grossberg, 1988). Este é o módulo principal, responsável pelo gerenciamento do processo de navegação

Já o Módulo de Navegaçāo de Baixo Nível pode ser implementado através de um sistema reativo baseado em regras, como ocorre em Mataric (1990), ou por um controlador clássico proporcional-integral-derivativo (Zalama et al., 1995). Este módulo é responsável pelas ações de baixo nível e pela tarefa de desvio de obstáculos.

O Módulos de Reconhecimento e Expectativa faz parte do mecanismo de mapa cognitivo, mas oferece entrada também para o Módulo de Aprendizado de Planos, e por isso é representado a parte no diagrama de blocos.

O Módulo de Reconhecimento é implementado como uma Rede Neural do tipo ART1 (Seção 5.3). Sua função é reconhecer os lugares pelos quais já passou antes, e aprender lugares novos, pelos quais ainda não passou.

O Módulo de Mapa Cognitivo pode ser implementado como uma Rede Neural do tipo VAM (Seção 5.5) para situações muito simples. Para tratar com funções mais complexas, utilizou-se posteriormente uma Rede Neural do tipo MLP (Seção 5.4). A função deste módulo é associar os lugares que o Módulo de Reconhecimento aprende, com a localização fisica destes lugares, de modo que posteriormente, dado o lugar a ser alcançado, o sistema tenha a informação de onde este lugar esta localizado no ambiente.

O Módulo de Aprendizado de Planos pode ser implementado como um conjunto de listas encadeadas. O conteúdo destas listas compreende os diversos lugares pelos quais o robô passou ao ir de um lugar para outro. Como alternativa, um tipo de Rede Neural que pode ser usada para implementar este Módulo, é a rede de aprendizado serial (Grossberg, 1982). 


\subsubsection{Módulo de Navegação de Baixo Nivel}

O módulo de navegação de baixo nível é responsável pela atuação do robô quando o alvo está localizado dentro da área de alcance de seus sensores. Ele é chamado de baixo nível porque é o que está mais diretamente ligado ao hardware, e não tem acesso a conhecimentos de alto nível, como mapas do ambiente.

A função deste módulo em um robô móvel com rodas é selecionar a velocidade angular de cada uma das rodas de direção.

A utilização de um módulo de controle de baixo nível é vantajosa porque ele é capaz de tratar questões como compensação em tempo real de descalibrações inesperadas, como mudanças na estrutura do robô, mudanças no ambiente (como alvos móveis) e chão escorregadio. Por isso, ele é capaz de atuar em ambientes desconhecidos e em pequenas distâncias.

Assim, os módulos de alto nível ficam livres para tratar de questões como aprender o ambiente, tomar decisões de exploração e planejar rotas. Especificamente, uma rota será formada por um conjunto de lugares que o robô deve atingir. Estes lugares estarão sempre dentro do alcance sensorial do robô, de modo que o módulo de baixo nível possa executar a tarefa.

Um modelo possível para a implementação do Módulo de Navegação de Baixo Nível, é a Rede Controladora de Robô Móvel NETMORC (do inglês, Network Mobile Robot Controller). Este modelo foi criado por Zalama e Gaudiano, e apresentou, segundo seus autores, desempenho um pouco melhor do que um controlador PID (proporcional-integralderivativo), baseado em soluções matemáticas (Gaudiano et al., 1994).

Este modelo é implementado por uma Rede Neural não supervisionada, ou seja, não requer um professor ou exemplos do comportamento requerido. Ao invés disso, ele aprende autonomamente. Nenhum modelo do robô, nem do ambiente é exigido. O modelo NETMORC e seus módulos são apresentados na Figura 6.2.

O modelo NETMORC utiliza-se de dois outros modelos de Rede Neural: VAM (Gaudiano \& Grossberg, 1991), já apresentado na Seção 5.5, e DIRECT (Bullock et al., 1993). 


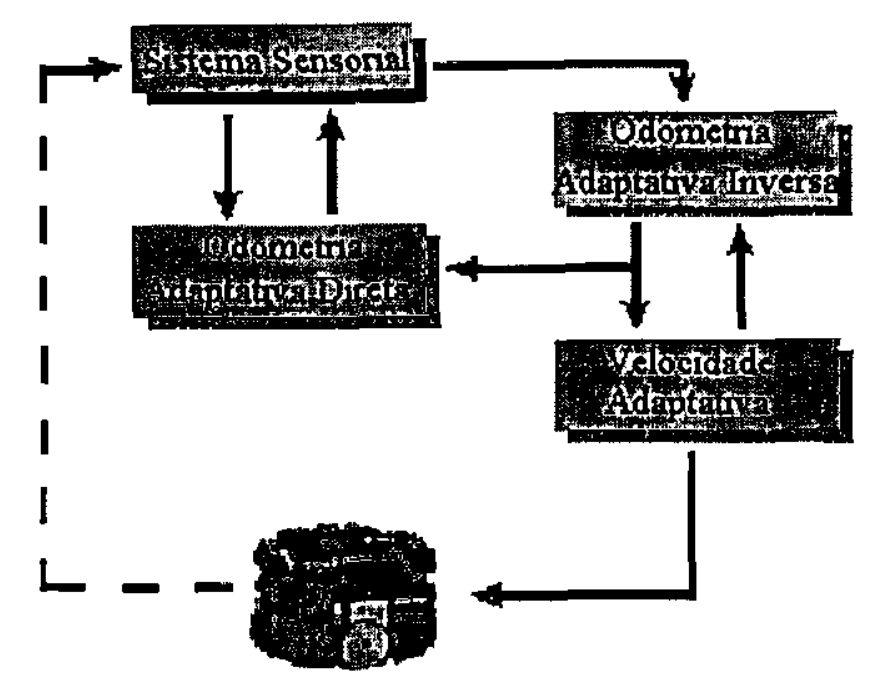

Figura 6.2 - Diagrama mostrando os módulos do modelo NETMORC.

O modelo DIRECT mostra como é possível a utilização de informaçães sobre os próprios comandos de movimentação de um braço para estimar sua posição final. Isto permite que se estime, com alguma precisão, onde o braço está depois de um comando de movimentação, mesmo que uma informação sensorial mais precisa, como por exemplo a visão do braço, não esteja disponível. Quando este princípio é aplicado ao NETMORC, o robô móvel é capaz de estimar sua posição, mesmo que esteja no momento sem informação explícita dos sensores de ultra - som. Com isso, o sistema se torna mais robusto e resistente a falhas.

O modelo NETMORC é capaz de guiar o robó para o alvo se o alvo estiver dentro do alcance dos sensores. Também é capaz de desviar de obstáculos móveis, como por exemplo, pessoas e animais domésticos. Assim, o modelo NETMORC é capaz de preencher os seguintes requisitos de um sistema de navegação, conforme proposto na Seção 2.1:

1. evitar colisões;

3. operar em um ambiente dinâmico;

4. desviar de obstáculos móveis;

6. ser capaz de atuar em um ambiente previamente desconhecido. 


\subsubsection{Mapeamento do Ambiente}

Quando o alcance dos sensores é pequeno e o alvo está além deste alcance, como ocorre quando existem obstáculos obstruindo a vista do alvo, entra em ação o Sistema de Controle de Alto Nível, que inclui o mapa cognitivo.

O robô inicialmente deverá buscar marcos já vistos previamente. Marcos são lugares no ambiente que podem ser distinguíveis uns dos outros, salientes e relativamente fixos, como por exemplo; paredes, escadas e portas.

Estando em um destes marcos, o robô poderá lembrar a localização dos outros objetos do ambiente. Ele sabe, por exemplo, que do lado oposto ao da porta, existe uma escada. Este conhecimento espacial é representado de forma alocêntrica, isto é, relaciona à posição de cada objeto em relação aos outros, ao invés de relacionar a posição dos objetos em relação à posição do observador (representação egocêntrica). Por isso, é mais fácil relacionar os objetos entre si quando se está próximo de um marco.

Para implementar a operação de mapeamento do ambiente, é efetuado um trabalho conjunto entre o Módulo de Reconhecimento e Expectativa e o Módulo de Mapa Cognitivo.

No Módulo de Reconhecimento e Expectativa, para cada célula representando um marco haverá um conjunto representando as características encontradas naquele marco pelos sensores. Assim, o Módulo pode reconhecer os lugares através de comparação, nas próximas vezes que o robô passar por eles.

Ao mesmo tempo, o Módulo de Mapa Cognitivo determina os locais onde os marcos foram registrados. As duas informações (descrição e localização) são então associadas, de modo a estarem disponíveis quando necessário.

$O$ processo de mapeamento do ambiente, portanto, preenche os seguinte requisitos propostos na Seção 2.1:

5. mapear e levar em consideração os espaços abertos;

6. ser capaz de atuar em um ambiente previamente desconhecido. 


\subsubsection{Auto - Localização}

Para se localizar no ambiente, e assim definir o ponto inicial da jornada a fim de iniciar o planejamento, o robô deverá seguir até o marco mais próximo, seja ele do tipo que for. Por exemplo, qualquer muro poderá servir.

Ao se deparar com este marco, duas situações podem acontecer:

I) O marco é tão único e distintivo que o robô já sabe qual o lugar que está ocupando. Por exemplo, uma mesa com formato particular;

2) O marco é um tipo comum, encontrado em diversas partes do ambiente. Por exemplo, uma parede.

Em ambos os casos, o sistema toma um lugar determinado como hipótese e se lembra das outras coisas que deveriam estar ao redor, se a hipótese estiver correta. Se, ao andar pelo ambiente, os objetos estão nos lugares esperados pelo sistema, a hipótese estava correta e nenhuma ação precisa ser tomada. Porém, se ao andar pelo ambiente os objetos esperados não são encontrados, a hipótese estava errada e outra é recuperada. Quando nenhuma hipótese plausível puder ser recuperada e verificada é sinal que o ambiente é novo e portanto deve ser aprendido. Neste caso, o sistema entra no estado de aprendizado e vai mapeando o ambiente da forma descrita no Item 6.2.2. (Mapeamento do Ambiente).

No caso do robô se perder, o mesmo procedimento é invocado. A única diferença é que as hipóteses a serem previstas primeiro são aqueles lugares mais próximos de onde o robô se perdeu. Para se achar a primeira vez, na ausência de marcos distintivos, o processo pode demorar mais.

Para as operações de escolha, verificação e mudança de hipótese, assim como a troca do modo de exploração para o modo de aprendizado, a rede mais indicada é uma rede ART, descrita na Seção 5.3.

O processo de auto - localização garante que se o ambiente foi modificado, isto é, o ambiente é dinâmico, sua nova configuração será aprendida e por isso preenche o requisito proposto na Seção 2.1:

\section{3. operar em um ambiente dinâmico;}




\subsubsection{Navegação}

Sabendo onde está o alvo, o robô poderá determinar uma trajetória em direção a ele. Neste momento, o problema a ser resolvido é o de navegação (como ir de um lugar a outro). Para isto o robô tem um conjunto de alternativas.

Se o alvo estiver em uma posição próxima, o Módulo de Navegação de Baixo Nível pode ser invocado, gerando um comando (vetor direcional) para se locomover até ele, inclusive desviando-se de possíveis obstáculos em seu caminho. Este é o caso trivial. É através do vetor direcional que as distâncias entre os objetos serão registradas e armazenadas.

A medida que o robô vai andando em seu ambiente, os vetores direcionais serão gerados em uma variedade de direções e distâncias. Os sensores revelaram quando o robô atingiu o alvo. Usando informações geradas pelos codificadores de roda, o robô sabe o quanto andou.

Estas duas informações (direção e centímetros rodados) serão associadas, o que permitirá, no futuro, que o robô possa se locomover com precisão, mesmo com falha em alguns sensores. Mais importante que isso, de posse desta informação métrica, o robô poderá aumentar sua velocidade de navegação com segurança. Outra vantagem desta informação métrica ficar mais precisa é que o robô poderá utilizá-la para distinguir entre partes do ambiente que de outra forma seriam consideradas iguais.

A segunda forma que o robô dispõe para navegar é lembrar um plano que o leve da posição atual até o alvo. A responsabilidade pela criação e manutenção destes planos cabe ao Módulo de Aprendizado de Planos. Um plano é composto de um conjunto de lugares ou alvos intermediários. Se a ação de seguir um plano for escolhida e, se os alvos intermediários contidos no plano ficarem dentro da área dos sensores, o mecanismo de controle de baixo nível é utilizado. Caso contrário, para que o plano possa ser realizado, será necessário usar o mecanismo de Mapa Cognitivo.

A terceira forma de realizar a navegação é fazer uma "caminhada mental". Esta modalidade é a que mais se aproxima das abordagens tradicionais, sendo equivalente à busca em grafo.

O robô poderá iniciar do lugar em que se encontra e lembrar dos lugares que estão nos arredores. Depois, ao lembrar do lugar adjacente, outro lugar ligado a este é também lembrado, e assim sucessivamente, até que uma sequiência de lugares seja lembrada, até o alvo 
ser atingido. Isto seria equivalente ao método de busca em grafo forward chaining, que vai de um nó inicial para o nó final através de nós intermediários.

Alternativamente, o robô poderá pensar no alvo e lembrar de lugares adjacentes a ele. Estes Iugares adjacentes evocam a lembrança de outros lugares ligados a eles, e assim sucessivamente até que o lugar em que o robô está localizado seja lembrado. Este método seria equivalente a uma estratégia de busca em grafo conhecida como backward chaining, que vai de um nó final para o nó inicial através de nós intermediários.

Quando o robô realizar as operações de caminhada mental, tanto para frente quanto para trás, ao se atingir mentalmente o alvo, pode-se concluir que a rota escolhida foi boa, e isto é recompensado. Por outro lado, se a rota desenvolvida mentalmente não levar ao alvo, ela receberá uma espécie de punição.

Sempre que o robô seguir uma trajetória, os lugares pelos quais ele passa são lembrados e coletados, formando um plano. Numa próxima ocasião, quando o robô necessitar novamente atingir o mesmo lugar, este plano será uma alternativa disponível para que ele possa navegar.

O procedimento de navegação não tem como objetivo a geração de planos ótimos, mesmo porque em um ambiente dinâmico, do qual só se tem disponível informação local, é impossivel garantir um plano ótimo. Porém, este procedimento de navegação garante que as possibilidades sejam exploradas, e as possibilidades exploradas primeiro são aquelas que tem maior probabilidade de levarem o robó ao alvo de forma mais rápida. Assim, o procedimento de navegação preenche o seguinte requisito, proposto na Seção 2.1:

\section{2. alcançar o objetivo rapidamente;}




\subsection{Considerações Finais}

As Redes Neurais auto organizáveis inspiradas biologicamente se encaixam bem nos requisitos apresentados na implementação do mapa cognitivo. Assim, pode-se responder adequadamente às demandas e requisitos apresentados no Capítulo 2 .

Pesquisas anteriores chegaram a implementar pequenas partes com sucesso, como 0 planejamento baseado em "caminhada mental", que foi implementado no trabalho de Schmajuk e Thieme (Schmajuk \& Thieme, 1992). Este trabalho, porém, utiliza somente informação topológica e exige que os marcos intermediários sejam conhecidos previamente pelo robô. Exige ainda que, estando em um determinado marco, $\mathrm{m}_{\mathrm{i}}$, o robô sempre possa enxergar o próximo marco, $\mathrm{m}_{\mathrm{i}+1}$. No presente trabalho, estas restrições não se aplicam porque o mapa cognitivo possui informações métricas, além de informações topológicas.

Estes sucessos anteriores encorajam a continuidade da pesquisa, indicando fortes possibilidades de sucesso com a arquitetura proposta.

Finalmente, a arquitetura proposta para o sistema de navegação tem a possibilidade de preencher todos os requisitos propostos na Seção 2.1:

1. evitar colisões;

2. alcançar o objetivo rapidamente;

3. operar em um ambiente dinâmico;

4. desviar de obstáculos móveis;

5. mapear e levar em consideração os espaços abertos;

6. ser capaz de atuar em um ambiente previamente desconhecido. 


\section{Projeto do Mapa Cognitivo}

Nesta dissertação foi desenvolvido um mecanismo de mapa cognitivo, com o objetivo de permitir a um sistema de navegação para robôs móveis mapear seu ambiente e fornecer subsídios para que este sistema possa planejar uma rota entre o lugar de origem e o lugar alvo. Neste Capítulo, o mecanismo de mapa cognitivo criado como resultado da pesquisa apresentada nesta dissertação será descrito.

\section{1. $O$ uso de mapas para expandir as capacidades de navegação}

Dentro da Seção 6.2, no Item 6.2.1, foi discutido como um sistema de navegação de baixo nivel é capaz de controlar o robô e chegar a um alvo que esteja dentro do alcance de seus sensores.

Para os casos em que o alvo está além do alcance sensorial, ou obstruído, como por exemplo, atrás de uma parede ou porta, o uso de mapas para navegação é a opção mais utilizada.

Os mapas podem ser classificados como: métricos, se registram as posições ocupadas pelos marcos no ambiente, ou topológicos, se registram apenas quais são os marcos existentes e informação sobre sua ordem e relacionamento.

Também pode-se classificar um mapa como: global, se a posição dos marcos é registrada em relação a um ponto inicial, ou local, se diferentes pontos iniciais são utilizados para o registro da posição dos marcos.

Os próximos itens discutem as diferenças entre estes tipos de mapas em maiores detalhes. 


\subsubsection{Mapas Métricos $\times$ Mapas Topológicos}

O uso de mapas métricos globais exige que os sensores de mapeamento (como por exemplo, os encoders das rodas) estejam sempre calibrados perfeitamente. Mas isso é praticamente impossível, o que leva muitos pesquisadores a adotarem métodos estatísticos para tratarem as incertezas associadas.

Uma alternativa que vem sendo cada vez mais considerada em pesquisas de navegação é a utilização de mapas topológicos. Estes mapas, em contraste com os mapas métricos globais, não tem um sistema de coordenadas global ao qual o robô precisa se alinhar.

Ao invés de coordenadas métricas, os mapas topológicos são construídos geralmente sob a forma de grafos. Estes mapas consistem nos marcos encontrados no ambiente pelo robô, conectados entre si. Os marcos são representados como nós do grafo e as conexões entre os marcos são os arcos. Desta forma, é possível utilizar algoritmos de busca em grafos como o A* (Rich \& Knight, 93) para percorrer estes grafos e encontrar um caminho nele.

Se os marcos mais próximos uns dos outros puderem ser vistos da posição onde o robô se encontra, então, de posse de uma sequência de nós (os marcos), é possível para o robô navegar em seu ambiente, mesmo sem dispor de um mapa métrico apurado. Este esquema foi utilizado por Mataric (1990), que o implementou através de um grafo, e também na pesquisa de Schmajuk e Thieme (1993), que o implementaram através de Redes Neurais.

Na implementação de Schmajuk \& Thieme (1993), uma Rede Neural aprende, em uma primeira fase, quais são os marcos mais próximos daquele no qual o robô está localizado. Posteriormente, a rede recupera os marcos pelos quais o robô deverá passar para se locomover de um ponto inicial a um ponto final.

Uma solução intermediária, na qual tanto o componente topológico quanto o componente métrico são capturados, foi proposta por Kuipers (Ver Seção 4.4). Nesses modelos, os marcos são armazenados também com os ângulos e distâncias entre eles.

Esta solução combinada permite um melhor planejamento da movimentação, podendo inclusive permitir ao robô alcançar maiores velocidades de navegação. 


\subsubsection{Mapas Globais $\times$ Mapas Locais}

A fim de se formar um mapa do ambiente, é necessário posicionar os objetos em relação a alguma coisa.

Esta alguma coisa pode ser um sistema de coordenadas absolutas ou globais (ex.: um sistema de coordenadas cartesianas, em que a origem seja o centro da sala ou o canto de uma parede).

Outra possibilidade é posicionar os objetos em um sistema de coordenadas relativas ou locais, como por exemplo, armazenar a posição dos objetos em relação uns aos outros.

Uma variação desta idéia é considerar que o robô sempre estará vendo o ambiente estacionado em um determinado ponto, e relacionar a posição dos objetos em relação a este ponto fixo de observação.

\subsubsection{Mapa Local + Mapa Métrico $=$ Mapa Cognitivo}

A utilização de um mapa local está de acordo com a sugestão de Kuipers (Seção 4.4) de que o mapa cognitivo na verdade é um atlas cognitivo, composto de diversos mapas locais, com um sistema de coordenadas próprio.

A implementação do mapa cognitivo através de mapas locais também está de acordo com a idéia de O'Keefe e Nadel (1978), de que o mapa cognitivo é instanciado em uma única estrutura cerebral (o hipocampo), de modo que esta mesma estrutura deve suportar a instância de diversos locais.

\subsection{Mapeamento local com informação topológica e métrica}

Para que um ambiente possa ser mapeado de forma local, não é suficiente ter informaçð̃es egocêntricas, apenas do ângulo e da distância entre o robô e os objetos. Mas estas são as informações obtidas através dos sensores de ultra-som, por exemplo.

Informações egocêntricas são insuficientes porque um mesmo objeto pode ser visto de inúmeros ângulos e distâncias e, da mesma forma, um mesmo ângulo e distância pode levar a percepção de objetos diferentes.

Por exemplo, na Figura 7.1, considere que, na sua posição original, o robô está em C1. A posição $\mathrm{C} 2$ estará localizada a $45^{\circ}$ e $1 \mathrm{~m}$ de distância. Por outro lado, se o robô estiver localizado originalmente em $\mathrm{C} 3$, a posição $\mathrm{C} 2$ estará localizada a $0^{\circ}$ e $3 \mathrm{~m}$ do robô. Portanto, o mesmo objeto (C2) pode ser representado por diferentes combinações ângulo/distância. 
Já estando na posição $\mathrm{C} 4, \mathrm{o}$ ângulo $0^{\circ} \mathrm{e} 3 \mathrm{~m}$ leva à percepção da posição $\mathrm{Cl}$, enquanto que o ângulo $45^{\circ}$ e $1 \mathrm{~m}$ leva à percepção da posição C3. Assim, o mesmo ângulo/distância $\left(0^{\circ}\right.$ e $3 \mathrm{~m}$ ) pode levar à percepção de objetos diferentes. Ou seja, pode-se concluir que tudo depende de onde o observador está situado.

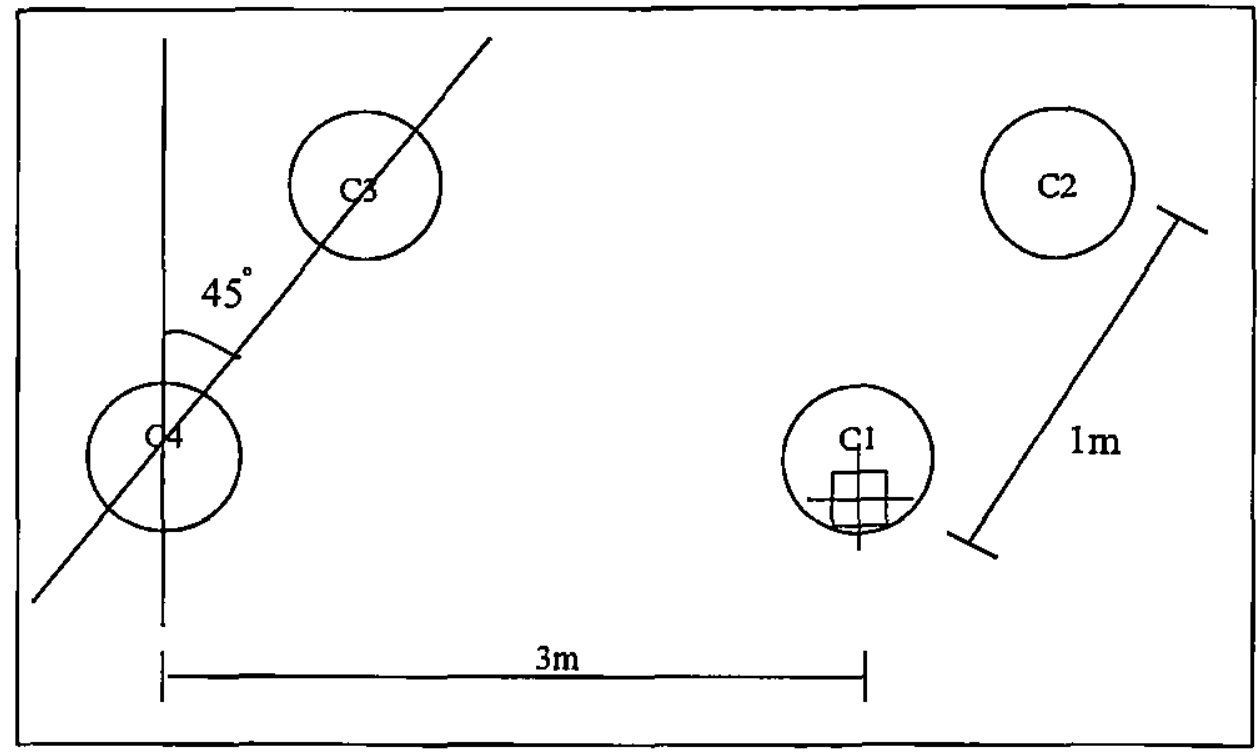

Figura 7.1 - Um ambiente formado por 4 marcos.

$\mathrm{O}$ ângulo e a distância entre $\mathrm{C} 3 \mathrm{e} \mathrm{C} 2$ são equivalentes àqueles entre $\mathrm{C} 4 \mathrm{e} \mathrm{C} 1$. Também o ângulo e distância entre $\mathrm{C} 1$ e C2 são equivalentes àquele entre $\mathrm{C} 4$ e C3.

A Figura 7.2 mostra que se o observador tem sua atenção atraída para um determinado alvo fixo, um neurônio ou população neural que representa este alvo deverá ser ativada, não importando se o observador se movimenta ou permanece parado. Uma Rede Neural cujos neurónios representam alvos possíveis é chamada de Mapa de Posições Alvo (Grosberg \& , 1986), ou TPM (do inglês Target Position Map).

No exemplo da Figura 7.2, quando observador está com sua atenção fixada no retângulo vermelho, ele pode se mover para o ponto $A, B$ ou $C$. Conforme mostrado nas partes (a), (b) e (c) desta figura, uma única posição no TPM (um neurônio, por exemplo) permanece ativada para estes três movimentos.

Da mesma forma, se a atenção do observador estiver no círculo azul, ele pode se mover para o ponto A, B ou C, e conforme mostrado nas partes (d), (e) e (f) da Figura 7.2, uma mesma posição no TPM (diferente da anterior) permanece ativada. 
(a)
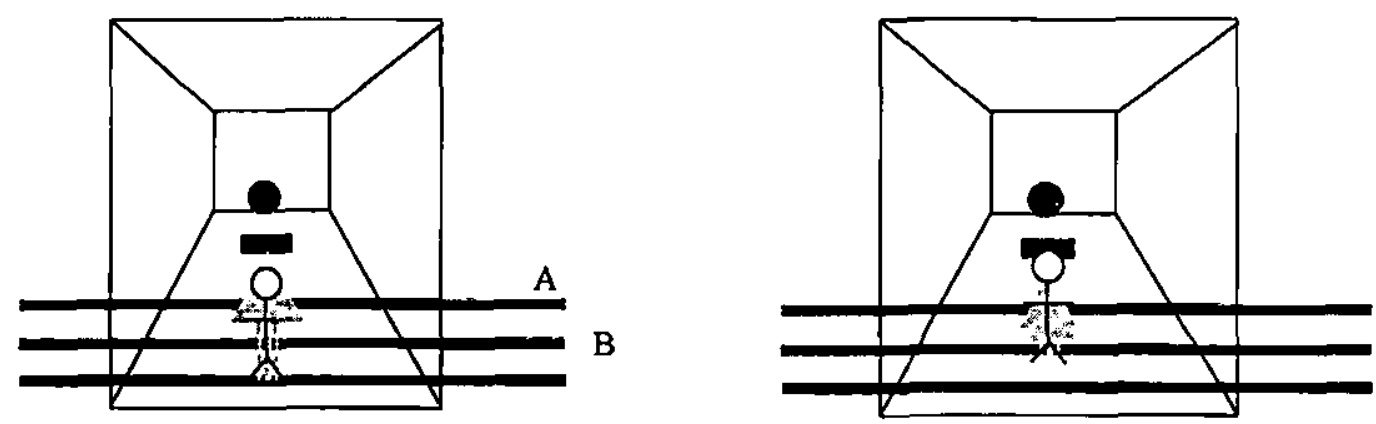

(b)

\begin{tabular}{|c|c|}
\hline Ouando está em C: & $\begin{array}{c}\text { Quando está em B: } \\
\text { Distância: } 3-\mathrm{R} \\
\text { Direção: } 0^{\circ} \\
\text { Direçãa: } 0^{\circ}\end{array}$ \\
TPM: $\Theta$ & TPM: $⿴ 囗 十$ \\
Foco de Atenção: RETÂNGULO & Foco de Atenção: RETÂNGULO \\
\hline
\end{tabular}

(c)
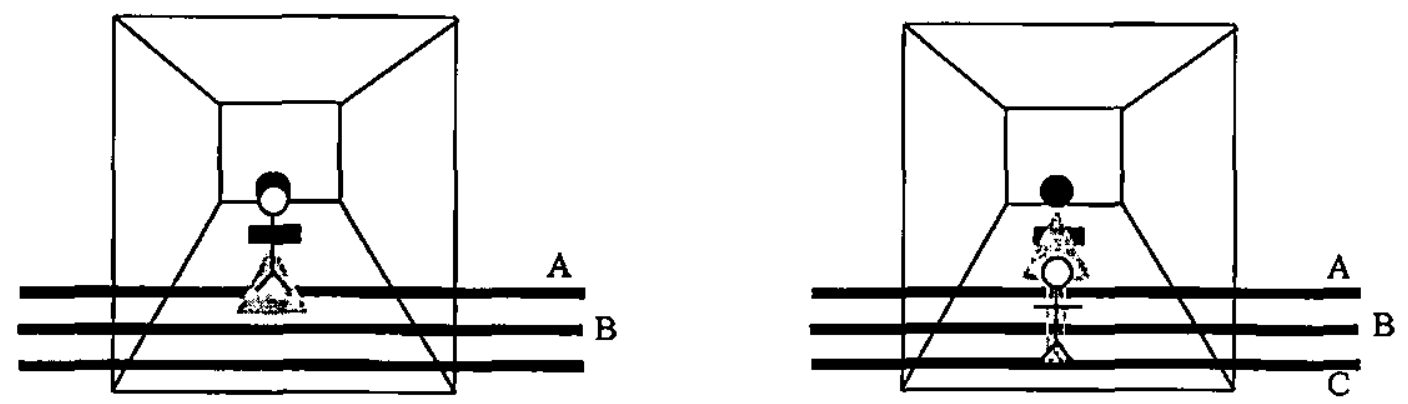

(d)

\section{Quando está em A: \\ Distância: 1-R \\ Direção: $0^{\circ}$ \\ TPM:}

Foco de Atenção: RETÂNGULO
Quando está em C:

Distância: 4-R

Direção: $0^{\circ}$

TPM:

EP

Foco de Atenção: CÍRCULO

Figura 7.2 - Um observador e vários objetos. 
(e)

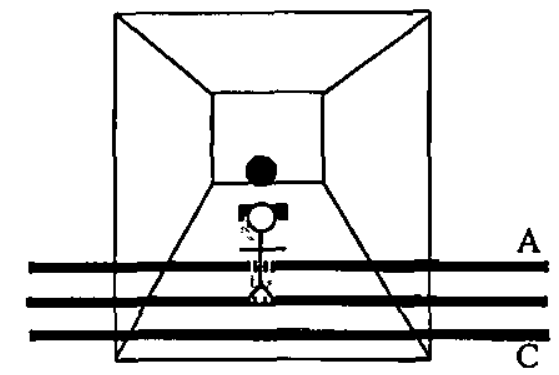

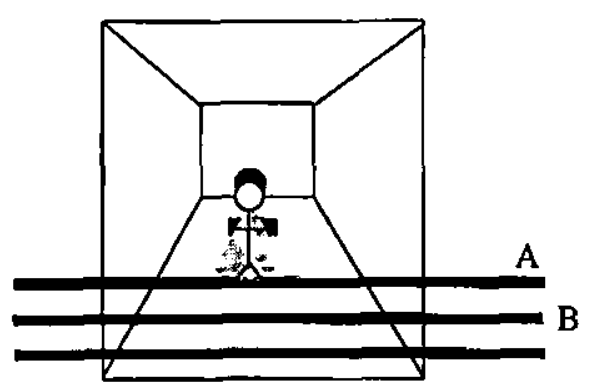

Quando está em B:

Distância: 2-R

Direção: $0^{\circ}$

TPM:

Foco de Atenção: CÍRCULO
Distância: 3-R

Direção: $0^{\circ}$

TPM:

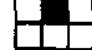

Foco de Atenção: CÍRCULO
Figura 7.2 (cont.) - Um observador e vários objetos.

O observador está em diferentes pontos (linhas $\mathrm{A}, \mathrm{B}$ e C) e olha para diferentes objetos(círculo e retângulo). Entretanto, em muitas combinações, o ângulo e a distância são as mesmas. Para diferenciar, é necessário alguma informação sobre em que ponto o observador está situado.

Nota-se novamente entretanto, que apenas informações egocêntricas (ângulo e distância), não são suficientes. Na Figura 7.2, a informação egocêntrica nos itens (a) e (e), e nos itens (b) e (f) são iguais, mas a posição ativada no TPM é diferente. Deve haver, portanto, outra informação capaz de realizar uma diferenciação entre estes casos. Qual será esta informação?

Para encontrar a informação que falta, nota-se que as observações acima apontam uma evidência para suportar a citação de Yeap (1988), p. 309:

"Kaplan[34] afirmou que saber onde se está é de importância primária para nosso comportamento adaptativo neste mundo perigoso e imprevisivel, e esta informação deve estar prontamente disponivel no mapa cognitivo".

Esta informação, saber onde se está, é exatamente a informação que falta. No exemplo da Figura 7.2, a diferença entre as situações apresentadas é em qual objeto a atenção está voltada. Este objeto define onde está o observador. Este objeto é exatamente o marco, elemento fundamental mencionado nas várias teorias cognitivas apresentadas no Capítulo 4. 


\subsection{Mapa Cognitivo Invariante}

O mapa cognitivo descrito na última seção é invariante. Isto significa que os parâmetros que definem qual o neurônio no TPM deve ser ativado podem mudar, mas o neurônio ativado permanece o mesmo. Quais são os parâmetros variáveis que definem qual o neurônio a ser ativado no TPM?

Iniciando com o caso mais simples do robô andando em uma dimensão, estes parâmetros são: distância do robô ao alvo e distância do robô ao marco. Estes são parâmetros provenientes do sistema sensorial do robô.

A soma destas duas distâncias é invariante. Quando uma aumenta, a outra diminui. Por isso, a soma destes parâmetros pode ativar um determinado neurônio no TPM de forma invariante. Desta forma, o neurônio representa a distância entre o marco e o alvo, sem levar em conta a localização do robô, que pode variar a vontade.

No caso real do robô em duas dimensões, é necessário levar em conta os ângulos que o robô forma em relação ao marco e ao alvo. Variando-se o ângulo/distância do robô ao marco e do robô ao alvo, ainda deverá ser possível a ativação invariante de um único neurônio no TPM. Novamente, este neurônio representa a distância entre o marco e o alvo.

Para a implementação de um mapa cognitivo invariante, tem-se assim os parâmetros de entrada e de saída.

Como entrada, tem-se o ângulo e a distância do robô em relação ao marco, e do robô em relação ao alvo. Estes parâmetros variam de acordo com a movimentação do robô no ambiente.

Como saída, tem-se o neurônio ativado no TPM, que representa a distância entre o marco e o alvo, distância esta que é invariante.

Um mapa cognitivo assim projetado é capaz de fornecer a informação métrica de um determinado ambiente. Para complementar sua atividade, ainda é necessário um outro módulo, capaz de associar descrições de lugares a cada uma das localizações ativadas no TPM.

Na próxima seção um mecanismo deste tipo é considerado. No Capítulo 8 são apresentados experimentos mostrando casos em uma e em duas dimensões. 


\subsection{Instância de Ambientes no Hipocampo}

Defende-se (O’Keefe \& Nadel, 1978) que a função do hipocampo nos ratos é prover um mapa cognitivo, de modo que o rato possa se localizar e encontrar caminhos no ambiente. Segundo O'Keefe (1994), no hipocampo dos ratos, um mesmo conjunto de células deve suportar a instanciação de inúmeros ambientes.

Como um mesmo conjunto fixo de células pode representar vários ambientes, ou seja, apresentar diversos padrões de atividade, um para cada ambiente? Basta que estas células fixas recebam os padrões de atividade de outras células. O padrão de ativação do hipocampo dependerá de quais são estas outras células ativadas. Este padrão de atividade, proveniente de células estrangeiras para o hipocampo passa por um filtro adaptativo (Grossberg, 1982).

Como são armazenados estes diferentes padrões que representam os lugares? Serão armazenados quando o hipocampo começar a registrar os padrões do ambiente. Este registro se dá nas conexões entre o hipocampo e a população de células estrangeiras. Ver Figura 7.3.

Suponha que um ambiente é representado por um dado conjunto de ativações e estas ativações são armazenadas diretamente nas conexões com as células estrangeiras. Então, esta representação do ambiente somente será útil quando o rato estiver exatamente no lugar original, de onde a "fotografia" do ambiente foi tirada, ou seja, os padrões foram armazenados. Isto é um mapa baseado em coordenadas egocêntricas.

Sabe-se que os ratos são capazes de se locomover com facilidade em um ambiente já visto, mesmo se forem colocados em locais iniciais diferentes. Isso acontece sem que o rato tenha que conhecer todos os possíveis locais iniciais (Schmajuk, 1997).

Assim, pode-se concluir que o hipocampo deve ser um mapa invariante, funcionando conforme explicado na seção anterior. Sendo um mapa invariante, poucas experiências com um ambiente qualificariam o rato a se locomover nele com competência, mesmo sem ter estado em todos os possíveis locais. 

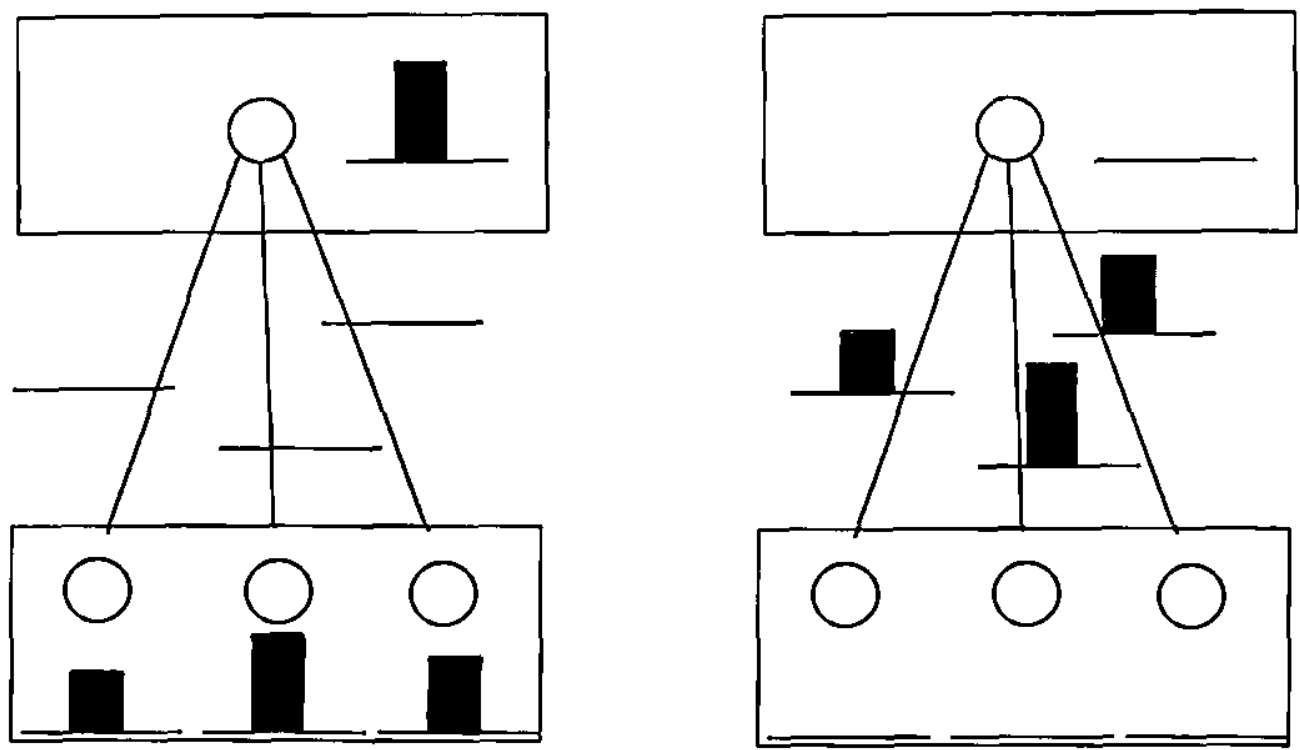

Figura 7.3 - Aprendizado num "hipocampo" simulado.

(a) O padrão de ativação do hipocampo sendo aprendido. Os objetos do ambiente estão ativos, bem como as células que representam suas posições. (b) $O$ padrão de ativação do hipocampo, depois de aprendido, fica armazenado nas conexões.

O mapa invariante é composto de diversas células, uma representando cada espaço possível de ser atingido pelo robô, ou seja, cada espaço que faz parte do ambiente.

Este mapa é único e finito. Porém, ele tem que ser útil para representar inúmeros ambientes. Como representar vários ambientes (um por vez, é claro) usando a mesma população de células?

De alguma forma, apenas as células que fazem parte do ambiente, ou seja, que representam objetos presentes no mesmo ambiente, devem ser acionadas a cada vez. Uma memória auto-associativa constrói um padrão completo a partir de alguns de seus componentes.

Exatamente através de uma memória auto-associativa é possivel preencher os requisitos necessários para representar vários ambientes em uma mesma população neural.

Ao se utilizar de células que não fazem parte do TPM, pode-se associar vários ambientes diferentes, um por vez, com uma única população de células do TPM. Ver Figura 7.4 . 


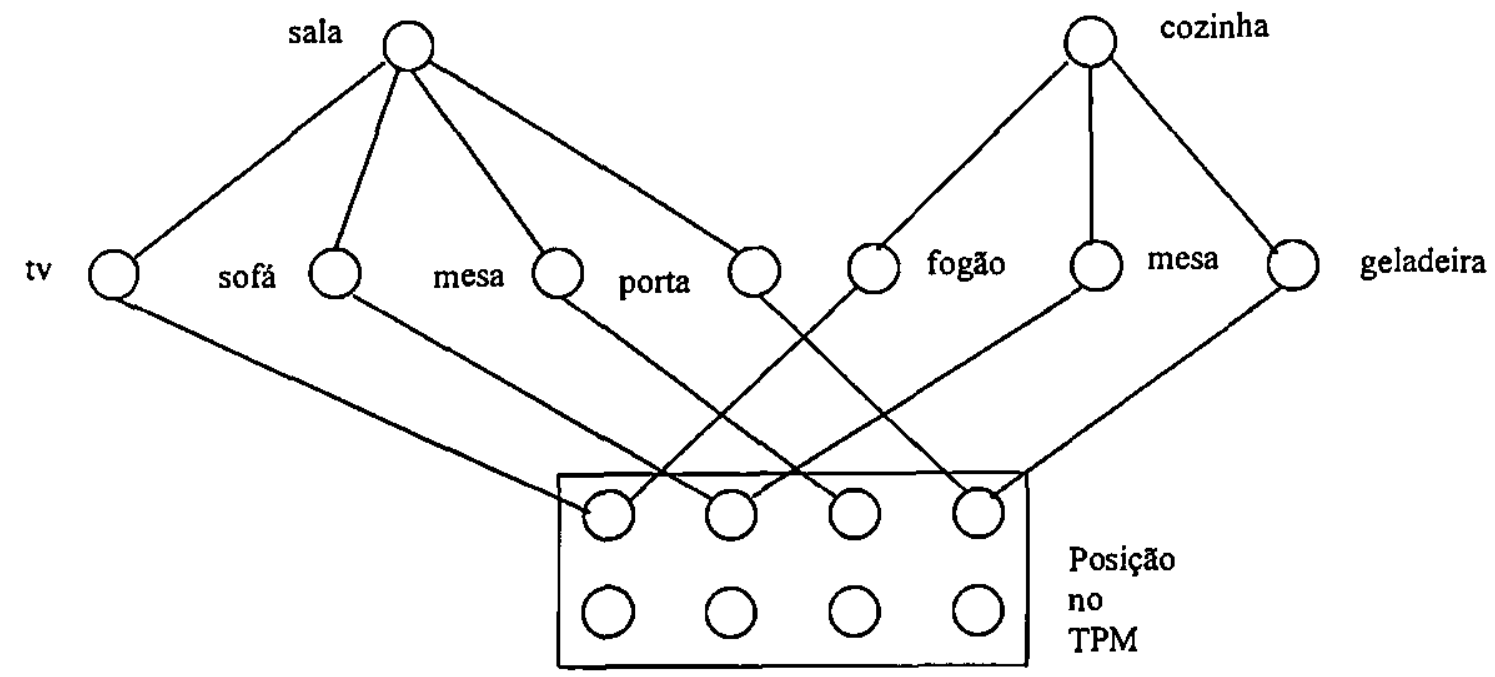

Figura 7.4 - Dois ambientes representados por um mesmo TPM.

Através de uma memória auto-associativa, quando partes do ambiente estiverem ativadas, o ambiente todo será ativado e o TPM será ocupado por ele, enquanto que a ativação do outro ambiente é suprimida.

$\mathrm{Na}$ Figura 7.4, as células externas ao TPM são células que reconhecem as características de um lugar e elas são associadas às células ativadas no TPM. Elas fazem parte de um grupo, por exemplo, a sala ou a cozinha de uma casa, e são mutuamente exclusivas, ou seja, ambas não podem estar ativas ao mesmo tempo, porque isso causaria uma inconsistência no mecanismo de mapa cognitivo.

Então, para evitar estas possíveis inconsistências, pode ser empregado um mecanismo de expectativa. Desta forma, a informação proveniente dos sensores pode ser ambígua. Ao utilizar o mecanismo de expectativa, é possível saber exatamente qual o ambiente atual.

Uma Rede Neural que oferece mecanismo de expectativa e de reconhecimento é a rede ART1, apresentada na Seção 5.3. 


\subsection{Consideraçōes Finais}

Para a implementação do mapa cognitivo, há necessidade de dois módulos fortemente acoplados. Estes dois módulos correspondem grosseiramente aos subsistemas "O que" $\mathrm{e}$ "Onde", que se postula existirem no cérebro humano.

O sub-sistema "Onde" é responsável por determinar os locais onde os objetos são vistos pela pessoa. $O$ sub-sistema " $O$ que" complementa o primeiro, reconhecendo os objetos observados. Da junção destes sistema, nasce o mapa cognitivo.

No próximo Capítulo, serão apresentados experimentos mostrando como tal mecanismo de mapa cognitivo foi construído através de duas redes neurais, cada uma desempenhando um dos papeis descritos neste Capitulo. 


\section{Experimentos Realizados}

Para a implementação do sistema proposto, utilizou-se uma abordagem incremental. A idéia original era obter um mapa cognitivo simples, que funcionasse para um robô operando em uma dimensão. Apenas a distância entre o robô, o alvo e o marco seria considerada, ignorando-se no primeiro momento os ângulos formados.

A primeira parte foi completada com êxito. Foram utilizadas as redes VAM [Gaudiano \& Grossberg, 1991] e ARTl [Grossberg, 1988]. Infelizmente, ao tentar expandir a rede VAM para tratar do caso mais geral, do robô em duas dimensões, constatou-se que a mesma não conseguia lidar com o problema.

Como resultado, abandonou-se a rede VAM. Em seu lugar foi empregada uma rede MLP, treinada com o algoritmo Back Propagation. Esta rede cumpriu a tarefa, mas com certas desvantagens.

Neste Capítulo, serão apresentados os experimentos realizados durante a pesquisa, mostrando o andamento do trabalho desde os primeiros protótipos até sua implementação final.

\subsection{O Robô em Uma Dimensāo}

Decidiu-se utilizar o modelo de Rede Neural VAM por este apresentar aprendizado em tempo real e ser on-line. Este modelo foi utilizado com sucesso em aplicaçōes de controle de motores de câmera [Srinivasa, N., Sharma, 1998], e é a base do modelo NETMORC [Gaudiano et al., 1994], já apresentado.

O experimento 1, mostrado na Figura 8.1a, foi projetado para demonstrar como o sistema iria se parecer e se comportar. Nele, é representado um robô operando em l dimensão, podendo andar para frente e para trás. Na Figura 8.1b, apresenta-se o programa de simulação que realiza o aprendizado.

Para obter uma posiçāo no ambiente, que será associada ao objeto localizado na mesma, dois parâmetros são necessários: a distância percorrida e a distância estimada. 
O ponto invariante é dado pela soma destes dois parâmetros. Embora estes parâmetros possam mudar, de acordo com a posição do robô, a posição do objeto alvo em relação ao marco permanece fixa.

(a)

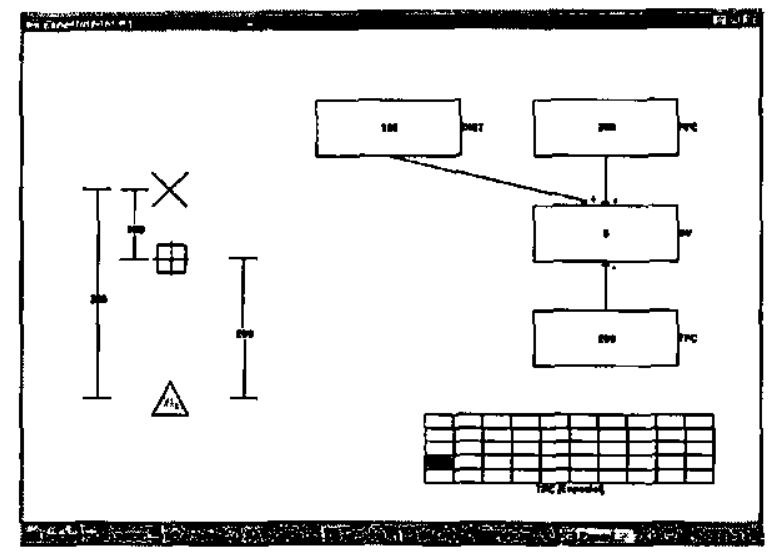

(b)

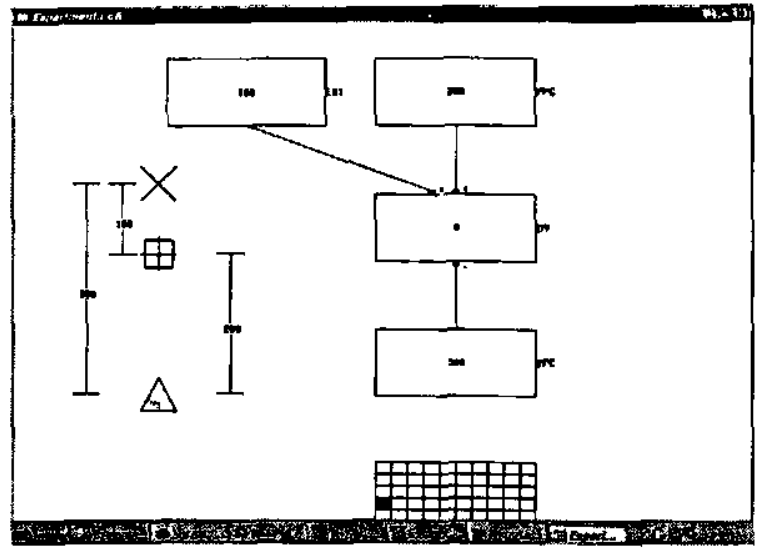

Figura 8.1 - Simulação de uma Rede Neural VAM calibrada.

(a) Representação da interface da implementação proposta

(b) O programa de simulação completado.

Na Figura 8.1, o robô é representado por um quadrado com uma cruz, o marco é representado por um triângulo e o alvo é representado por um ' $\mathrm{X}$ '. A distância entre o marco $\mathrm{e}$ o alvo é sempre fixa, enquanto que as distâncias entre o robô e o marco e o robô e o alvo podem variar.

O objetivo da Rede Neural é estimar a posição do alvo em relação ao marco, dadas as informações sensoriais obtidas da distância entre o robô e o marco e o robô e o alvo. A Rede Neural irá portanto aprender uma operação de soma.

Se os sensores do robô fossem livres de erro, bastaria somar as distâncias obtidas através deles. Como os sensores apresentam erros, torna-se vantajoso utilizar uma Rede Neural.. Como a rede VAM opera com aprendizado on-line, o robô continuará a operar de forma correta, ainda que as características de erro dos sensores mudem ao longo da sua operação, sem requerer paradas para novos treinamentos.

Ainda na Figura 8.1, no lado direito, em cima, está representada uma Rede Neural VAM. Ela é composta de dois módulos PPC, um representando a distância entre o robô e o marco e o outro a distância entre robô e o alvo. O módulo TPC registra a posição alvo a ser aprendida. A diferença entre eles é dada no módulo DV, que dirige o processo de 
aprendizado. Uma descrição mais detalhada da operação geral da rede VAM foi dada no Capítulo 5.

Na parte inferior da Figura 8.1, observa-se a saída da rede VAM, que é a estimativa dada pela rede a respeito da distância entre o marco e o alvo. Cada célula do TPC corresponde a uma determinada distância. Assim, para cada distância entre o marco e o alvo, uma posição diferente neste mapa será ativada.

Este mecanismo corresponde a parte métrica e de direção do mapa cognitivo. Kosslyn (1996) divide a tarefa do cérebro em duas partes: o sub sistema "Onde" (Where) e o sub sistema "O que" (What). Esta Rede Neural estaria implementando o sub sistema "Onde".

Para a implementação do sub sistema "O que", foi escolhida a Rede Neural ART1. O objeto que está localizado em uma determinada posição invariante precisa ser reconhecido. A Rede Neural responsável pelo seu reconhecimento é a rede ART1.

Na Figura 8.2 é apresentada a implementação da Rede Neural ARTl. Em (a), a Rede Neural foi implementada como um programa completo. Posteriormente (b) a rede foi modificada para atuar como um módulo e assim interagir com as outras partes do sistema. As características do objeto são alimentadas na camada $F_{1}$ e a classificação do objeto é dada pela célula ativada na camada $F_{2}$.

(a)

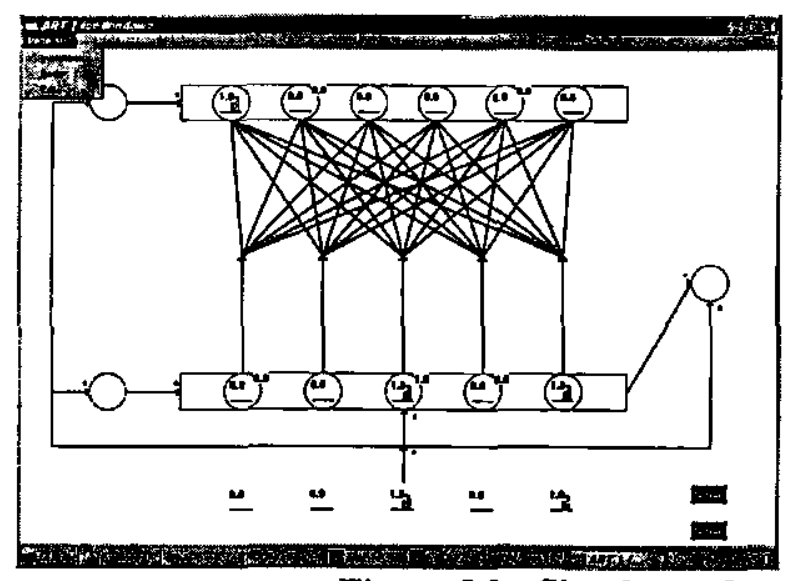

Figura 8.2 - Simulação de uma Rede Neural ART1.

(a) Programa completo ("stand alone") (b) Rede Neural ART1 transformada em módulo. (b)

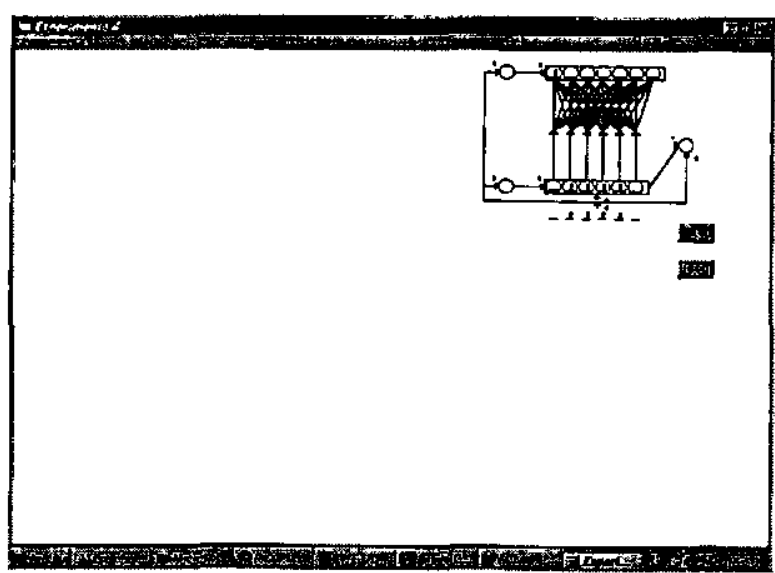

As entradas para a Rede Neural ART1 são as leituras dos sonares do robô. Como a rede ART1 aceita apenas valores binários $(0$ ou 1$)$ e a leitura dos sonares varia entre 0 a 5 
metros, é necessário convertê-las em valores binários. Para isso, emprega-se um simples limiar: Se a distância dada pelo sensor for menor que 1,5 metros, o valor passado para a rede ARTl é 0. Caso contrário é 1.

O limiar de 1,5 metros foi escolhido para facilitar o set-up dos labirintos no robô real, economizando espaço físico. Esta escolha de limiar foi arbitrária, e em outras situações, outros valores podem ser escolhidos.

$\mathrm{Na}$ Figura 8.3, é mostrada a simulação de um robô com 6 sonares. As leituras retornadas pelos sonares são representadas abaixo, em centímetros, e ao lado, entre parêntesis, é apresentado o valor binário correspondente.

O padrão formado pelos valores binários dos sonares é alimentado para uma rede ART1, mostrada do lado direito da Figura 8.3. A rede então é capaz de realizar o aprendizado e o reconhecimento do lugar onde o robô se encontra, a partir da leitura de seus sensores.

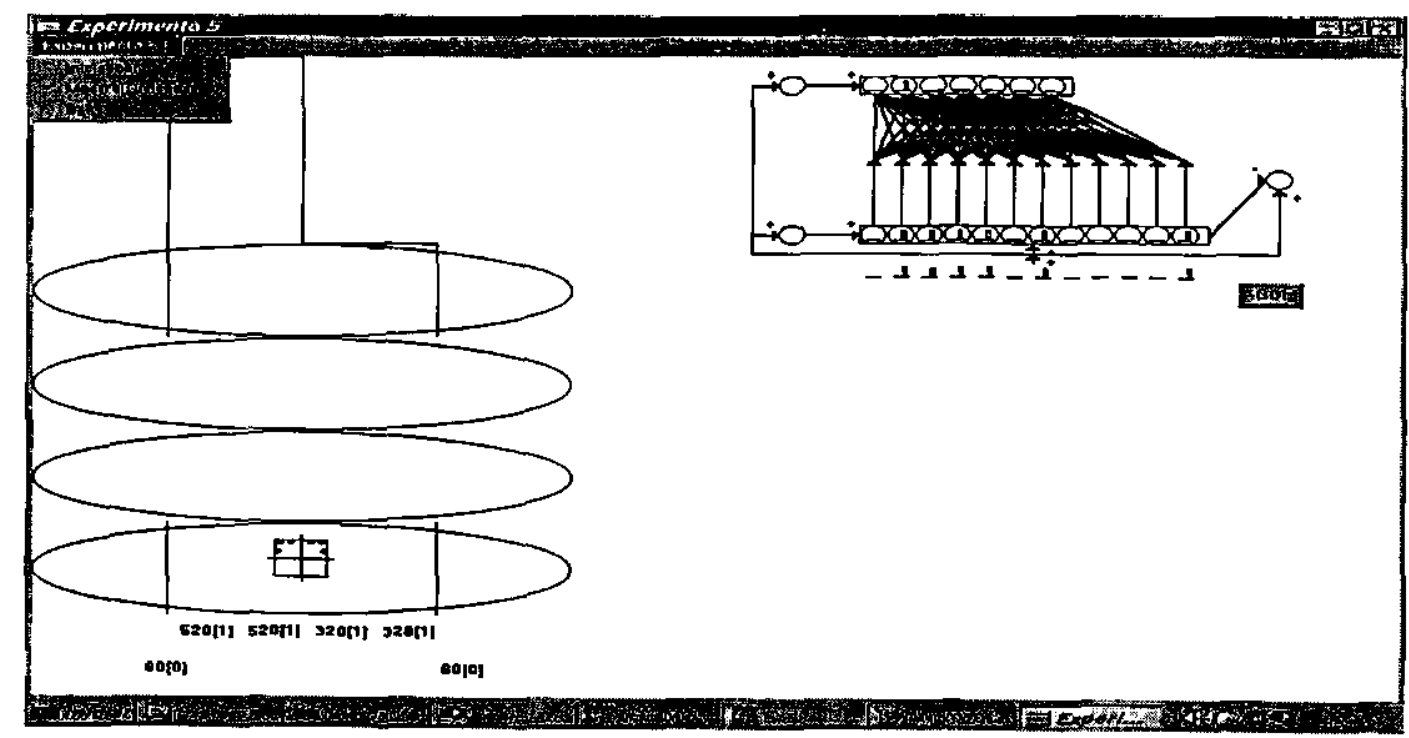

Figura 8.3 - Robô fornece dados sobre o ambiente para a rede ART1.

Nesta simulação, a rede é capaz de distinguir entre 4 diferentes lugares. Estes 4 lugares são delimitados na Figura por elipses.

Um arranjo semelhante é necessário para que o robô possa associar a descrição do lugar (padrão binário obtido a partir dos sensores) com a localização física alocêntrica, para formar o mapa cognitivo.

$\mathrm{Na}$ Figura 8.4, é representada a simulação desta parte complementar do mapa cognitivo. Nesta simulação, os dados provenientes do sonar, em centímetros, são passados 
para a Rede Neural VAM a fim de que os diferentes lugares pelos quais o robô se movimenta sejam categorizados. Os dados binários aparecem na Figura 8.4 embaixo do labirinto onde está o robô, entre parêntesis ao lado dos números que representam as leituras dos sensores. Estes dados binários são desconsiderados neste experimento, pois são relevantes apenas para a rede ART1.

Cada lugar tem uma célula correspondente ativada no mapa TPC. A finalidade da rede é aprender qual célula deverá ser ativada dada a leitura dos sensores.

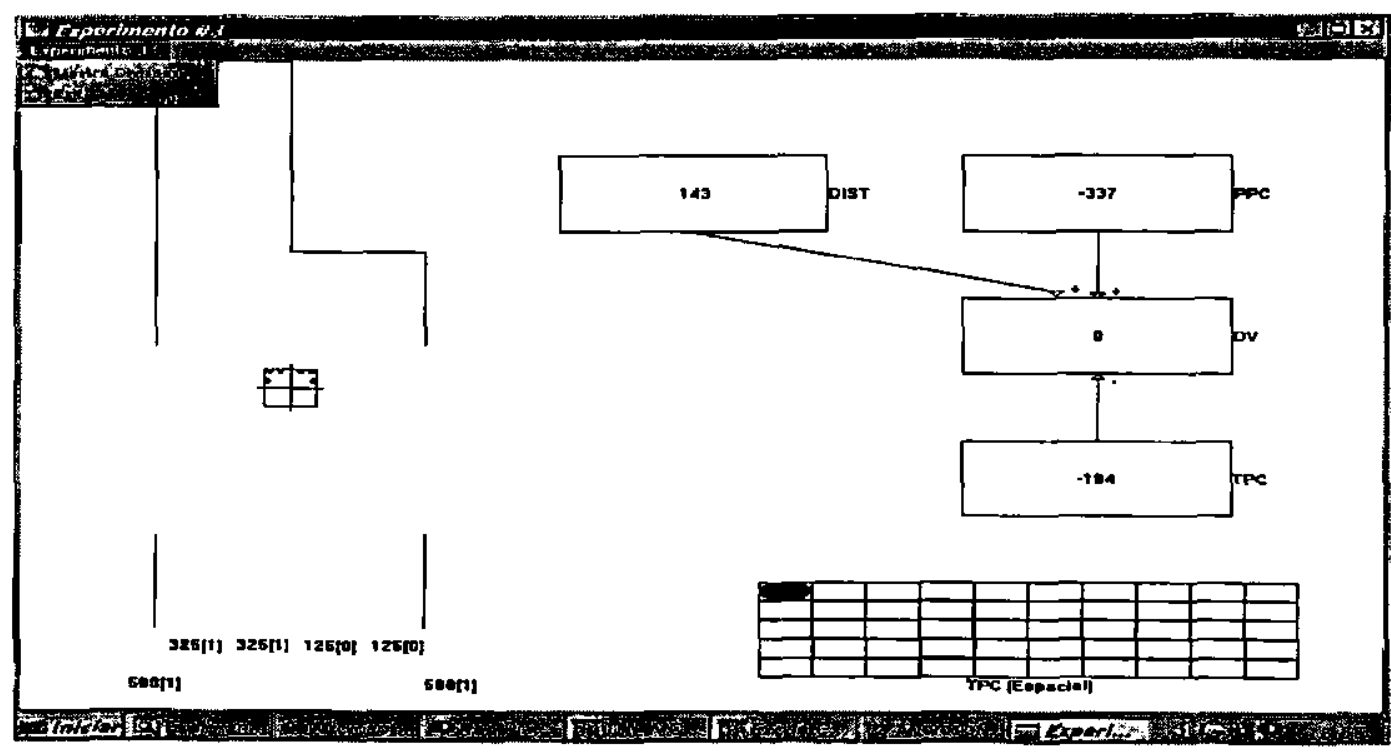

Figura 8.4 - Robô simulado fornecendo dados para uma rede VAM.

Finalmente, estas simulações foram integradas em um sistema único, composto pelas redes VAM e ARTı, que está representado na Figura 8.5. As entradas destas redes são fornecidas pelos sensores de ultra som do robô e elas operam em paralelo.

Um alvo é escolhido pelo róbô. Na Figura 8.5, este alvo é a parede logo em frente ao robô (marcado com um ' $X$ '). Um marco também precisa ser determinado. Nas simulações, ele é o ponto de partida do robô. O marco é representado na Figura 8.5 por um triângulo.

O robô sempre inicia os experimentos na posição do marco. Assim, a medida que o robô anda, é possível saber sua distância em relação ao marco através da leitura dos sensores acoplados às suas rodas (encoders).

O objetivo da rede VAM é determinar a posição ocupada pelo alvo em relação ao marco. Para isso, as entradas fornecidas a rede são a distância do robô ao marco (obtida através dos encoders) e a distância do robô ao alvo (obtida através dos sonares). Uma célula é ativada no TPM da rede VAM correspondente ao lugar ocupado pelo robô. 
Ao mesmo tempo, a rede ART1 recebe a leitura dos sonares, convertidas para valores binários, e fornece em sua saída (camada $F_{2}$ ) uma célula ativada, que corresponde a descrição do lugar. Assim, uma célula da camada $F_{2}$ portanto representa um lugar que contém as características detectadas pela camada $F_{1}$.

A célula ativa no TPC da rede VAM é associada a célula ativa na camada $F_{2}$ da rede ART1. Assim, depois deste treinamento, dada a descrição do lugar (ativação de uma célula na camada $F_{2}$ da rede ART1), obtém-se a localização do lugar, em coordenadas alocêntricas (ativação de uma célula no TPC da rede VAM).

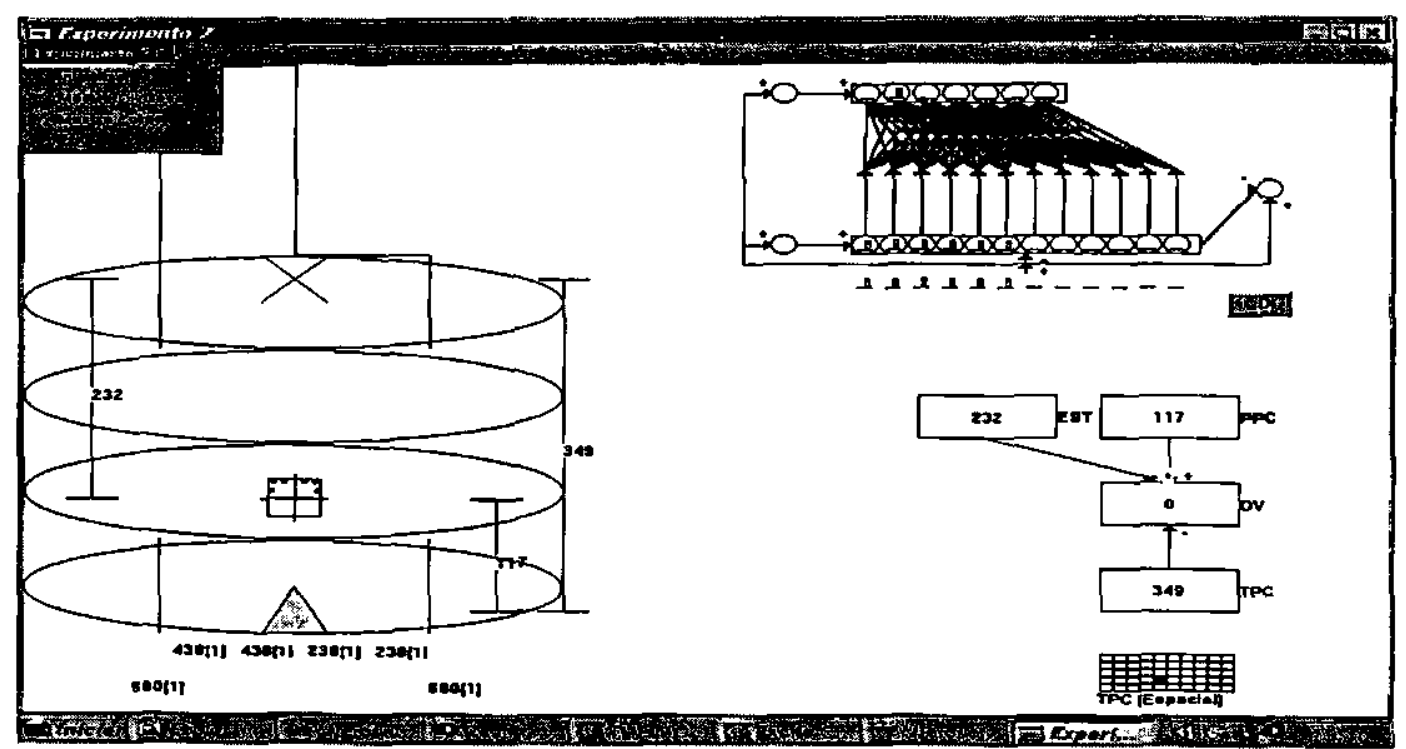

Figura 8.5 - Robô fornece dados a uma rede ART1 e VAM.

A Rede ART1 reconhece os padrões e a rede VAM processa os dados de distância.

Nos experimentos realizados, a rede VAM foi capaz de aprender com perfeição a operação de soma (um mapeamento linear) para dar como resposta à posição alocênctrica de um lugar, dadas as leituras egocêntricas do robô ao alvo e do robô ao marco em coordenadas egocêntricas. Uma representação visual do processo de aprendizado de uma rede VAM deste tipo é apresentado na Figura 8.6.

Na Figura 8.6, as leituras em coordenadas egocêntricas obtidas pelos sensores são convertidas para um mapa TPC, onde cada leitura corresponde à ativação de uma célula diferente do mapa. Estas células do mapa TPC têm conexões com o módulo DV. Enquanto a rede está perfeitamente calibrada, os dois mapas TPC apresentam pesos complementares. Assim, quando um dos mapas aumenta sua ativação, o outro tem a ativação reduzida na mesma proporção, mantendo desta forma a saída da rede fixa e obtendo um mapeamento 
invariante. Na Figura 8.6, as barras representam as conexões aprendidas por um dos mapas TPC (As conexões do outro mapa são idênticas ao final do treinamento).

Para obter o efeito de invariância, a rede VAM distribui os pesos entre os 2 mapas TPC disponíveis. Isto tem o efeito de levar a pesos menores em posições menores (mais a esquerda), e pesos maiores em posições maiores (mais a direita).

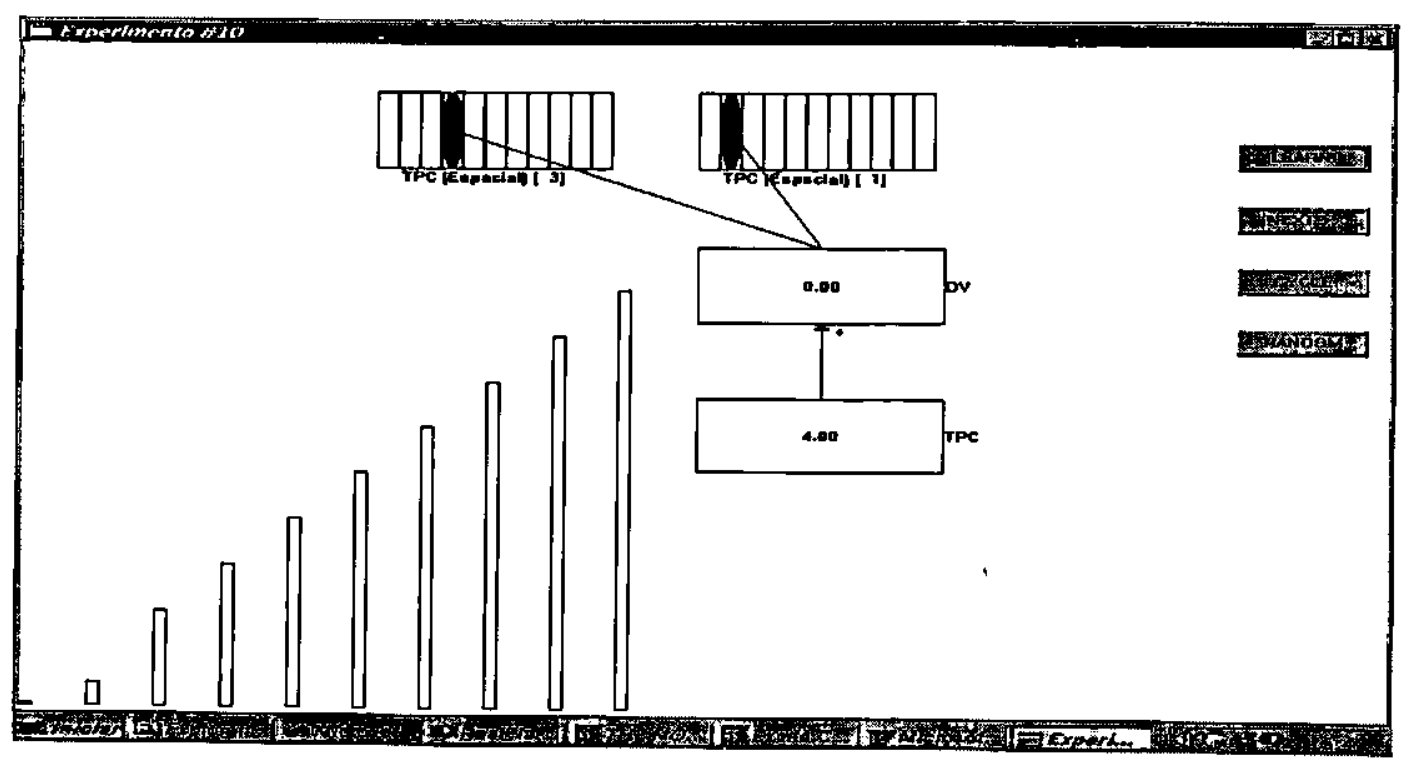

Figura 8.6 - Rede Neural VAM composta por dois mapas espaciais.

As barras representam os pesos de um dos mapas espaciais.

Este sistema foi então testado com o simulador disponível para o robô Pioneer I para um labirinto em uma dimensão, mostrado na Figura 8.7. 


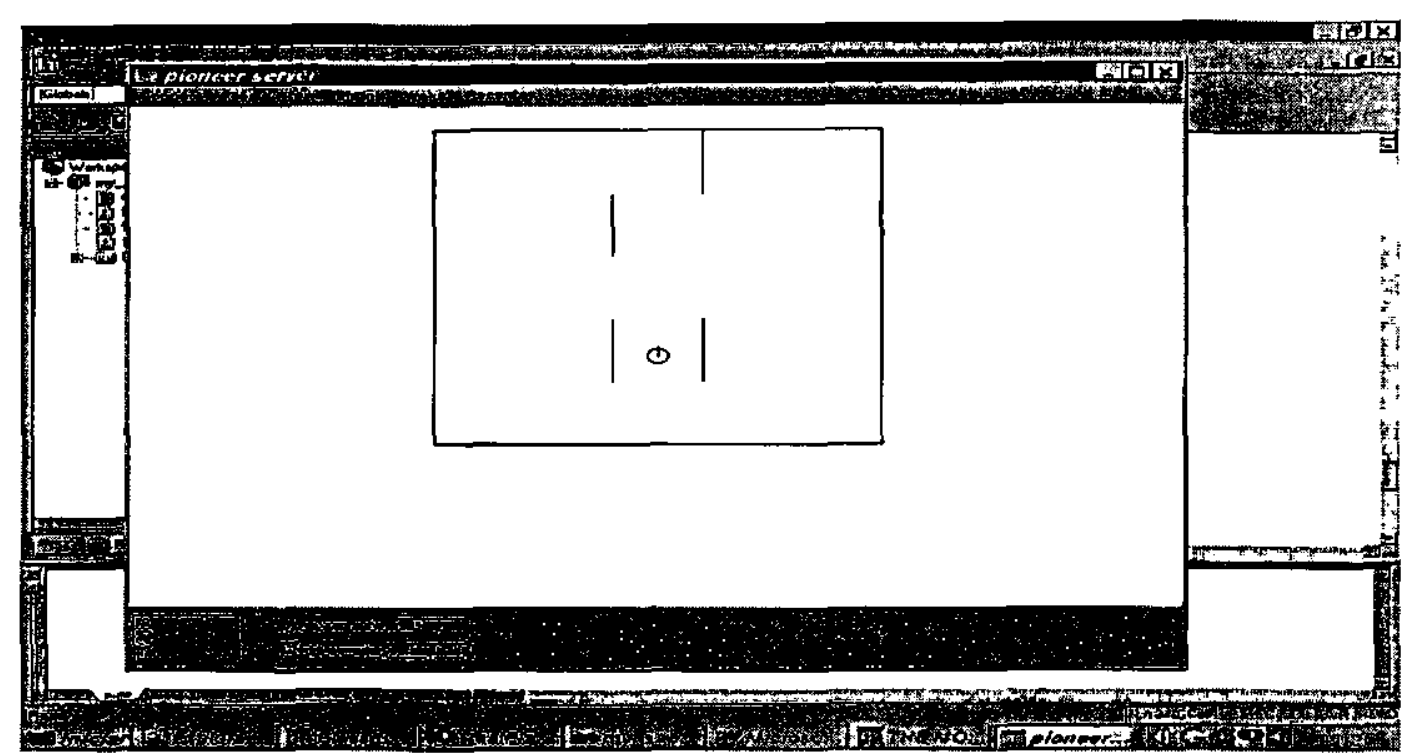

Figura 8.7 - Labirinto utilizado nas simulações do robô em uma dimensão.

$\mathrm{Na}$ simulação apresentada na Figura 8.7, o robô está na posição inicial. Esta posição tem a coordenada 0 . Neste ponto, a leitura do sonar frontal é $3.000 \mathrm{~mm}$. A medida que o robô anda para frente, os encoders das rodas registram seu deslocamento em relação ao ponto de coordenada 0. Desta forma, se o robô se desloca 1 metro $(1.000 \mathrm{~mm})$ o sonar frontal retornará $2.000 \mathrm{~mm}$, e os encoders registrarão $1.000 \mathrm{~mm}$, concluindo-se assim que o alvo está a 3.000 mm da posição inicial, cuja coordenada é 0 .

\subsection{O Robô em Duas Dimensões}

Tendo resolvido o problema da criação de um mapa cognitivo para o robô operando em uma dimensão, o próximo passo foi estender o esquema para duas dimensões.

A Figura 8.8 demonstra o resultado esperado do sistema operando em duas dimensões. Nesta e nas figuras subsequentes, o alvo será representado como um círculo com um ' $\mathrm{X}$ ' inscrito, o marco será representado por um triângulo e o robô será representado por um octógono.

No lado direito da Figura 8.8, está representada uma rede VAM que, a princípio, seria usada para calcular a distância invariante entre o marco e o alvo, da mesma forma como foi feito na operação em uma dimensão. 

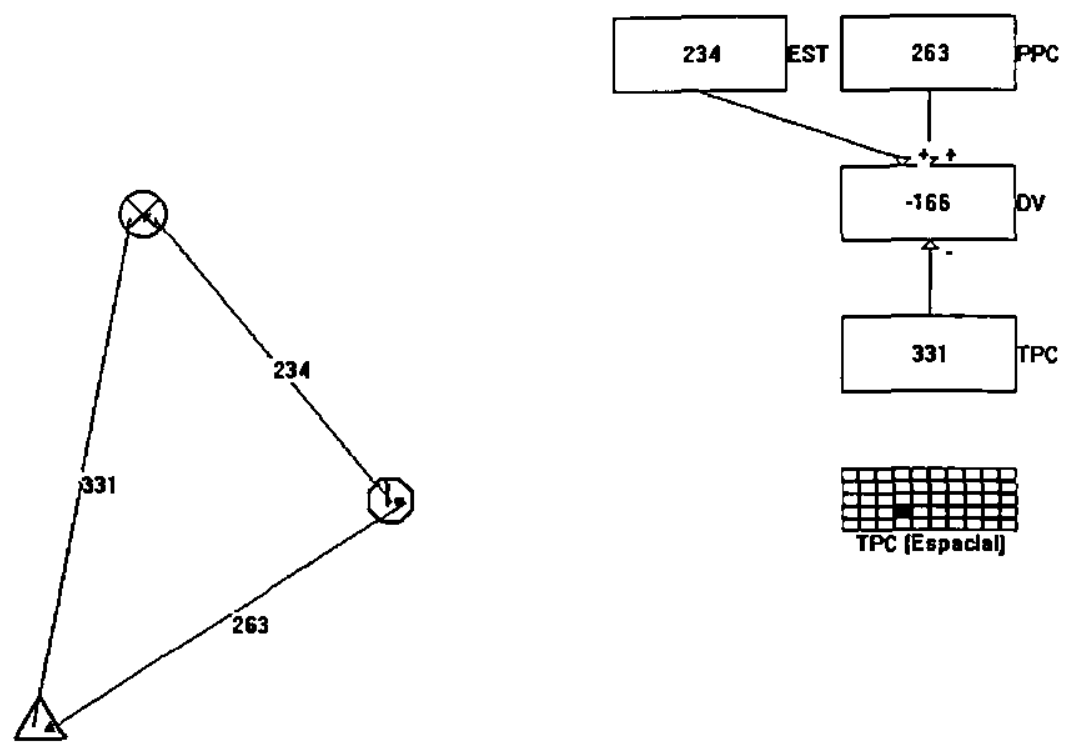

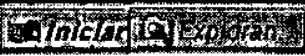

\section{Figura 8.8 - Robô num ambiente em 2 dimensões.}

$\mathrm{O}$ triângulo é o marco, o círculo com X inscrito marca o alvo e o octógono é o robô.

No ambiente em duas dimensões, o alvo está localizado a uma distância 'd' e a um ângulo ' $\theta$ ' em relação ao marco. A combinação de ' $d$ ' e ' $\theta$ ' deve ativar uma determinada célula no mapa de posições TPC em uma rede VAM. Tanto ' $d$ ' quanto ' $\theta$ ' são desconhecidos para o robô.

A Figura 8.9 mostra um triângulo no qual estão representados o robô, o marco e o alvo. Nesta figura, estão representadas as medidas que o robô conhece, que são: (1) A distância entre o robô e o marco (distância 'a'), (2) a distância entre o robô e o alvo (distância 'b') e (3) o ângulo formado entre o marco, o robô e o alvo (ângulo $\alpha$ ). Ao se movimentar, haverá variações nestas 3 medidas conhecidas pelo robô. A partir destas medidas, a distancia e o ângulo invariante devem ser determinados. 
A primeira providência para a implementação de um método para estimar as medidas desconhecidas para o robô é calcular a distância invariante entre o marco e o alvo, a distância 'd'.

Da Trigonometria, é possível utilizar a lei dos cosenos (Equação 8.1) para realizar este cálculo. A lei dos cosenos toma como parâmetros a medida de dois lados de um triângulo qualquer ( $\mathrm{a}$ e b) e o coseno do ângulo cujo vértice é o encontro destes dois lados $(\alpha)$. Como resultado, esta equação fornece a medida do terceiro lado (c). Ver Figura 8.9.

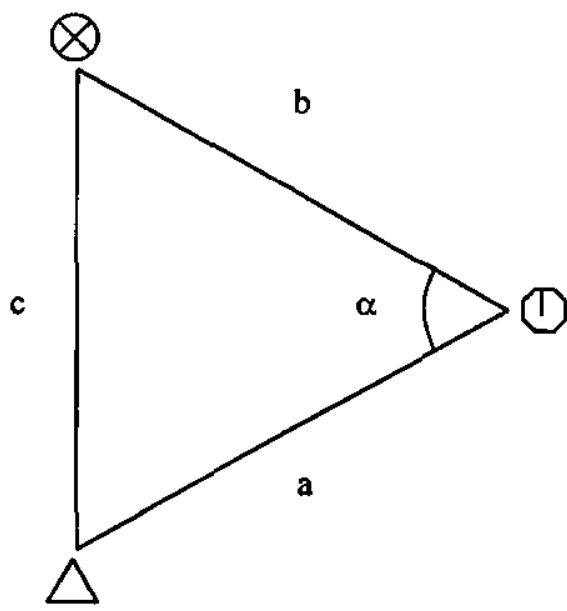

LEI DOS COSENOS:

Figura 8.9 - A equação da lei dos cosenos.

Serve para encontrar a distancia entre o marco e o alvo (distancia c), dada a distância entre o robô e o marco (distância a), a distância entre o robô e o alvo(distância b) e o ângulo entre os lados a e b (ângulo $\alpha$ ).

A operação do cálculo da.lei dos cosenos foi implementada através de uma Rede Neural VAM. Optou-se por utilizar uma Rede Neural porque as leituras dos sensores não são confiáveis, e a Rede Neural seria capaz e determinar a distância correta apesar destas imperfeições.

Depois de um período de mais de 6 meses de trabalho com a rede VAM, ficou claro que ela não seria adequada para este trabalho. Decidiu-se então utilizar em seu lugar uma Rede MLP treinada com o algoritmo Backpropagation, abrindo mão da característica de aprendizado on-line. Os neurônios da saída da Rede MLP tomaram o lugar do mapa TPC da rede VAM. 
Tendo obtido a distância ' $d$ ' entre o marco e o alvo, através da utilização da lei dos cosenos implementada como uma rede MLP, o próximo passo é calcular o ângulo ' $\theta$ ' entre o marco e o alvo.

Novamente, os parâmetros disponíveis para este cálculo são aqueles aos quais o robô tem acesso localmente através de seus sensores: a distância entre o robô e o marco (distância a), a distância entre o robô e o alvo (distância b) e o ângulo entre os lados a e b (ângulo $\alpha$ ).

Aqui, uma decisão de projeto se apresenta para a obtenção do ângulo $\theta$ : como a informação a respeito da distância entre o marco e o alvo já está disponível (pela aplicação da lei dos cosenos), é possível utilizá-la e aplicar novamente a lei dos cosenos, desta vez com a finalidade de obter o ângulo $\theta$ formado entre o marco e o alvo.

Entretanto, este procedimento implica em utilizar um parâmetro (a distância d) que foi determinado a partir da leitura bruta dos sensores por uma Rede Neural.

Proceder desta forma implica em confiar nos parâmetros fornecidos pelos sensores, e na Rede Neural que os processou, o que pode empobrecer a precisão dos resultados.

Preferiu-se, por isso, optar por um método que leve em conta apenas as medidas brutas obtidas a partir dos sensores, e não de um dado pré-processado, mantendo assim os cálculos da distância $\mathrm{d}$ e do ângulo $\theta$ independentes.

Para realizar o cálculo do ângulo invariante entre o marco e o alvo, o ângulo $\theta$, tentouse utilizar a Equação 8.2, apresentada na Figura 8.10.

Uma parte significativa do esforço aplicado neste trabalho foi determinar como esta equação poderia ser utilizada, dadas as restrições impostas pelos sensores e funções de controle de robô disponíveis nas bibliotecas do Pioneer I. Este esforço é relatado no Apêndice A. 


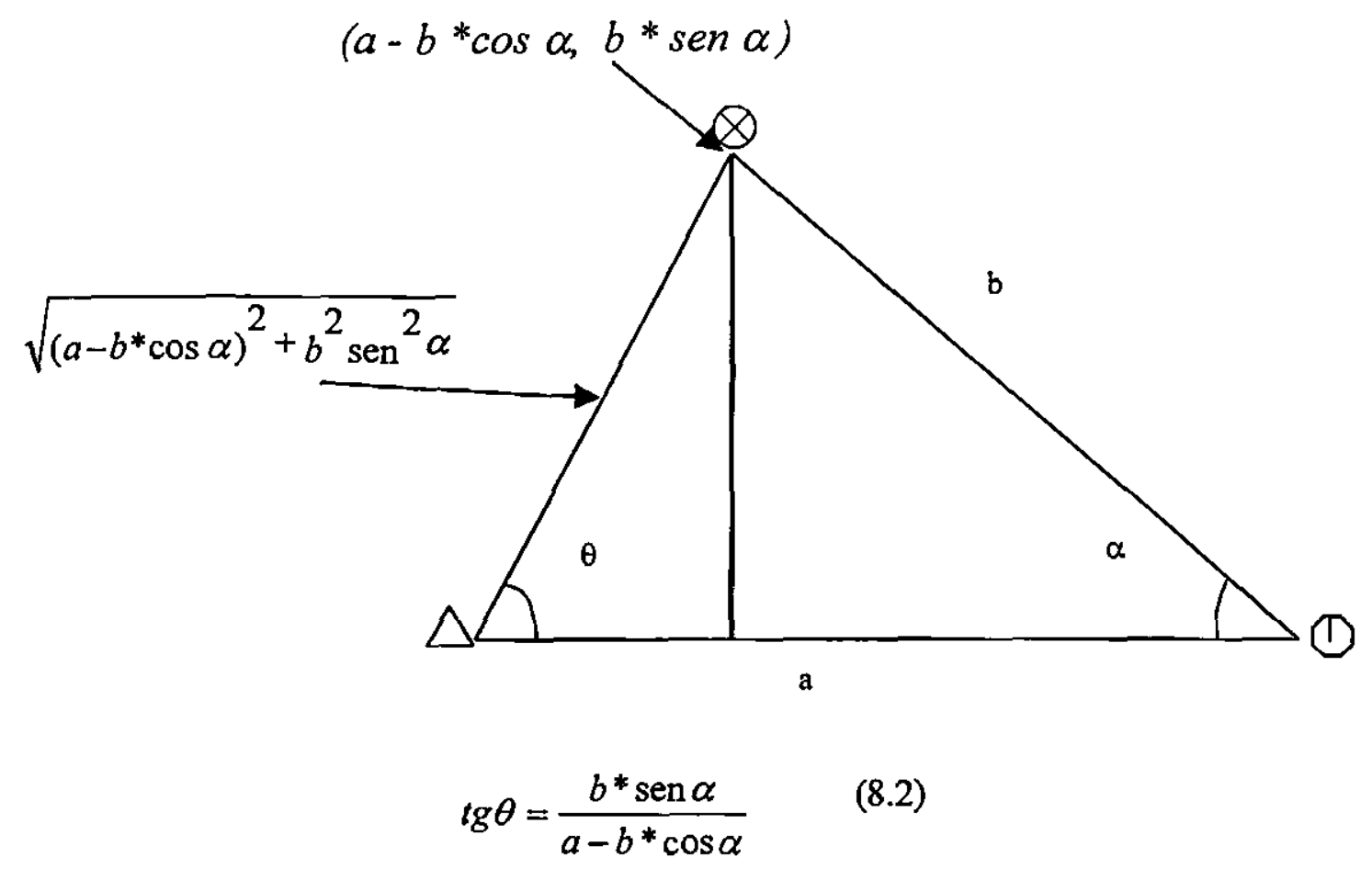

Figura 8.10 - Equação para encontrar o ângulo entre o marco e 0 alvo (ângulo $\theta$ ).

O robô estará localizado no vértice alpha.

No processo de se obter uma solução a fim de aplicar com sucesso a Equação 8.2 ao problema, percebe-se que o problema podia ser resolvido de uma forma muito mais simples. A verdadeira questão era: Qual o ângulo entre o marco e o alvo? Esta questão foi respondida da seguinte forma.

Da Geometria Analítica, sabe-se que dados dois pontos em uma reta, o coeficiente angular desta reta pode ser calculado pela Equação 8.3:

$$
a=\left(\frac{y 2-y 1}{x 2-x 1}\right)
$$

O coeficiente angular ' $a$ ', é igual a tangente do ângulo formado pela reta em relação ao eixo das abcissas, conforme mostra a Figura 8.11: 


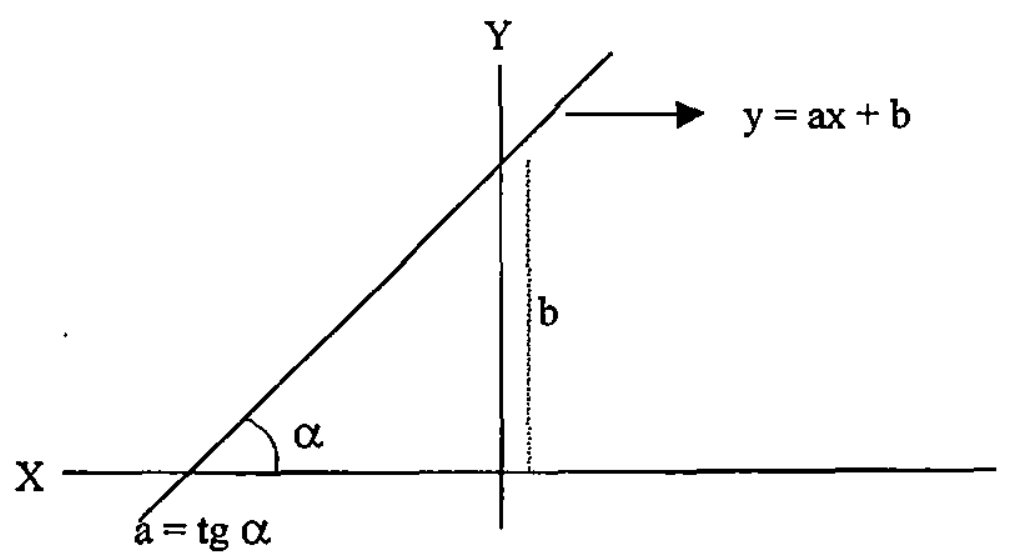

Figura 8.11 - Equação red uzida da reta.

A tangente do ângulo $\alpha$ formado entre a reta e o eixo das abcissas é igual ao coeficiente angular ' $a$ ' da reta, na equação ' $y=a x+b$ '

Ainda da Geometria Analítica, sabe-se que para duas retas serem paralelas, o coeficiente angular de ambas têm que ser iguais, conforme mostra a Figura 8.12:

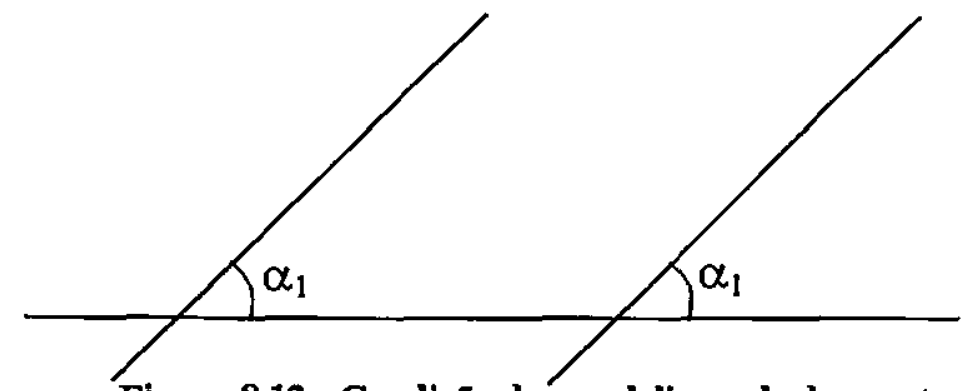

Figura 8.12 - Condição de paralelismo de duas retas.

$O$ coeficiente angular das equações que definem as retas devem ser iguais, ou seja, $\alpha_{1}=\alpha_{2}$.

É necessário notar que a Equação 8.3 pressupõe o uso de coordenadas cartesianas. Por outro lado, o robô somente tem acesso aos ângulos e distâncias entre ele e o marco e entre ele e o artefato. Portanto as coordenadas utilizadas pelo robô são polares. Uma conversão de coordenadas é necessária. Estas conversões são mostradas nas Equações 8.4 e 8.5.

$$
\begin{aligned}
& x=r^{*} \cos \alpha \\
& y=r^{*} \operatorname{sen} \alpha
\end{aligned}
$$

Onde $r$ é a distância entre o robô e o marco ou o artefato, e $\alpha$ é o ângulo formado entre o robô orientado para frente $\left(0^{\circ}\right)$ e o marco ou o artefato. 
Substituindo as Equações 8.4 e 8.5 na Equação 8.3 obtém-se a Equação 8.6, que determina o coeficiente angular de uma reta utilizando coordenadas polares.

$$
a=\frac{r 2 \operatorname{sen} \alpha 2-r 1 \operatorname{sen} \alpha 1}{r 2 \cos \alpha 2-r 2 \cos \alpha 1}
$$

O valor do coeficiente angular, resultado da Equação 8.6, indica a inclinação da reta cujos pontos extremos são o marco $\left(\mathrm{x}_{1}, \mathrm{y}_{1}\right)$ e o artefato $\left(\mathrm{x}_{2}, \mathrm{y}_{2}\right)$, em relação a um plano horizontal ao robô.

Assim, o próprio coeficiente angular é o ângulo invariante formado entre o marco (considerando-se que o marco esteja orientado verticalmente) e o artefato. Esta abordagem elimina a necessidade da aplicação da Equação 8.2 e todos os passos subsequentes, sendo portanto mais vantajosa.

O mapa cognitivo para duas dimensões, portanto, acabou sendo composto por uma Rede Neural MLP e por uma Rede Neural ARTl. A rede MLP informa a localização dos lugares e a rede ART1 informa a descrição dos lugares.

Uma associação é formada entre as duas redes de forma que, dada a descrição de um lugar, sua localização possa ser recuperada. De forma análoga, dada a localização de um lugar, a descrição do mesmo possa ser obtida.

Devido ao longo tempo gasto nesta etapa, não foi possível o desenvolvimento de outras Redes Neurais para desempenhar os papéis dos outros módulos inicialmente propostos para o sistema de navegação completo.

Técnicas mais simples foram empregadas para a implementação dos módulos de navegação e estas técnicas empregam o mapa cognitivo para realizar a tarefa de navegação. A próxima seção mostra os resultados obtidos. 


\subsection{Resultados Experimentais}

Nesta seção são apresentados os resultados dos experimentos realizados utilizando Redes Neurais ART1 e MLP, treinada com o algoritmo Backpropagation. São apresentados também diferentes labirintos percorridos pelo robô. Finalmente são exibidas as trajetórias seguidas pelo robô para cada um dos labirintos.

\subsubsection{Redes Neurais}

Uma Rede Neural do tipo MLP foi treinada para estimar a distância e a posição de um alvo em relação a um marco. Várias topologias de Redes MLP foram treinadas. Em todas elas, havia três entradas (distância do robô ao marco, distância do robô ao alvo e ângulo formado entre o marco e o alvo, sob o ponto de vista do robô) e 2 saídas (ângulo e distância entre o marco e o alvo). Variou-se o número de neurônios na camada oculta a fim de encontrar a rede com melhor desempenho. $O$ resultado deste treinamento é apresentado na Tabela 9.1.

Para as simulações, utilizou-se a ferramenta SNNS, com a taxa de aprendizado de 0.2 e 5.000 ciclos de treinamento. O conjunto de treinamento foi composto de 6.000 pares de valores entrada/saída. Os conjuntos de validação e teste foram compostos de 3.000 pares de valores entrada/saída cada um. Para as entradas e saídas, as distâncias variaram de 0 a 3.000 $\mathrm{cm}(0 \mathrm{~m}$ a $3 \mathrm{~m})$ e os ângulos de $0^{\circ}$ a $359^{\circ}$. Estes valores foram normalizados para a faixa de $0 \mathrm{a}$ 1 antes de serem alimentados à Rede Neural.

Para a geração dos dados, as entradas foram produzidas de forma "aleatória" (através do gerador de números pseudo-randômicos do Microsoft Visual C++ 5.0). Para as Redes Neurais apresentadas na Tabela 9.1, as saídas foram calculadas de acordo com a lei dos cosenos, previamente apresentada neste Capítulo. Na prática, as entradas para a Rede Neural seriam fornecidas pelo robô. 
Treinamento das Redes Neurais MLP

\begin{tabular}{|c|c|c|c|}
\hline $\begin{array}{c}\text { No. de Neurônios } \\
\text { na Camada Oculta }\end{array}$ & SSE & MSE & SSE/o-units \\
\hline 05 & 11.00748 & 0.00183 & 5.50374 \\
\hline 10 & 4.79837 & 0.00080 & 2.39919 \\
\hline 15 & 3.17859 & 0.00053 & 1.58929 \\
\hline 20 & 3.48400 & 0.00058 & 1.74200 \\
\hline
\end{tabular}

Teste das Redes Neurais MLP

\begin{tabular}{|c|c|c|c|}
\hline $\begin{array}{c}\text { No. de Neurônios } \\
\text { na Camada Oculta }\end{array}$ & SSE & MSE & SSE/o-units \\
\hline 05 & 5.49196 & 0.00183 & 2.74598 \\
\hline 10 & 2.68576 & 0.00090 & 1.34288 \\
\hline 15 & 3.31908 & 0.00055 & 1.65954 \\
\hline 20 & 1.93526 & 0.00065 & 0.96763 \\
\hline
\end{tabular}

Tabela 9.1 - Resultados do treinamento e do teste de Redes Neurais (0\% de erro nos sensores).

Os resultados apresentados na Tabela 9.1 pressupõem que os sensores do robô não apresentam erro sistemático, ou seja, suas leituras contêm $0 \%$ de erro.

$\mathrm{Na}$ prática, um robô apresenta imperfeição nos sensores. Para verificar o comportamento da Rede Neural em uma situação como esta, acrescentou-se um erro de $20 \%$ às entradas e repetiu-se o treinamento da RNA com os mesmos parâmetros citados acima. $\mathrm{O}$ resultado é apresentado na Tabela 9.2.

Treinamento das Redes Neurais MLP

\begin{tabular}{|c|c|c|c|}
\hline $\begin{array}{c}\text { No. de Neurônios } \\
\text { na Camada Oculta }\end{array}$ & SSE & MSE & SSE/o-units \\
\hline 05 & 11.37396 & 0.00190 & 5.68698 \\
\hline 10 & 4.82733 & 0.00080 & 2.41336 \\
\hline 15 & 3.78068 & 0.00063 & 1.89034 \\
\hline 20 & 3.26508 & 0.00054 & 1.63254 \\
\hline
\end{tabular}

Teste das Redes Neurais MLP

\begin{tabular}{|c|c|c|c|}
\hline $\begin{array}{c}\text { No. de Neurônios } \\
\text { na Camada Oculta }\end{array}$ & SSE & MSE & SSE/o-units \\
\hline 05 & 5.71324 & 0.00190 & 2.85662 \\
\hline 10 & 2.06328 & 0.00069 & 1.03164 \\
\hline 15 & 1.60855 & 0.00054 & 0.80428 \\
\hline 20 & 1.41948 & 0.00047 & 0.70974 \\
\hline
\end{tabular}

Tabela 9.2 - Resultados do treinamento de Redes Neurais ( $20 \%$ de erro nos sensores). 
Um robô real pode utilizar-se de um sensor de visão para detectar os artefatos em seu ambiente. A tarefa dos sensores de ultra-som é determinar a que distância esta artefato está localizado. A forma mais fácil de se fazer isso, é girar o robô de modo que ele fique frente a frente com 0 artefato, e utilize o sensor frontal para obter a estimativa de distância. Isto porque estando frente a frente com 0 artefato, maximiza-se a probabilidade do sensor captar 0 eco de ultra-som. Resultados experimentais para o robô Pioneer I demonstram que leituras dos sensores de ultra-som deterioram quando esta condição não é atendida (Sahin \& Gaudiano, 1998).

Os resultados mostrados na Tabela 9.1 indicam que uma Rede Neural do tipo MLP é capaz de aprender a estimar o ângulo e a distância a partir da leitura de sensores com uma baixa taxa de erro, aceitável para esta aplicação.

Já os resultados da tabela 9.2 demonstram que a rede é capaz de ignorar erros sistemáticos cometidos pelos sensores, fornecendo uma resposta correta, equivalente às obtidas com a utilização de sensores perfeitamente calibrados. A taxa de erro foi escolhida como $20 \%$, uma vez que este é um valor superior às piores taxas apresentadas pelos sensores utilizados no robô Pioneer I.

Na próxima seção, são apresentados resultados obtidos com um robô equipado com as redes neurais ART1 e MLP em labirintos simulados. As performances obtidas são comparadas com aquelas obtidas por um robô treinado com uma outra abordagem, mas atuando em labirintos simulados semelhantes. 


\subsubsection{Labirintos Testados}

Foram utilizados 7 diferentes labirintos para avaliar o desempenho do robô na tarefa de navegação. Seis destes labirintos (Números 1 a 6) foram criados de acordo com aqueles utilizados por Braga (1998), de modo a possibilitar a comparação do desempenho do método de navegação apresentado naquele trabalho com o método proposto nesta dissertação. $O$ outro labirinto (Labirinto 7) foi utilizado para o teste do robô em uma única dimensão. Os sete labirintos são mostrados na Figura 8.13.

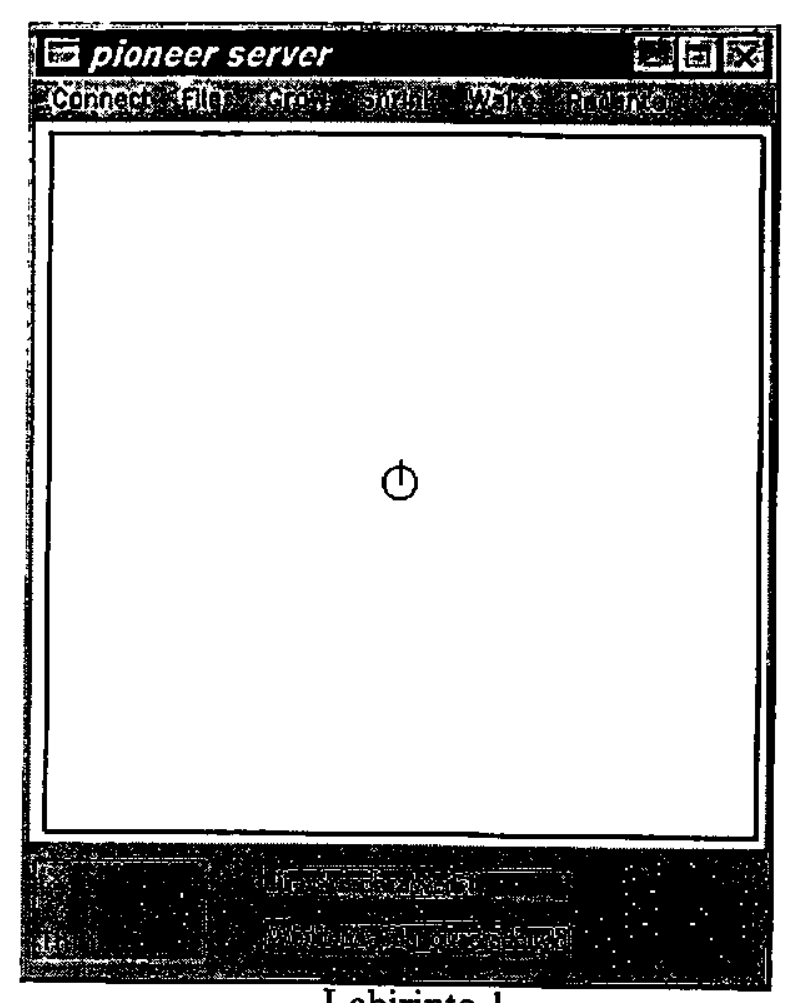

Labirinto 1

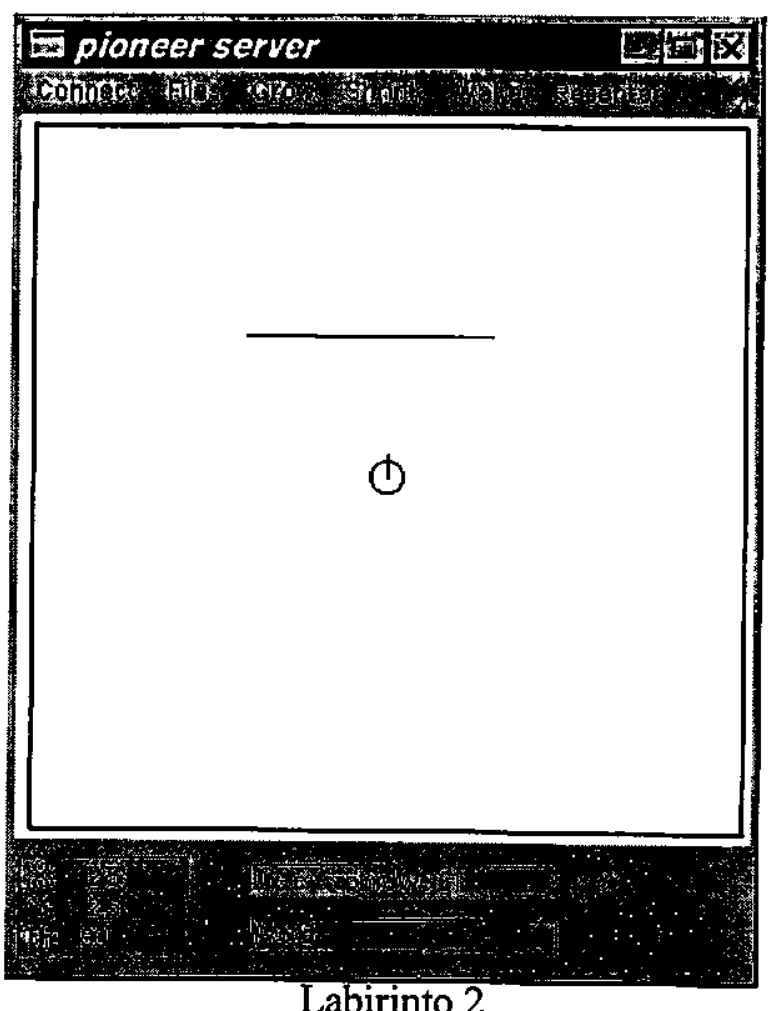

Labirinto 2

Figura 8.13 - Labirintos utilizados no teste do robô na tarefa de navegaçāo. 
Labirinto 3
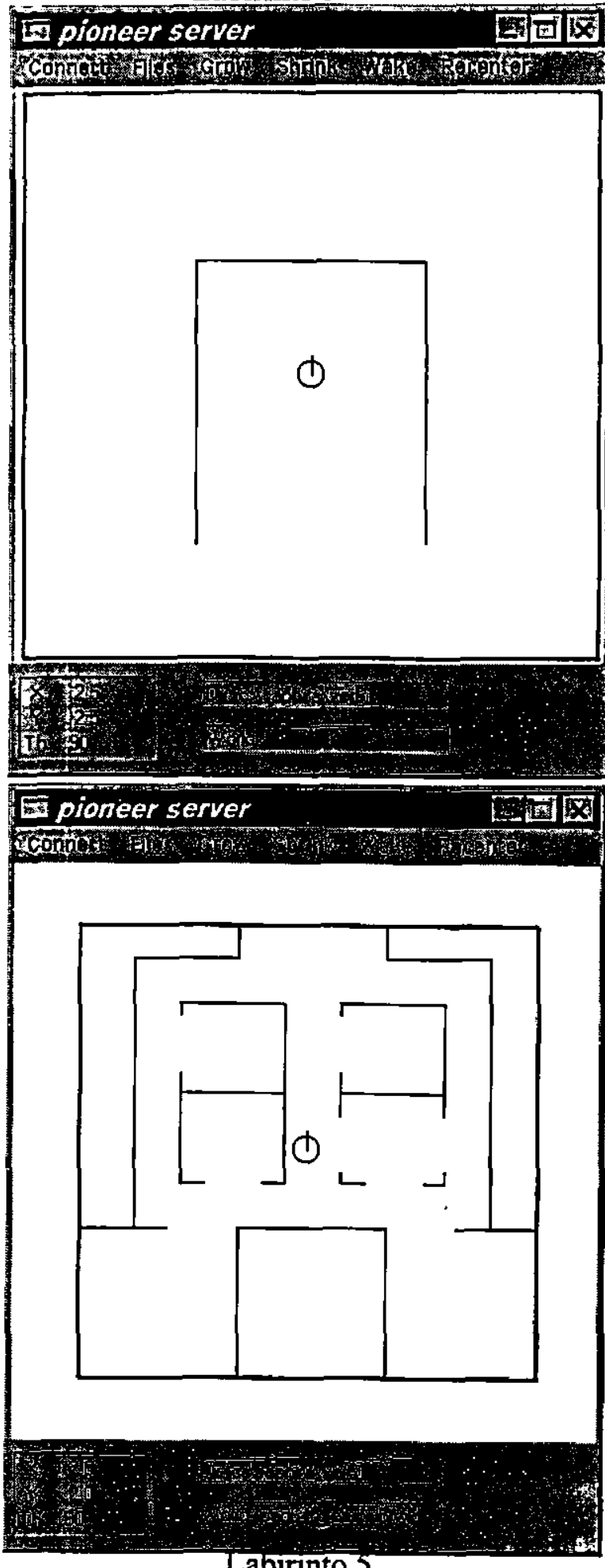

Labirinto 5
Labirinto 4
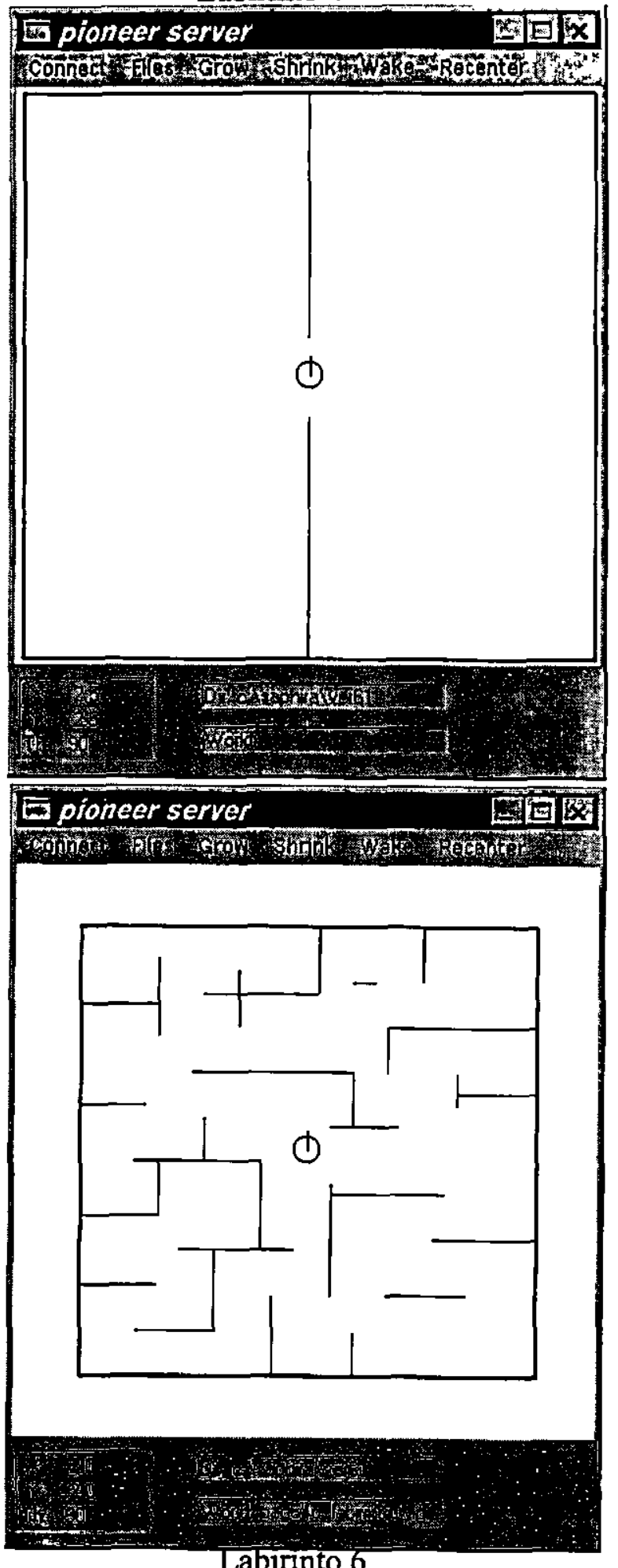

Labirinto 6

Figura 8.13 (cont.) - Labirintos utilizados no teste do robí ua tareıa ue uavegação. 


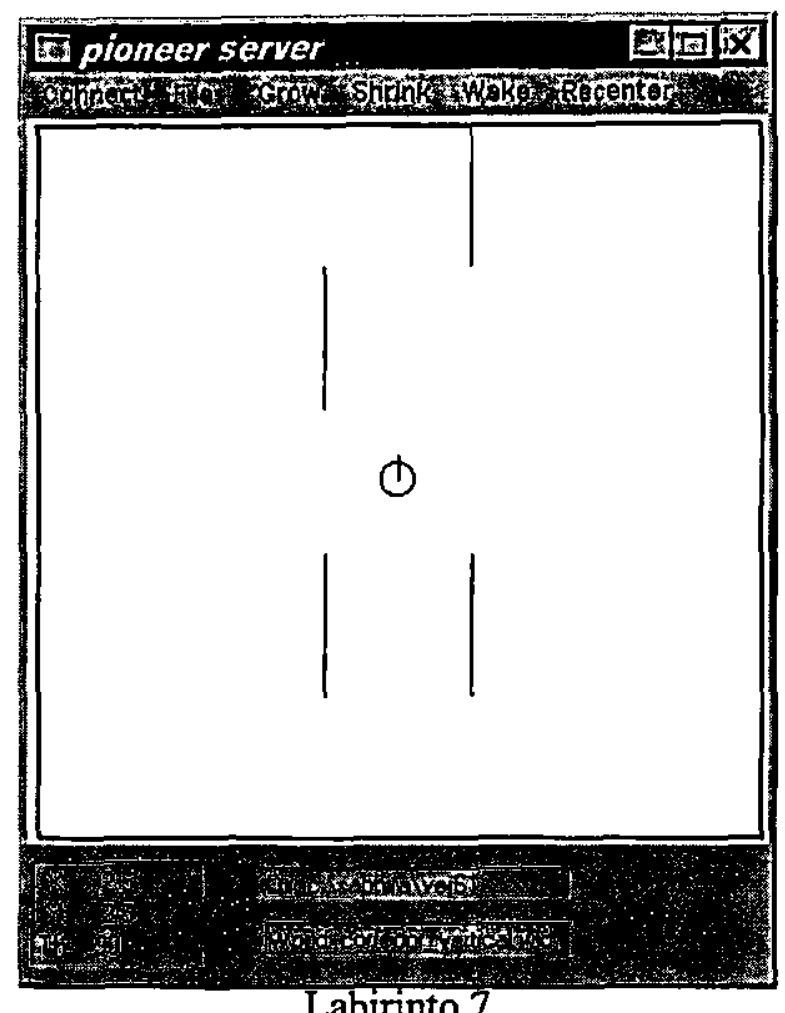

Figura 8.13 (cont.) - Labirintos utilizados teste do robô na tarefa de navegação.

O Labirinto 1 é um caso especial onde não existem obstáculos no ambiente. O robô utilizando mapa cognitivo simplesmente segue uma linha reta em direção ao alvo. Tanto o Labirinto 1 quanto o Labirinto 3 são apresentados em Braga (1998), porém, naquele trabalho, não são mostrados resultados utilizando estes labirintos. Resultados para os Labirintos 1 e 3 obtidos com o sistema proposto são mostrados na Figura 8.14.

Estes labirintos, por sua simplicidade, fomecem um bom ponto de partida para a explicação do método utilizado pelo robô para o mapeamento do ambiente e subsequente busca pelo alvo.

No Labirinto 1, mostrado na Figura 8.14a, os sensores do robô têm alcance suficiente para mapear todo o labirinto a partir de sua posição inicial. A posição inicial é associada ao ponto de partida, de coordenadas $(0,0)$. O robô realiza uma rotação de $360^{\circ}$ no lugar e as paredes percebidas pelos sensores são associadas às respectivas coordenadas. Por exemplo, a parede do lado direito está localizada de $(0,5000)$ a $(5000,5000)$ em coordenadas cartesianas.

Uma vez tendo sido mapeado o labirinto, o usuário poderá clicar com o mouse em uma posição qualquer do labirinto, indicando um alvo para o robô. Como o alvo estará dentro 
do alcance dos sensores do robô, ele pode se dirigir ao alvo simplesmente seguindo uma linha reta, como acontece na Figura 8.14a. Nesta Figura e nas próximas, a trajetória seguida pelo robô é indicada pela linha pontilhada. Os pontos que aparecem na frente ( 5 pontos) e ao lado do robô (um ponto de cada lado) representam a leitura dos sonares.

(a)

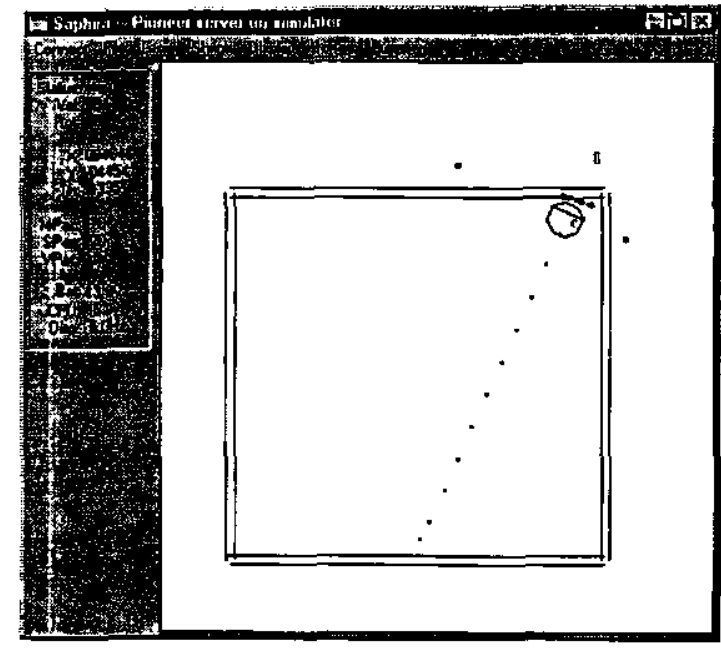

(b)

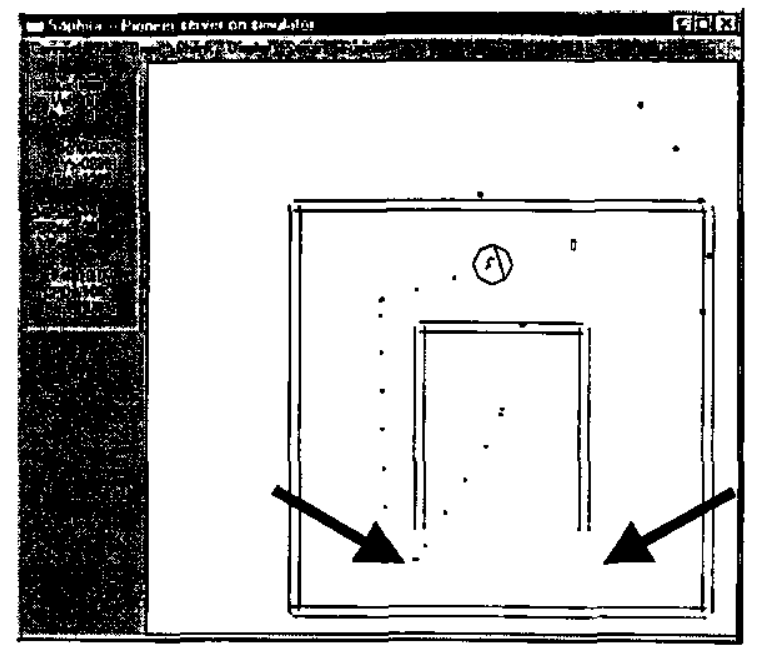

Figura 8.14 - Exemplos do robô navegando nos labirintos 1 (a) e 3 (b).

No Labirinto 3, apresentado na Figura 8.14b, a situação é mais complexa. A posição inicial do robô é no meio do labirinto. Novamente, a posição inicial será associada com as coordenadas $(0,0)$. Ele irá mapear os artefatos que estão dentro do alcance dos sensores, que são as três paredes que formam um $U$ invertido no centro do labirinto. Para isso, novamente o robô realiza uma rotação de $360^{\circ}$ no lugar. Cada uma destas paredes será associada a uma coordenada.

No processo de mapeamento, o robô percebe que as duas paredes paralelas que formam o $U$ invertido não estão conectadas, percebendo assim os pontos de escape assinalados pelas setas na Figura $8.14 \mathrm{~b}$.

Estes pontos de escape são registrados, e ficam em uma "agenda de exploração".

Depois que o local atual foi aprendido, um ponto nesta agenda de exploração que esteja mais próximo da posição atual do robô é recuperado e o robô se locomove para lá.

Chegando a este ponto, o processo de exploração é repetido até que todo o labirinto tenha sido aprendido. $\mathrm{Na}$ fase de navegação, o robô utiliza este conhecimento acumulado para atingir o alvo a partir de uma posição arbitrária, como no exemplo da Figura 8.14b. 
Um exemplo completo tanto da fase de exploração quanto da fase de navegação é fornecido na Seção 8.5 .

A comparação dos desempenhos obtidos pelos dois métodos foi realizada utilizandose, para cada labirinto, a mesma tarefa de navegação. $O$ resultado da comparação pode ser visto nas Figuras 8.15 a 8.18. Os labirintos ou trajetórias da esquerda são aqueles apresentados por Braga (1998) e os da direita são os obtidos pelo robô utilizando o mapa cognitivo.

(a)

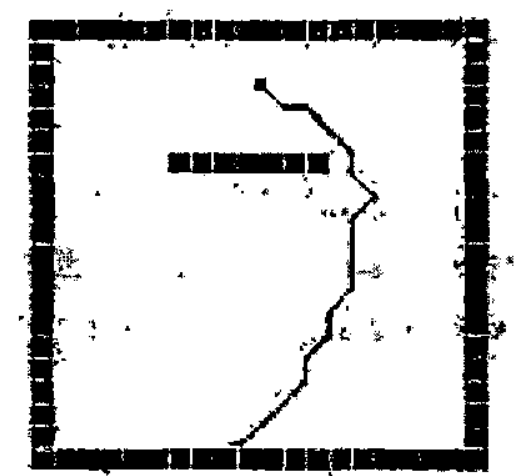

(b)

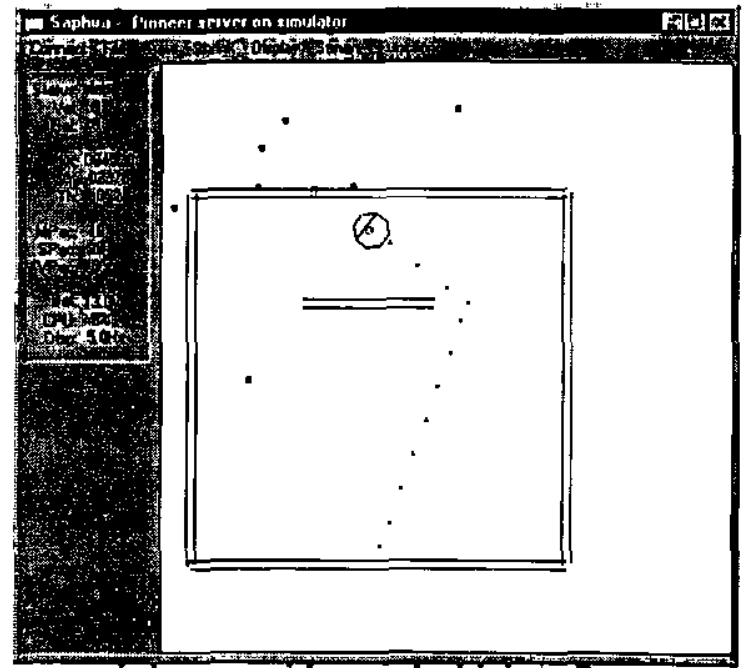

Figura 8.15 - Comparação entre os caminhos seguidos no tabírinto 2.

(a) Trajetória obtida por Braga (1998). (b) Trajetória obtida neste trabalho.

No Labirinto 2, mostrado na Figura 8.15, o desempenho de ambos os robôs é semelhante. Ambos tentam desviar do obstáculo e, após o desvio, vão de encontro ao alvo. A diferença entre eles está na fase de aprendizado. O método proposto explora todo o labirinto para aprendê-lo, enquanto que em Braga (1998) o robô só precisa aprender a rota que leva o robô do ponto inicial ao alvo.

Se, por um lado, o método proposto realiza explorações que não têm a ver com uma meta, potencialmente gastando mais tempo na fase de exploração, este investimento pode ser recuperado com a habilidade de utilizar este conhecimento acumulado para realizar trajetórias em direção a vários alvos. Em Braga (1998), o robô realiza uma economia na fase de exploração, ao custo de este conhecimento servir apenas para atingir um único alvo. 
(a)

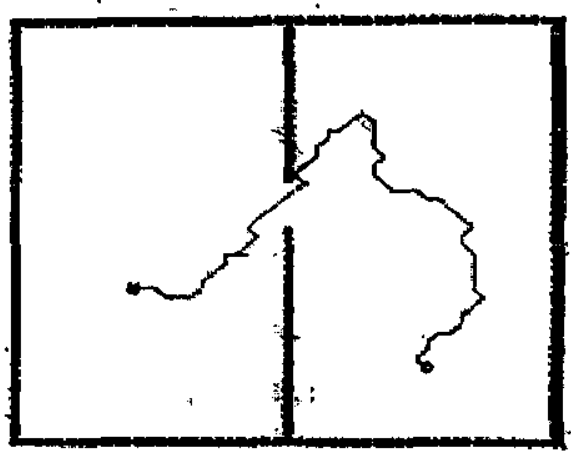

(b)
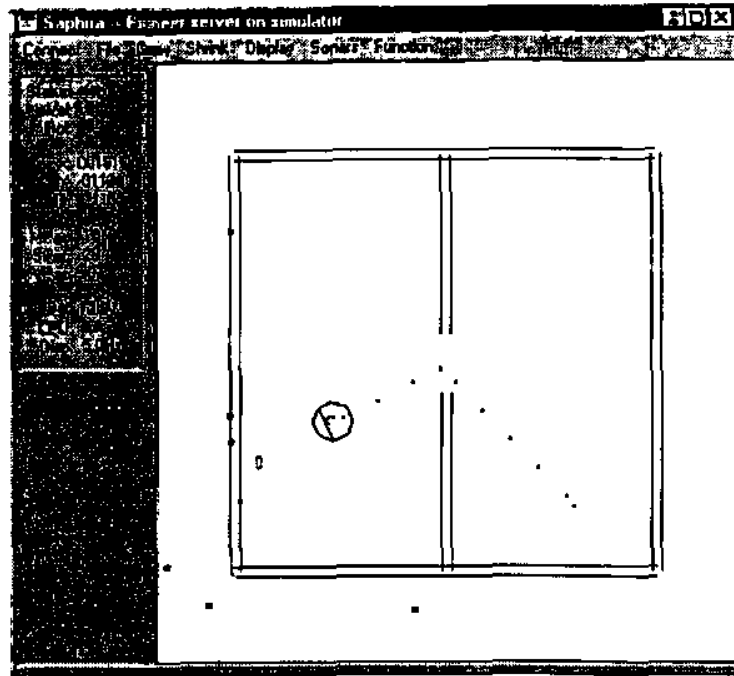

Figura 8.16 - Comparação entre os caminhos seguidos no Labirinto 4.

(a) Trajetória obtida por Braga (1998). (b) Trajetória obtida neste trabalho.

No labirinto 4, mostrado na Figura 8.16, pode ser observado que o método proposto tende a andar em linhas retas. Neste caso específico, a trajetória foi mais eficiente, mas em geral, esta característica de andar em linhas retas nem sempre irá gerar boas trajetórias.

(a)

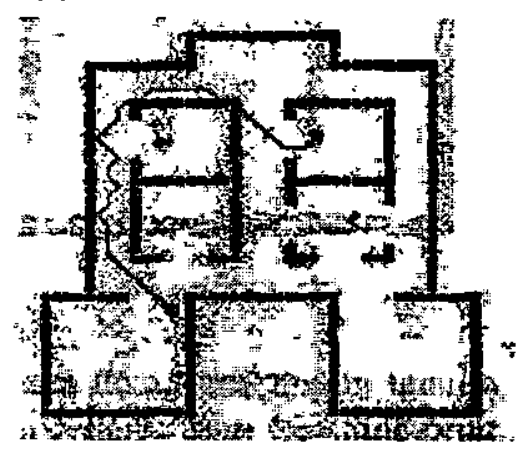

(b)

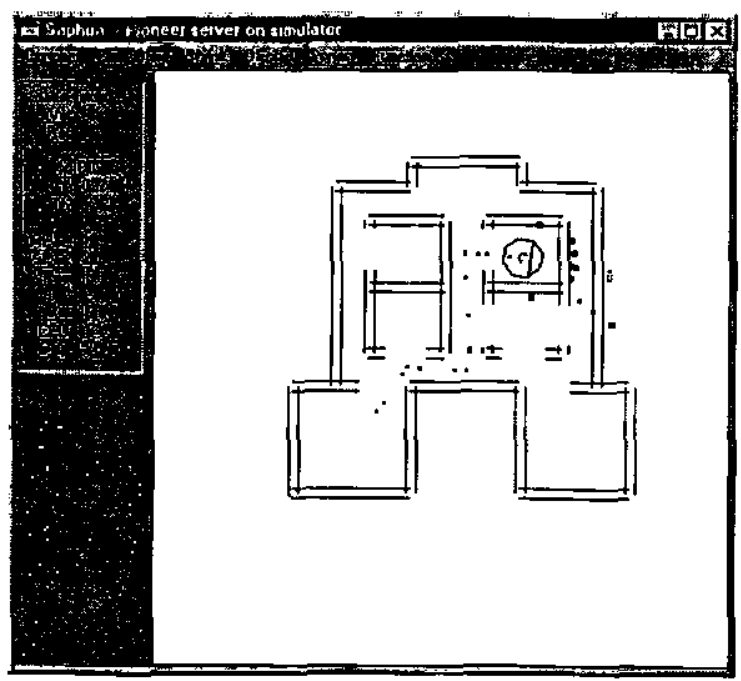

Figura 8.17 - Comparação entre os caminhos seguidos no Labirinto 5.

(a) Trajetória obtida por Braga (1998). (b) Trajetória obtida neste trabalho.

$\mathrm{Na}$ Figura 8.17, os robôs seguiram caminhos diferentes. Não foi possível comparar o comprimento das trajetórias, mas pode-se notar que a trajetória obtida em Braga (1998) apresenta poucos desvios, o que pode favorecer o robô em termos de velocidade. Esta é uma 
área de pesquisa onde o método proposto poderia avançar, pois trajetórias com poucos desvios são ideais para que o robô possa aumentar a velocidade de navegação.

(a)

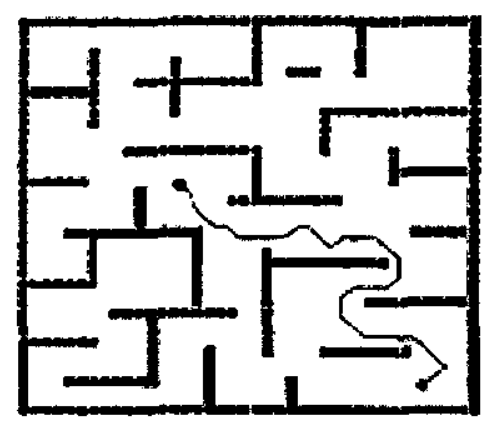

(b)

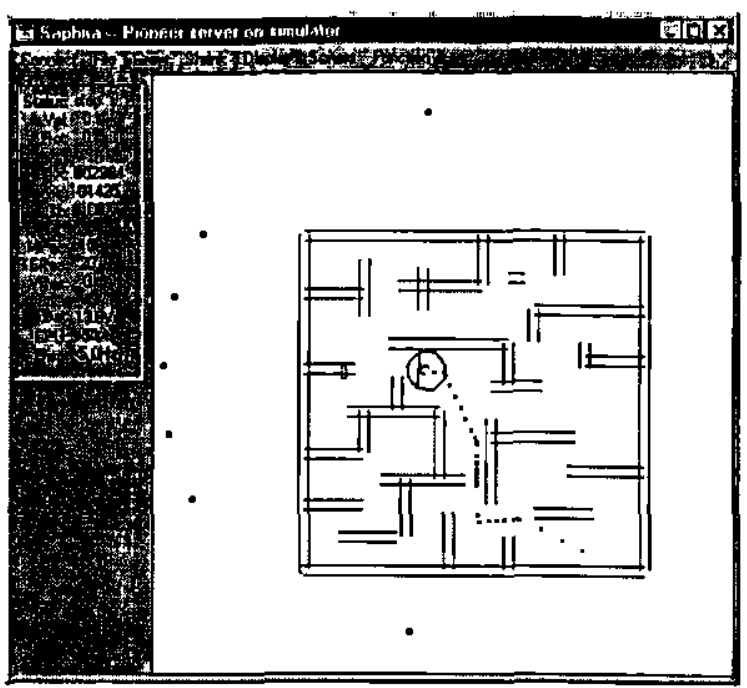

Figura 8.18 - Comparação entre os caminhos seguidos no Labirinto 6.

(a) Trajetória obtida por Braga (1998). (b) Trajetória obtida neste trabalho.

No Labirinto 6, a trajetória obtida pelo método proposto parece ser ligeiramente menor, porém, novamente, uma comparação objetiva não é possível. No geral, os métodos obtiveram resultados semelhantes, sendo que nenhum ficou preso em mínimos locais.

Na próxima Seção, é desenvolvido um exemplo completo e mais detalhado sobre o processo de aprendizado e navegação do robô, utilizando o Labirinto 7 como cenário. 


\subsection{Um Exemplo Completo do Sistema de Navegação}

A tarefa de navegação é dividida em 2 partes. Na primeira parte, o robô anda pelo labirinto e aprende sua estrutura. Na segunda parte, o usuário indica um lugar como alvo para o robô e este tem que sair do ponto onde se encontra e ir até o alvo.

Nesta Seção, será apresentado um exemplo completo do Sistema de Navegação implementado, utilizando-se o labirinto mais simples de modo a facilitar o entendimento. $O$ labirinto em questão é o de número 7 , já apresentado em Seções anteriores. O mesmo é mostrado na Figura 8.19.

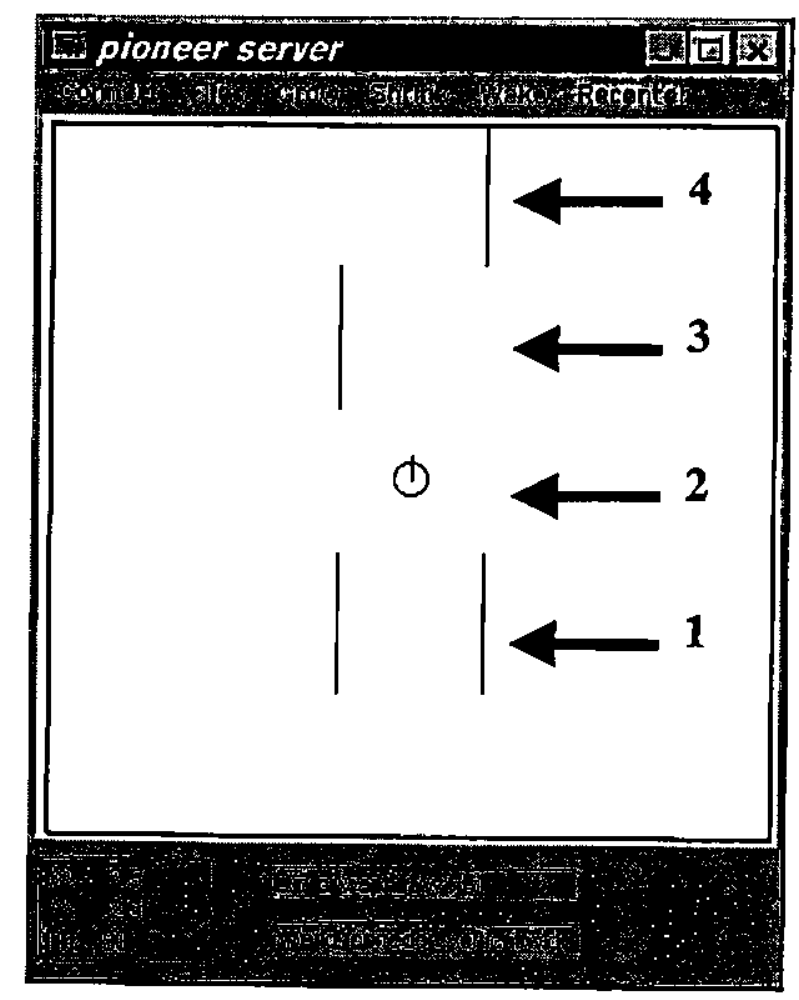

Figura 8.19 - O Labirinto 7, um simples labirinto exemplificando o Sistema de Navegação. As setas numeradas marcam os lugares percebidos como diferentes entre si pelo robô. 


\section{Tarefa 1: Aprender a Estrutura do Labirinto}

Como posição inicial, o robô é colocado em uma extremidade do labirinto. Este será considerado o marco, ou ponto origem $\left(0^{\circ}, 0 \mathrm{~m}\right)$.

Para cada ponto onde o robô estiver localizado, incluindo a origem, o lugar é sensoreado e a leitura dos sensores é alimentada para uma Rede Neural ART1. Após o processamento, esta Rede Neural irá apresentar em sua camada F2 um único neurônio ativado, que representa o lugar onde o robô está localizado.

As coordenadas do lugar onde o robô está são dadas por uma Rede Neural MLP. A entrada para esta rede é composta da leitura dos sensores. Para o caso de uma dimensão, esta rede apenas repete em sua saída as entradas recebidas. A saída da rede MLP é transformada em um mapa de posições alvo, TPM. No mapa TPM, apenas uma célula está ativa por vez. Esta célula representa a localização do robô.

De posse das ativações nas duas Redes Neurais, o próximo passo é associar as células ativas de ambas as redes.

Depois de realizar este processamento para o local atual, o robô deve procurar um lugar no labirinto que ainda não tenha sido explorado e se move para lá, onde o processo recomeça. O final da exploração se dá quando não existirem mais lugares inexplorados no labirinto.

Para o caso específico do labirinto 7, o robô foi colocado no ponto marcado com um '2' na Figura 8.19 e andou a uma velocidade baixa e constante para frente e para trás três vezes, passando por todos os locais numerados na Figura 8.19 .

\section{Tarefa 2: Navegar até o Alvo}

Uma vez terminado o processo de aprendizado do labirinto, o usuário posiciona o robô em um lugar qualquer do labirinto e indica o lugar onde quer que o robô vá. Esta indicação é uma descrição do lugar, nos termos dos sensores do robô.

No labirinto 7, apenas os sensores laterais do robô foram utilizados para descrever o ambiente. A leitura destes sensores varia de $0 \mathrm{~cm}$ a $3000 \mathrm{~cm}$. Como a rede ART1 somente aceita valores binários, estas leituras tiveram que ser transformadas em valores binários. Isto foi feito através da escolha de um limiar, neste caso, $1,5 \mathrm{~m}$. Se a leitura do sonar fosse menor que $1,5 \mathrm{~m}$, significa que existe uma parede próxima, e assim a leitura é transformada em ' 1 '. Caso contrário, a leitura é transformada em ' 0 '. 
Desta forma, para o usuário descrever o alvo para o robô, ele indicará, para cada lado do robô, se no local do alvo existe parede ou não. Por exemplo, para descrever o lugar 4 da Figura 8.19, o usuário forneceria ao robô o padrão ' 01 ', indicando que não há parede à esquerda e que existe uma parede à direita do robô. Já para descrever o lugar 3 da Figura 8.19, o usuário forneceria ao robô o padrão '10', indicando que existe parede à direita, mas não há parede à esquerda.

Para facilitar o processo de entrada de dados para o usuário, basta que ele escolha o lugar com um clique do mouse, em cima do lugar alvo desejado. O programa se encarrega de fornecer a descrição binária para o robô.

Dada a descrição do lugar, a mesma será alimentada para a Rede Neural ARTl. A rede irá realizar o processamento nas entradas e, como resultado, uma célula da camada F2 será ativada. Uma vez ativada esta célula, ela irá ativar uma célula no mapa TPM. Esta célula tem valores armazenados em suas conexões que representam coordenadas de localização. Estas coordenadas correspondem ao alvo.

Tendo as coordenadas do alvo, é necessário que o robô determine suas coordenadas atuais. Isto é realizado coletando as leituras atuais recebidas pelos sensores, realizando um pré-processamento (aplicando o limiar de 1,5m) e alimentando estes dados na Rede Neural ART1, da mesma forma como ocorreu para a determinação do alvo. O neurônio ativo na camada F2 da Rede ART1 irá ativar uma célula no mapa TPM, que responderá com as coordenadas que representam a posição atual do robô.

Neste ponto, o robô obtém o ponto inicial e o ponto final de sua jornada. Esta é a contribuição do mecanismo de mapa cognitivo. A partir daí, os pontos inicial e final são fornecidos para um sistema de planejamento de rota.

O sistema de planejamento de rota para o labirinto 7 é muito simples, apenas calcula a distância d a ser percorrida e envia uma requisição para movimentar o robô por $d$ centf́metros ao sistema de navegação de baixo nível, que neste caso é o próprio simulador Saphira. 


\subsection{Considerações Finais}

Esta foi a etapa mais frustrante e demorada do projeto. Muito tempo e esforço foi gasto até se descobrir que a rede VAM não era adequada para as operações que necessitavam ser aprendidas, e outra parcela de tempo foi gasta com um método complicado de cálculo de trigonometria. Isto resultou na necessidade de utilizar mecanismos mais simples que os inicialmente propostos no restante do sistema de navegação.

Redes Neurais foram utilizadas porque os sensores não são confiáveis. Se houvesse um tipo de sensor preciso, ou os atuadores pudessem ser calibrados e mantidos perfeitamente, a Rede Neural seria desnecessária, e as equaçбes trigonométricas poderiam ser aplicadas diretamente. Assim, a Rede Neural do tipo MLP, com sua capacidade de mapeamento não linear, serve para compensar as imperfeiçס̃es dos sensores e atuadores.

Em uma dimensão (para frente e para trás), a posição invariante é dada pela soma da distância atravessada (sensor de trás, medindo a distância do robô ao marco) e da distância estimada (sensor da frente, medindo a distância do robô ao alvo). Esta tarefa foi desempenhada com sucesso pela rede VAM. Para duas dimensర̃es, foi necessário o emprego da Rede Neural do tipo MLP.

Em duas dimensơes, o robô deve estimar o deslocamento de um objeto em relação a um marco, a partir de qualquer ponto do ambiente. Este deslocamento é chamado invariante, porque o deslocamento entre o marco e o alvo permanece o mesmo em termos de ângulo $\mathrm{e}$ distância. Por outro lado, a posição do robô varia quando ele se move e, por isso, a distância entre robô e marco e a distância entre e robô e alvo variam. $O$ importante a observar é que, a partir destes parâmetros variantes, é possível obter a posição invariante do alvo em relação ao marco.

Para que este esquema funcione, é preciso que o robô seja capaz de medir sua distância e ângulo em relação ao marco e sua distância e ângulo em relação ao alvo. Com estes dados, é possível calcular a posição e o ângulo do alvo em relação ao marco (invariante). Além desta capacidade de medição, o robô deverá possuir um mecanismo de reconhecimento de padrões, de modo a identificar o objeto que está localizado no alvo e assim poder realizar a associação entre o objeto e sua localização. A parte de reconhecimento de padrớes ficou a cargo da Rede Neural do tipo ART1. 
Bons resultados foram obtidos com esta abordagem, conforme foi relatado neste Capítulo. O sistema é capaz de realizar as mesmas tarefas que um sistema já construído e, uma vez que aprende o ambiente, nenhum treino adicional é necessário para que o robô siga novas trajetórias no ambiente enquanto procura por um alvo.

No próximo Capítulo, são apresentadas conclusões a respeito do trabalho e são sugeridas algumas áreas para a realização de futuros trabalhos a respeito do tema. 


\section{Conclusão}

O presente trabalho explorou a possibilidade de se utilizar um mecanismo inspirado em mapas cognitivos para a tarefa de navegação em robôs móveis.

O mecanismo de mapa cognitivo proposto neste trabalho é implementado através de Redes Neurais Artificiais, em particular com redes do tipo MLP e ART1.

Ao longo da pesquisa realizada, constatou-se que Redes Neurais do tipo VAM não são adequadas para mapeamentos não lineares em geral. Como um ponto central no mecanismo proposto era justamente a realização deste tipo de mapeamento, o trabalho despendido em pesquisas com a rede VAM foi em vão.

A área de navegação é bastante ampla, no sentido que envolve diversas disciplinas. Por exemplo, os robôs envolvem mecânica, eletrônica e computação. Por sua vez, a interação entre o robô e o ambiente pode ser modelada através da aplicação de Geometria e Trigonometria. Existem muitas formas de se realizar este tipo de modelagem e, infelizmente, a primeira abordagem tentada se mostrou muito complexa, fato que colaborou para o atraso do projeto.

Juntos, os tempos despendidos nas pesquisas da rede VAM e das questões de Trigonometria consumiram meses que estavam inicialmente destinados à pesquisa sobre como um sistema de navegação de alto nível poderia utilizar o mecanismo de mapa cognitivo desenvolvido neste trabalho. Como conseqüência, o mecanismó de navegação permaneceu o mais simples possível, sendo constituído de regras rígidas embutidas no programa de controle, que foi desenvolvido na linguagem Visual $\mathrm{C}+5.0$.

Apesar de todas as dificuldades encontradas, o mecanismo de mapa cognitivo proposto saiu-se bem como fundação de um Sistema de Navegação, conforme mostram os resultados apresentados no Capítulo 8. Visto apenas como módulo, o mecanismo de mapa cognitivo foi bem sucedido, vindo de encontro às expectativas iniciais.

O sistema é flexível, de modo que diversos tipos de sensores podem ser usados. Por isso, é possível utilizar tanto os sensores ultra sônicos quanto informação das rodas (deadreckoning) para estimar a distância percorrida pelo robô.

De fato, a forma mais simples de se criar um mapa cognitivo é através de deadreckoning. Nesta modalidade, inicialmente o robô escolhe um ponto do ambiente para ser um 
marco. Este ponto será marcado como ponto inicial de um sistema de coordenadas locais. Depois o robô se locomove pelo ambiente e um sensor (por exemplo, um encoder) registra seu deslocamento. Ao encontrar os objetos, o robô associa a posição em que ele está com o objeto encontrado. A desvantagem desta estratégia é que o robô deve navegar por todo ambiente a fim de obter a informação de deslocamento.

O sistema de dead-reckoning pode funcionar baseado em diversos tipos de sensores. Embora o mais comum seja o encoder, que mede o deslocamento das rodas, também podem ser empregados sensores ultra sônicos e câmeras, com algoritmos capazes de estimar distância ou equipadas com laser, também com o objetivo de medir distâncias.

Como trabalhos futuros, podem ser propostas explorações do mecanismo de mapa cognitivo em diversos tipos de paradigmas, como o Reativo e o Baseado em Planos, uma vez que ele não apresenta nenhuma restrição para trabalhar apenas em conjunto com sistemas baseados no paradigma Cognitivo.

Outra característica importante que não chegou a ser explorada no presente trabalho é que o mecanismo de mapa cognitivo é capaz de eliminar o erro acumulado pelos sensores. Esta característica funciona da seguinte maneira: Um lugar é a porção do ambiente que pode ser capturada pelos sensores, estando o robô em um dado ponto. Dentro deste lugar, enquanto o robô se movimenta, os erros dos sensores (Ex.: Encoders) vão se acumulando. $O$ mecanismo de mapa cognitivo atribui, para cada artefato reconhecido no ambiente, uma coordenada específica. Esta coordenada é dada em relação a um determinado marco, que é um artefato distintivo que faz parte do lugar. Para eliminar o erro acumulado nos sensores, o robô pode se dirigir a um artefato e ignorar as leituras dos encoders acumuladas. Em seu lugar, pode adotar as coordenadas do artefato.

Estratégia semelhante pode ser adotada se, ao passar de um lugar a outro, o robô se dirigir ao marco associado ao novo lugar e ignorar as leituras acumuladas dos sensores, iniciando uma nova contagem tendo como origem das coordenadas o próprio marco.

A idéia de utilizar uma Rede Neural que realizasse aprendizado on-line precisou ser abandonada por causa das restrições de tempo. Porém, uma modificação bem vinda ao sistema de mapa cognitivo seria a adição de tal rede.

Finalmente, uma extensão interessante é a comparação entre o desempenho de um Sistema de Navegação que utilize o mecanismo de mapa cognitivo proposto neste trabalho com o desempenho de animais ou mesmo seres humanos. Para isso, pode-se, por exemplo, 
implementar um programa de computador que simule os mesmos labirintos apresentados neste trabalho e medir o tempo e padrões de movimentos realizados por pessoas que teriam como tarefa atingir um determinado alvo da mesma forma que o robô. 


\section{Bibliografia}

[1] Amorim, M-A., Stucchi, N.; Viewer- and object-centered mental explorations of an imaged environment are not equivalent; Cognitive Brain Research (5) pp. 229-239; 1997.

[2] Amorim, M-A., Glasauer, S., Corpinot, K., Berthoz, A.; Object Orientation and Location Updating Using Nonvisual Navigation: The Characteristics and Effects of Object-Versus Trajectory-Centered Processing Modes; pp. 193-206; 1996.

[3] Anderson, J.A., Rosenfeld, E.; Neurocomputing - Foundations of Research; Cambridge, MA: MIT Press; 1988.

[4] Bradski, G., Carpenter, G., Grossberg, S.; STORE working memory networks for storage and recall of arbitrary temporal sequences; Biological Cybemetics (71) pp. 469-480; 1994.

[5] Braga, A. P. S., Um Agente Autônomo Baseado em Aprendizagem por Reforço Direcionado à Meta, Dissertação de Mestrado, Escola de Engenharia de São CarlosUniversidade de São Paulo; 1998.

[6] Brooks, R., Stein, L. A., Building Brains for Bodies; AI Memo No. 1439, MIT Artificial Intelligence Laboratory; 1993.

[7] Brooks, R. A.; A Robust Layered Control System for a Mobile Robot; IEEE Journal of Robotics and Automation, RA-2, pp. 14-23, April 1986.

[8] Bullock, D., Grossberg, S., Guenther, F.; A self-organizing neural network model for redundant sensory-motor control, motor equivalence, and tool use; Journal of Cognitive Neuroscience (5): pp. 408-435; 1993.

[9] Burhanpurkar, V.; Design of a Commercial Autonomous Service Robot; In: Instantiating Real-World Agents - Papers from the 1993 AAAI Fall Symposium, pp. 26-33; Menlo Park, CA: AAAI Press; 1993.

[10] Chown, E., Kaplan, S., Kortenkamp, ,D.; Prototypes, Location and Associative Networks (PLAN): Towards a Unified Theory of Cognitive Mapping; Cognitive Science(19) pp. 1-51; 1995.

[11] Deneve, S., Pouget, A.; Neural Basis of Object-Centered Representations; To appear in: Advances in Neural Information Processing Systems, 10. Jordan, M. I., Kearns, M. J., Solla, S. (Eds.); Cambridge, MA: MTT Press, In Press.

[12]Fikes, R. E., Hart, P. E., Nilsson, N. J.; Learning and Executing Generalized Robot Plans; Artificial Intelligence (3) pp. 251-288; 1972.

[13]Freeman, J. A., Skapura D.M.; Neural Networks - Algorithms, Applications and Programming Techniques; Addison-Wesley. 1991.

[14]Fu, K.S., Gonzalez, R.C., Lee, C.S.G.; Robotics - Control, Sensing, Vision and Intelligence; New York: McGraw-Hill; 1987.

[15] Gallant, S. L.; Neural Network Learning and Expert Systems; Cambridge, Mass: MIT Press; 1995.

[16] Gaudiano, P., Grossberg, S.; Vector Associative Maps: Unsupervised Real-Time ErrorBased Learning and Control of Movement Trajectories; Neural Networks (4) pp. 147$183 ; 1991$.

[17] Gaudiano, P., Zalama, E., Chang, C., López Coronado, J.; A model of operant conditioning for adaptive obstacle avoidance; In: Maes, P., Mataric, M.J., Meyer, J., Pollack, J, Wilson, S.W., (Eds.), From Animals to Animats (4) pp. 373-381, Cambridge, MA: MIT Press; 1996. 
[18] Gaudiano, P., Zalama, E., López Coronado, J.; An Unsupervised Neural Network For Low-Level Control of a Mobile Robot: Noise Resistance, Stability and Hardware Implementation; Boston University Technical Report, CAS/CNS-TR-94-019; 1994.

[19] Groover, M.P., Weiss, M., Nagel, R. N., Odrey, N.G.; Robbtica - Tecnologia e Programação; São Paulo: McGraw-Hill; 1988.

[20] Grossberg, S.; Mathematical Psychology and Psychophysiology; Proceedings of the symposium in applied mathematics of the American Mathematical Society and the Society for industrial and applied mathematics; 1981.

[21] Grossberg, S.; Studies of Mind and Brain; Dordercht: D. Reidel Publishing Company; 1982.

[22] Grossberg, S.; Competitive Learning: From Interactive Activation to Adaptive Resonance; Cognitive Science (11) pp. 23-63; 1987.(a)

[23] Grossberg, S.; The Adaptive Brain, Vol. I e II; North Holland: Elsevier; 1987.(b)

[24] Grossberg, S.; Neural Networks and Natural Intelligence; Cambridge, Mass: MIT Press; 1988.

[25] Grossberg, S., Levine, D. S.; Neural dynamics of attentionally modulated Pavlovian conditioning: blocking, interstimulus interval, and secondary reinforcement; Applied Optics 26(23) pp. 5015-5030; 1987.

[26] Guenther, F. H., Bullock, D., Greve, D., Grossberg, S.; Neural representations for sensory-motor control, III: Learning a body-centered representation of $3 D$ target position; Technical Report, Boston University Center for Adaptive Systems; 1992.

[27] Hebb, D.O.; The Organization of Behavior; New York: Wiley; 1949.

[28] Hervey, R. L.; Neural Networks Principles; Englewood Cliffs: Prentice-Hall; 1994.

[29] Honda, 1999; http://www.honda.co.jp/tech/other/robot.html

[30] Horswill, l., Visual Support for Navigation in the Polly System; In: Instantiating RealWorld Agents - Papers from the 1993 AAAI Fall Symposium, pp. 62-67; Menlo Park, CA: AAAI Press; 1993.

[31] James, W.; Psychology (Briefer Course); New York: Holt. Chapter XVI, “Association," pp. 253-279, in: Anderson, J.A., Rosenfeld, E. (Eds.) Neurocomputing - Foundations of Research; Cambridge, MA: MIT Press; 1988.

[32] Jenkins, F.; Practical Requirements for a Domestic Vacuum-Cleaning Robot; In: Instantiating Real-World Agents - Papers from the 1993 AAAI Fall Symposium; pp. 8590; Menlo Park, CA: AAAI Press; 1993.

[33] Jones, J. L., Flynn, A. M.; Mobile Robots: Inspiration to Implementation; A K Peters Ltd; 1993.

[34] Kosslyn, S.M. Image and Brain: The Resolution of the Imagery Debate; Cambridge, Mass: MIT Press; 1996.

[35] Kortenkamp, D.; Applying computational theories of cognitive mapping to mobile robots; In: Instantiating Real-World Agents - Papers from the 1993 AAAI Fall Symposium, pp. 83-89; Menio Park, CA: AAAI Press; 1993.

[36]Kuipers, B.; A Hierarchy of Qualitative Representations for Space; In: Working Papers of the Tenth International Workshop on Qualitative Reasoning about Physical Systems (QR-96); Menlo Park, CA: AAAI Press; 1996.

[37] Kuipers, B.; The Map-Learning Critter; Artificial Intelligence Laboratory Technical Report AI-TR-85-17, University of Texas at Austin; 1985.

[38] Kuipers, B.; The Cognitive Map: Could It Have Been Any Other Way?; In Pick, H. L. and Acredolo, L. P. (Eds.) Spatial Orientation: Theory, Research, and Application. New York: Plenum Press, pp. 345-359; 1983. 
[39] Kuipers, B.; The "Map in the Head" Metaphor; Environment and Behavior 14(2) pp. 202$220 ; 1982$.

[40]Kuipers, B.; On Representing Commonsense Knowledge; In: Findler, N. V. (Ed.) Associative Networks: The Representation and Use of Knowledge by Computers; NY: Academic Press, pp. 393-408; 1979.

[41] Kuipers, B.; Modeling Spatial Knowledge; Cognitive Science (2) pp. 129-153; 1978

[42]Kuipers, B., Byun, Y.; A Robot Exploration and Mapping Strategy Based on a Semantic Hierarchy of Spatial Representations; Journal of Robotics and Autonomous Systems (8) pp. 47-63; 1991.

[43] Kuipers, B., Froom, R., Lee, W., Pierce, D.; The Semantic Hierarchy in Robot Learning; In: Connel, J. \& Mahadevan, S., (Eds.) Robot Learning. Kluwer Academic Publishers, Boston. pp. 141-I70; 1993.

[44] Lynch, K.; The Image of the City; Cambridge, MA: MIT Press; 1960.

[45] Marr, D.; Vision; San Francisco: Freeman; 1982.

[46] Marsh, P.; Robots; Lisboa: Verbo; 1985.

[47] Mataric, M. J.; A Distributed Model for Mobile Robot Environment-Learning and Navigation; MIT Technical Report 1228; 1990.

[48] McClelland, J., Rumelhart, D.; Parallel Distributed Processing vol. 1 and 2; Cambridge, MA: MIT Press; 1986.

[49] Medeiros, A.A.D.; A Survey of Control Architectures for Autonomous Mobile Robots; Journal of the Brazilian Computer Society, Number 3, Volume 4, April, 1998.

[50] Moravec, H. P.; Sensor fusion in certainty grids for mobile robot. AI Magazine, pp. 6174, Summer; 1988.

[51]Nilsson, N.; A Mobile Automaton: An Application of Artificial Intelligence Techniques; In: Proceedings of the IJCAI, pp. 509-520; 1969.

[52] Pierce, D., Kuipers, B.; Map Learning with Uninterpreted Sensors and Effectors; Artificial Intelligence Journal; 1997.

[53]Pierce, D., Kuipers, B.; Learning to Explore and Build Maps; In: Proceedings of the Twelfth National Conference on Artificial Intelligence (AAAI-94); Cambridge, MA: AAAl/MIT Press; 1994.

[54] Rich, E. Knight, K.; Artificial Intelligence; New York: McGraw Hill; 1991.

[55] Sahin, E., Gaudiano, P. Mobile robot range sensing through visual looming, Boston University, Technical Report CAS/CNS-98-010; 1998.

[56] Salant, M. A.; Introdução à Robótica; São Paulo: McGraw-Hill; 1990.

[57] Schmajuk, N., Animal Learning and Cognition : A Neural Network Approach, Cambridge Univ Press; 1997.

[58] Schmajuk, N., Psychology of Robots, Proceedings of IEEE (84) pp. 1553-1561; 1996.

[59] Schmajuk, N., Cognitive Maps, in Arbib, M.A.(Ed.), The Handbook of Brain Theory and Neural Networks, MA: MIT Press, pp. 197-200; 1995.

[60] Schmajuk, N., Thieme, A.D., Purposive behavior and cognitive mapping: a neural network model, Biological Cybernetics (67) pp. 165-174; 1992.

[6I]Slack, M. G.; System Design for End-User Robots: sharing work amongst research programs; In: Instantiating Real-World Agents - Papers from the 1993 AAAI Fall Symposium, pp. 148-152; Menlo Park, CA: AAAI Press; 1993.

[62] Srinivasa, N., Sharma, R; Efficient Learning of VAM-Based Representation of $3 D$ Targets and its Active Vision Applications; Neural Networks, 11(1) pp. 153-171; 1998. 
[63] Tani, J.; Model-Based Learning for Mobile Robot Navigation from the Dynamical Systems Perspective; IEEE Trans. System, Man and Cybernetics Part B, Special Issue on learning autonomous robots 26(3) pp. 421-436; 1996.

[64] Tani. J.; A Dynamical Approach to Represent Cognition of Robots: A view of the Internal Observer; Sony Computer Science Laboratory Inc., Internet: http://www.csl.sony.co.jp/person/tani.html; 1997.

[65]Thurn, S., Bücken, A., Integrating grid-based and topological maps for mobile robot navigation. In Proceedings of the Thirteenth National Conference on Artificial Intelligence, Menlo Park, August 1996. AAAI Press / MIT Press.

[66] Thurn, S., Bücken, A., Burgard, W., Fox, D., Fröhlinghaus, T., Henning, D., Hofmann, T., Krell, M., Schmidt, T.; Map Learning and High-Speed Navigation in RHINO; In: Kortenkamp, D., Bonasso, R. P., Murphy, R. R. (Eds.); Al-Based Mobile Robots: Case studies of successful robot systems; MIT Press.

[67]Tversky, B.; Cognitive Maps, Cognitive Collages and Spatial Mental Models; In: Spatial Information Theory. A Theoretical Basis for GIS. European Conference, COSIT '93 Proceedings, pp. 14-24; 1993.

[68]Ulrich, I., Mondada, F., Nocoud, J.-D.; Autonomous Vacuum Cleaner; Laboratory of Microcomputing, Swiss Federal Institute of Technology. Internet: http://ai.eecs.umich.edu/people/iwan/index.html; outubro 1997.

[69] Winston, P.H.; Artificial Intelligence; Addison-Wesley; 1984.

[70] Yamamoto, M.; "SOZZY:" A Hormone-Driven Autonomous Vacuum Cleaner; In: Instantiating Real-World Agents - Papers from the 1993 AAAI Fall Symposium, pp. 116-125; Menlo Park, CA: AAAI Press; 1993.

[71] Yeap. W. K., Towards a Computational Theory of Cognitive Maps; Artificial Intelligence (34) pp. 297-360; 1988.

[72]Zalama, E., Gaudiano, P., Coronado, J. L.; A Real - Time, Unsupervised Neural Network For The Low - Level Control of a Mobile Robot in a Nonstationary Environment; Neural Networks, 8(I), pp. 103-123; 1995. 


\section{Apêndice A - Um método para calcular o ângulo invariante}

Neste apêndice, é apresentado o primeiro método pesquisado para a obtenção do ângulo invariante entre o marco e o alvo (o ângulo $\theta$ ).

Para este cálculo, utilizou-se a Equação A.1, que é apresentada na Figura A.l, juntamente com a representação gráfica de seu significado. Esta equação é baseada em conceitos de Trigonometria.

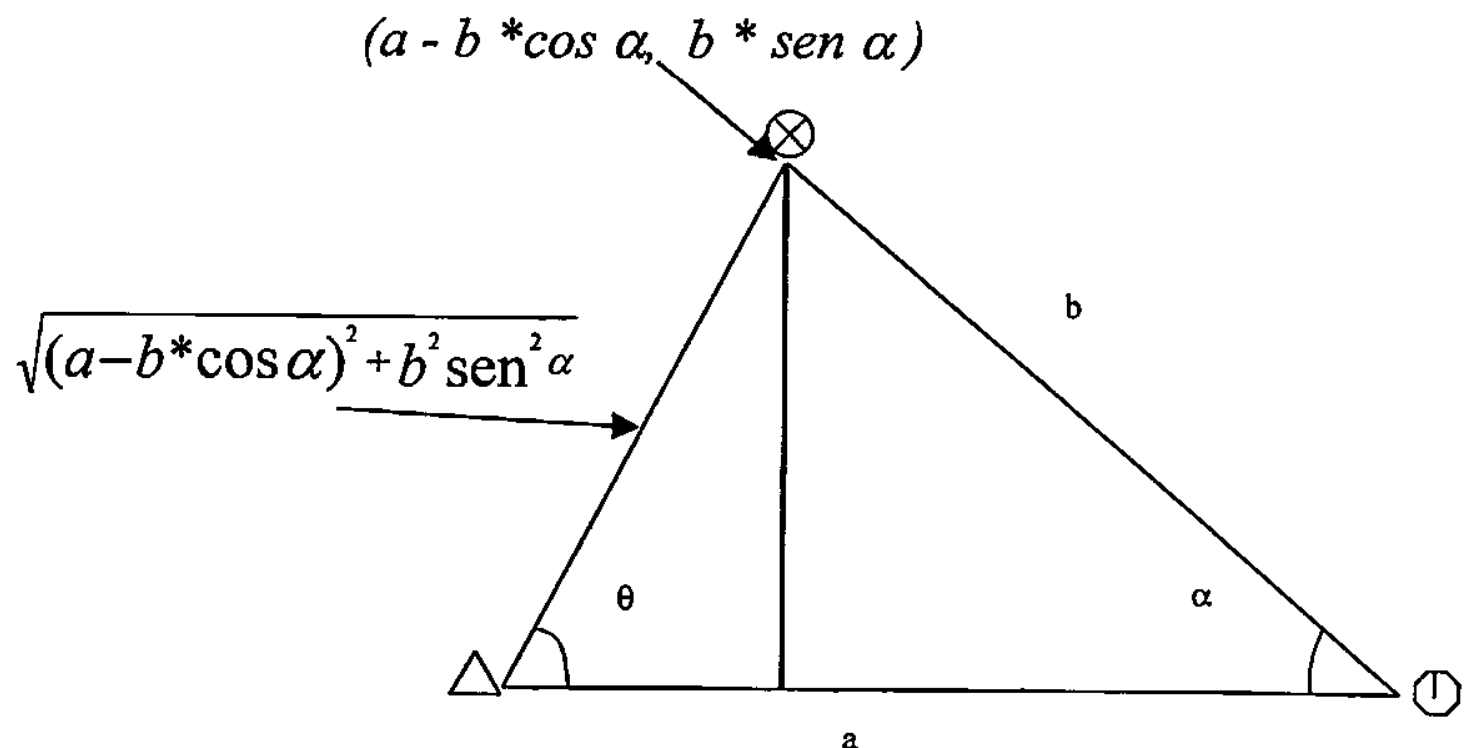

$\operatorname{tg} \theta=\frac{b^{*} \operatorname{sen} \alpha}{a-b^{*} \cos \alpha}$

Figura A.1 - Equação para encontrar o ângulo entre o marco e o alvo (ângulo $\theta$ ).

$O$ robô estará localizado no vértice $\alpha$.

A listagem A.1 apresenta uma função em linguagem C que implementa esta equação nas simulações realizadas. 
Listagem A.1: Uma implementação em C da Equação A.1

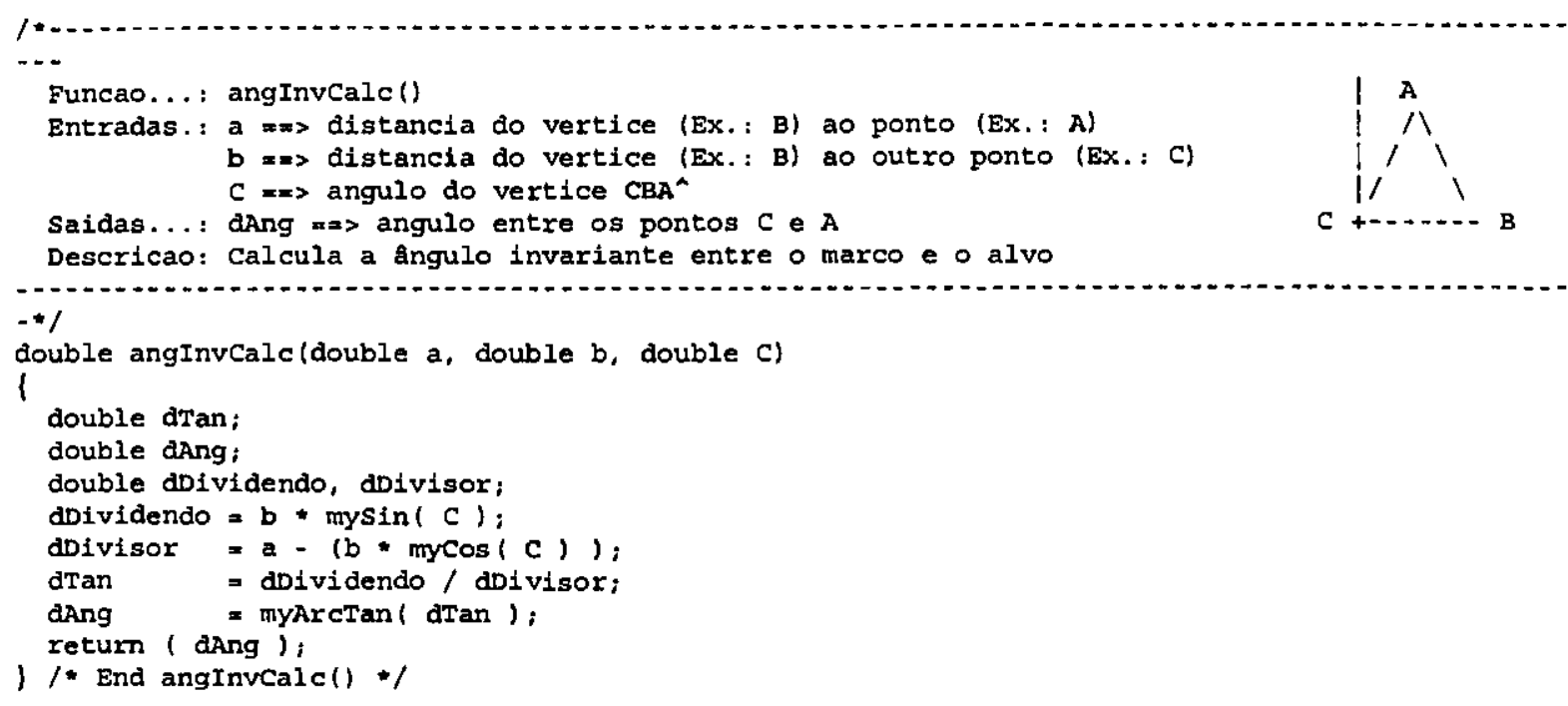

O problema com a implementação da Equação A.1 no robô Pioneer I está na obtenção de diferentes resultados para a mesma equação. $O$ resultado obtido depende das diversas orientaç̃es do marco e do alvo. Nos experimentos realizados, a orientação do robô foi mantida sempre fixa, como se ele estivesse "olhando para frente".

A abordagem descrita neste Apêndice procura corrigir as variações nos resultados obtidos, contornando o fato do robô estar em uma orientação fixa.

Ao utilizar a Equação A.1, não faz a mínima diferença a orientação do marco, a do artefato, nem do robô. Ela funciona da mesma forma seja qual for a orientação. Por que, então, introduzir mais complexidade levando em consideração a orientação do robô? Basicamente, para 1) Compensar os casos em que o robô não está na mesma linha horizontal que o marco e 2) Compatibilizar a notação do Saphira com a notação da equação.

Neste ponto, aparecem duas questões sobre a compatibilidade da equação com a implementação utilizando as funções disponíveis na linguagem de programação. A primeira é sobre a compatibilidade das medidas e a segunda sobre a localização relativa entre o robô e o marco. Estas questões serão analisadas a seguir.

A primeira questão é: Como descobrir o ângulo $\alpha$ que será enviado como parâmetro para a Equação A.1? O robô Pioneer I vem com uma biblioteca de funções chamada Saphira. Entre estas funções, estão aquelas que retornam o ângulo formado entre o robô e um artefato. O sistema de coordenadas local do robô utilizado para retornar estas medidas é apresentado na Figura A.2. 
Quando um artefato está localizado exatamente na frente do robô, a função sfDistPhi() da API Saphira fornece como resultado $0^{\circ}$.

Quando o artefato está localizado exatamente na frente do marco, a Equação A.l produz como resultado $90^{\circ}$.

Assim, se o robô está localizado em cima do marco e de frente para o artefato, a função de ângulo do robô dará como resultado $0^{\circ}$ enquanto que a Equação A.1 resultará em $90^{\circ}$.

A programação se torna mais simples se os dados forem compativeis com a notação do Saphira. Para a conversão entre o resultado da Equação A.1 e a notação interna, pode-se utilizar a seguinte equação:

angInvariante $=$ angCalculado + fatorDeCorrecao

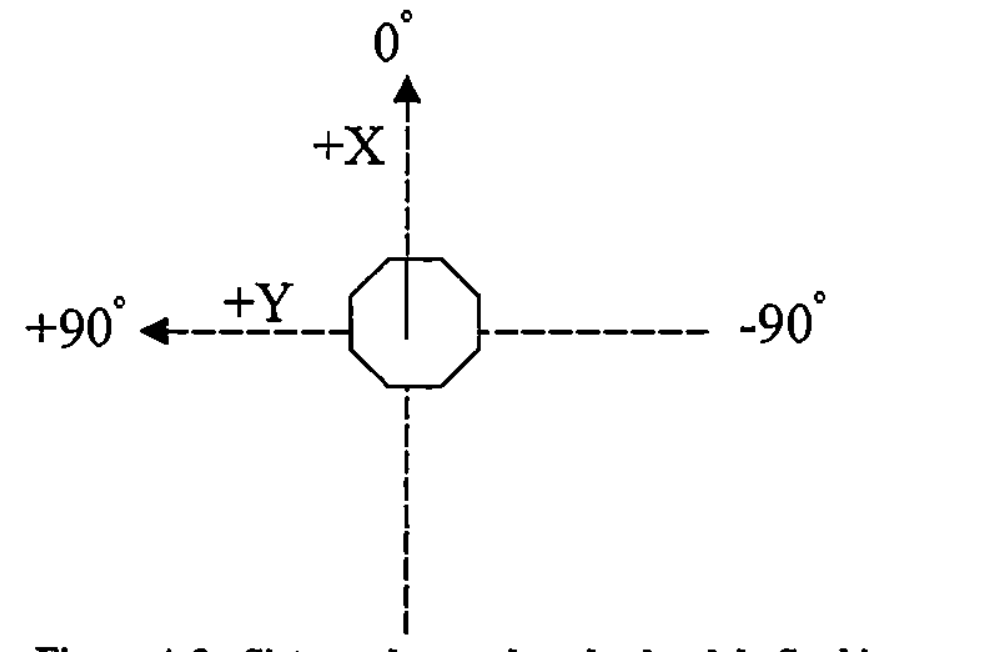

Figura A.2 - Sistema de coordenadas local do Saphira.

Nesta equação, o fatorDeCorreção corresponde a um valor que compensa a diferença entre as notações. $\mathrm{O}$ angCalculado é o ângulo calculado pela Equação A.1. Finalmente, angInvariante é o ângulo entre o marco e o artefato, expresso na mesma notação utilizada pela biblioteca de funções Saphira.

A segunda questão a ser tratada vem da constatação de que a Equação A.1 assume que o robô estará localizado na mesma linha horizontal que o marco (estariam ambos na base do triângulo na Figura A.1). Quando este pressuposto é atendido, a equação fornece resultados invariantes para qualquer distância entre o marco e o robô. Ver Figura A.3. 

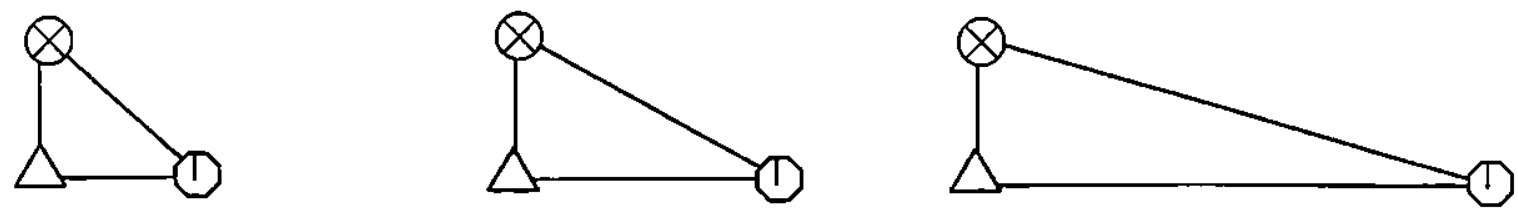

Figura A.3 - Situações em que a Equação A.1 funciona sem modificações. Observar que o marco e o robô estão sempre sobre a mesma linha horizontal, perpendicular a linha reta formada entre o marco e o artefato.

Na maior parte das vezes, entretanto, esta condição não será atendida. Por exemplo, na Figura A.4, pode-se observar uma situação em que o robô não está na mesma linha horizontal que o marco. Ele está localizado mais acima desta linha imaginária, exatamente pela diferença do ângulo beta. Por isso, é necessário uma forma de compensar estes deslocamentos.

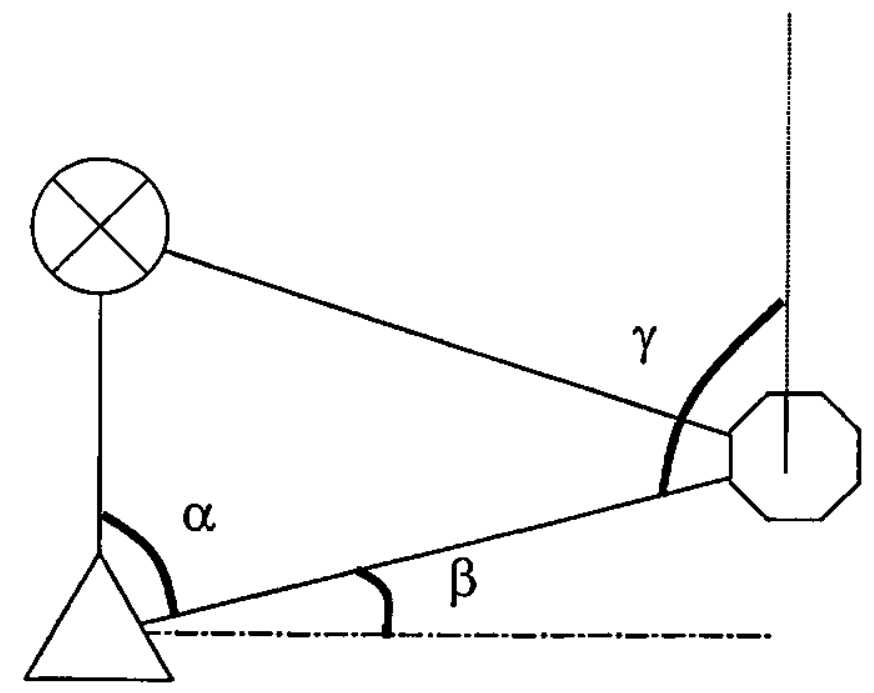

Figura A.4 - Deslocamento entre marco e robô.

Quando o marco e o robô não estão sobre a mesma linha horizontal, o deslocamento entre eles (deslocamento beta) deve ser levado em conta para o cálculo do ângulo invariante entre o marco e o alvo.

$O$ valor do ângulo gama pode ser obtido através da chamada à função sfDistPhi $O$ da API Saphira. Neste exemplo, portanto, o ângulo beta será igual ao ângulo gama $-90^{\circ}$.

Assim, para a obtenção do ângulo invariante geral, isto é, que leve em conta os possiveis deslocamentos do robô em relação ao marco horizontalmente (deslocamento beta), deve-se utilizar as seguintes equações:

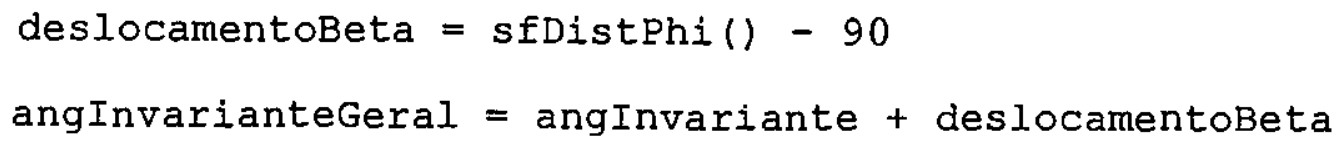


Nestas equações, deslocamentoBeta representa o deslocamento do robô em relação à linha horizontal imaginária, na qual a equação espera que ele esteja localizado. A variável angInvarianteGeral representa o ângulo do marco em relação ao artefato, que é invariante em relação a posição ocupada pelo robô.

O algoritmo que implementa estas equações é dado por:

1. Calcular a distancia do robó ao marco

2. Calcular a distáncia do Robó ao artefato

3. Calcular o angulo cujos vértices são o Robô, o Marco e o Artefato

4. Calcular a distancia invariante do marco ao Artefato

5. Calcular o angulo invariante do marco ao artefato, dada a distancia do Robô ao marco, do Robô ao artefato e o angulo cujos vertices são o Robo, o Marco o o Artefato

Infelizmente, para outras configurações, a equação tem que ser modificada. Estas modificações ocorrem devido à orientação do robô e ao tipo de ângulo retornado na leitura.

Estas modificações afetarão o procedimento do passo 3 do algoritmo. A Figura A.5 mostra exemplos de como a configuração espacial afeta o código que implementa o passo 3 do algoritmo.
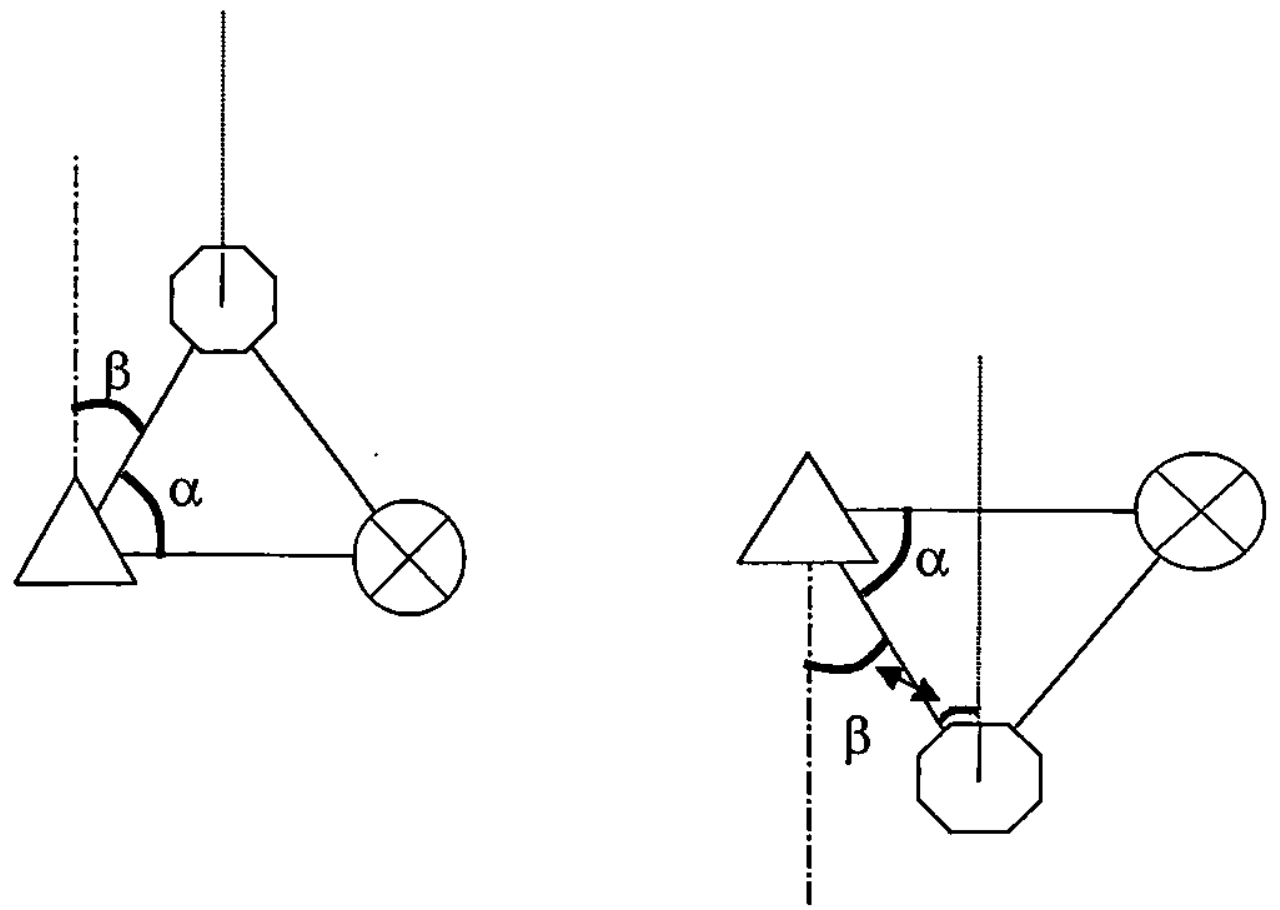

//7//// Artefato para Direita $/ / / 7 / 7 /$

fAngRoboMarco $=$ sfPointPhi ( pMarco);

$\mathrm{XX}=(180-($ fAngRoboMarco $>0$ ? fAngRoboMarco

: -fAngRoboMaxco) ) (EAngRoboMarco > 0 ? 2 :

$-1)$;

fFatorDeCorrecao $=-180$;

/7///// Artefato para Direita $/ / / / / / /$

fAngRoboMarco $=$ sfPointPhi $($ pMarco $) ;$

$\mathrm{XX}$ - fangRoboMarco;

fFatorDecorrecao $=-180$,

fDeslocamentoBeta $=\mathrm{xx} ; / /$ Robô em baixo 

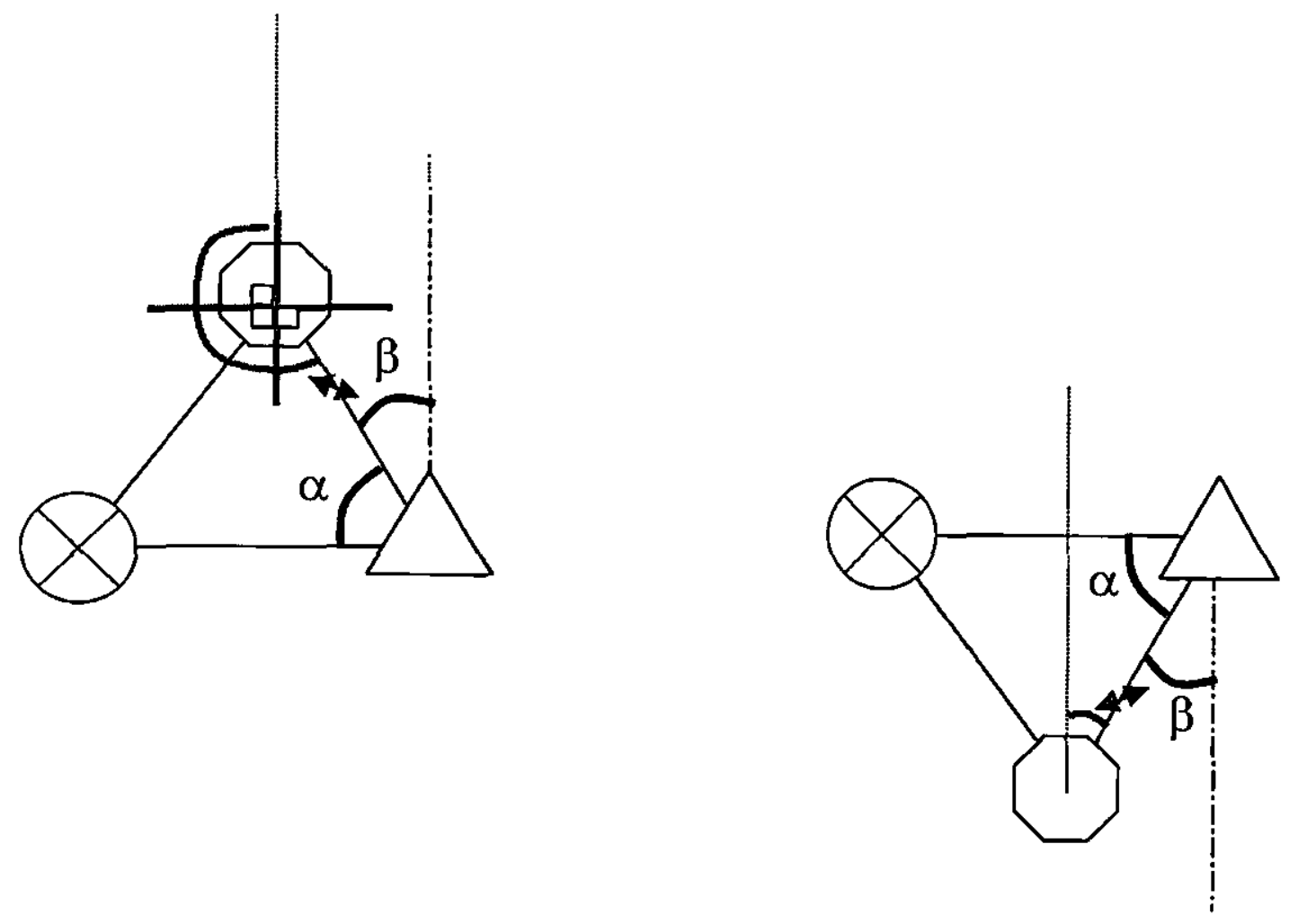

/I/T// Artefato para ssquerda ///T/// fAngRoboMarcor sfNormangle (sf PointPhi (pMarco)); $\mathrm{XX}=$ fAngRoboMarco;

fFatorDeCorrecao $=0$;

fDeslocamentoBeta $=\mathrm{XX}-180 ; / /$ Robs em cima

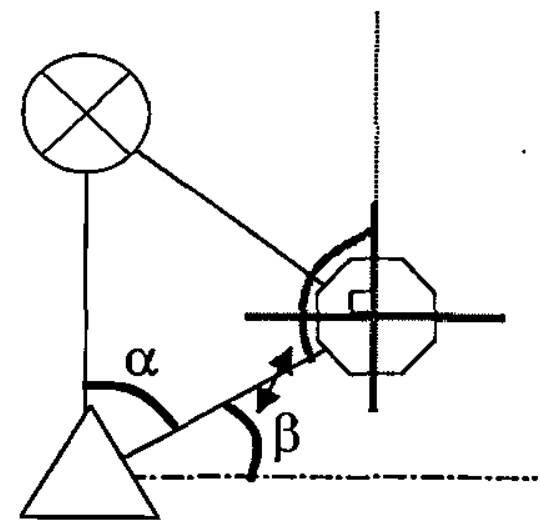

////// Artefato para Esquerda $/ / / / / / /$ fAngRoboMarco $=$ sfPointphi $($ pMarco $)$; $\mathbf{x X}=$ fAngRoboMarco;

fFatorDeCorrecao $=0 ;$

fDeslocamentoBeta $=-x x ; / /$ Robô em baixo
//1/7/ Artefato para Frente $/ / 1 / 77 /$

$\mathrm{XX}$ = sfNormangle ( sfpointPhi ( pMarco) ) ;

fFatorDeCorrecao $=-90$;

fDeslocamentoBeta $=\mathrm{XX}-90 ; / /$ Rob8 a Direita

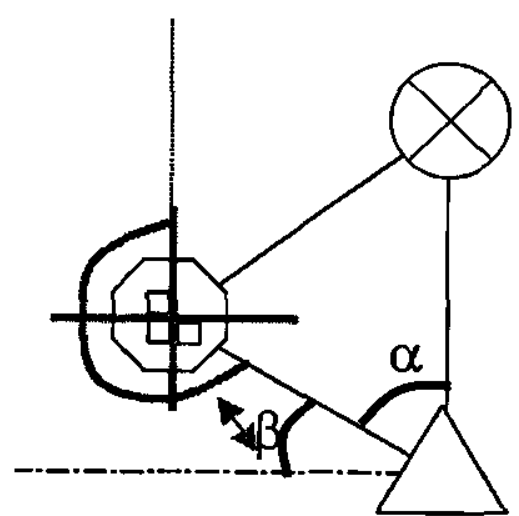

/1/7// Artefato para Frente $/ 17 / 1 / 1$

$x x$ - sfNormangle ( sfPointPhi( pMarco) );

fFatorDecorrecao = -90 ;

fDeslocamentoBeta $=270-\mathrm{xx}_{i} / /$ Robo a Bsquerda 

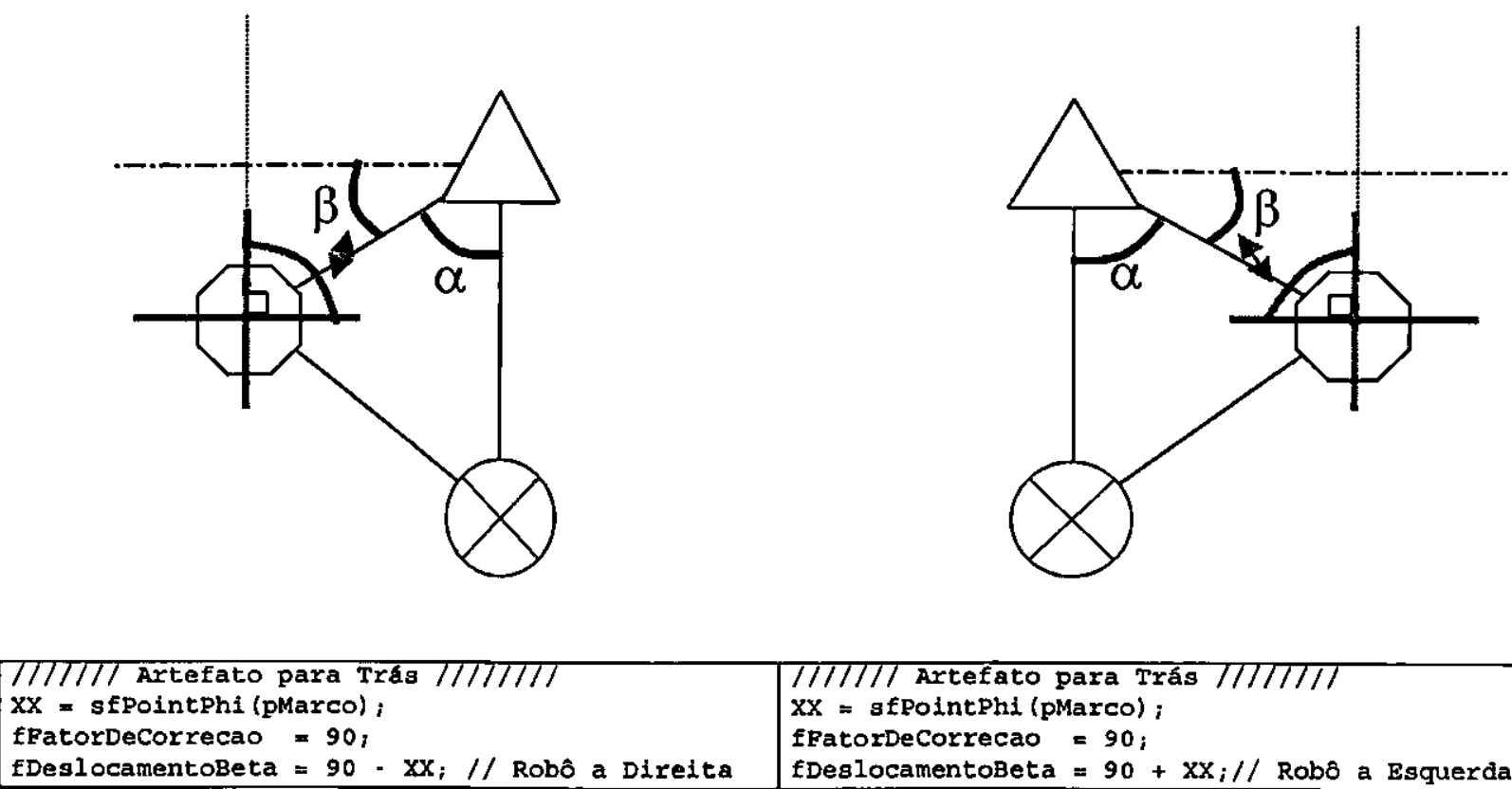

Figura A.5 - Configuraçōes entre o robô, o marco e artefato.

Juntamente com os respectivos trechos de código necessários para realizar os cálculos requeridos.

O trecho de programa a ser aplicado depende da configuração entre o robô, o marco e o artefato. Esta configuração é determinada através de chamadas à API Saphira. Após o qual o trecho a ser aplicado deve ser escolhido. Esta seleção inicialmente foi feita considerando-se a posição do robô em relação tanto ao marco quanto ao alvo. Esta posição poderia ser: acima, abaixo, a esquerda e a direita.

Em cada um destes quatro casos, o robô poderia estar localizado acima ou abaixo de uma linha unindo o marco e o alvo. Infelizmente, este esquema de seleção de trechos de programa falha nas situações mostradas na Figura A.6, porque a classificação discrimina o suficiente, e portanto são necessários refinamentos.

Na Figura A.6, o robô está a esquerda tanto do marco quanto do artefato, e o ângulo do robô ao marco é menor que o ângulo do robô ao artefato. Por isso, o programa executa o mesmo procedimento para os dois casos, que na realidade necessitam de dois procedimentos separados. 

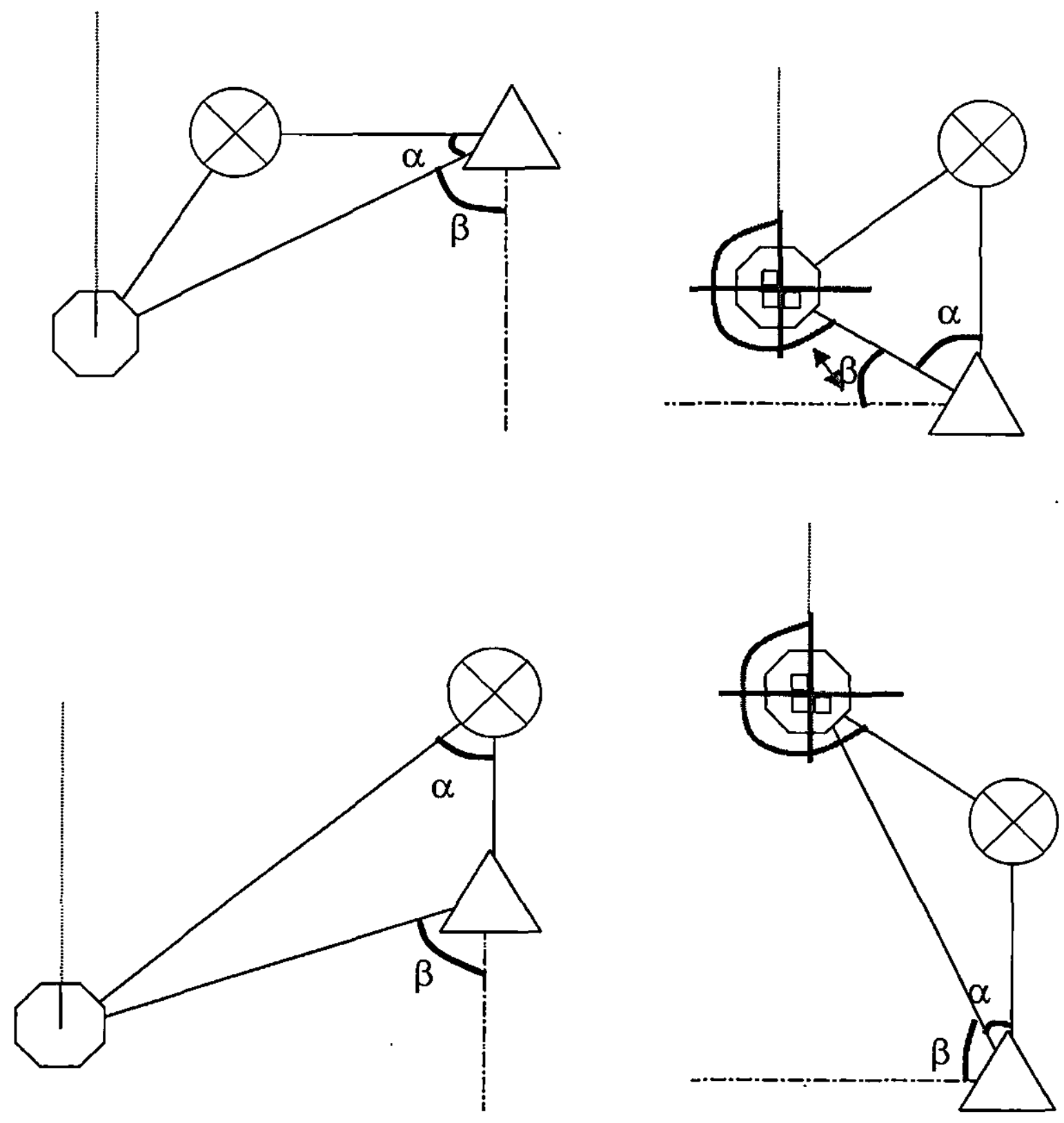

Figura A.6 - O primeiro teste de discriminação.

No primeiro teste para identificar as configurações classifica ambas as situações como idênticas, mas na realidade cada uma requer um método de cálculo distinto.

Ao se constatar a complexidade crescente exigida para se diferenciar as diversas situaçōes, esta abordagem foi abandonada em favor daquela apresentada no Capítulo 8. 